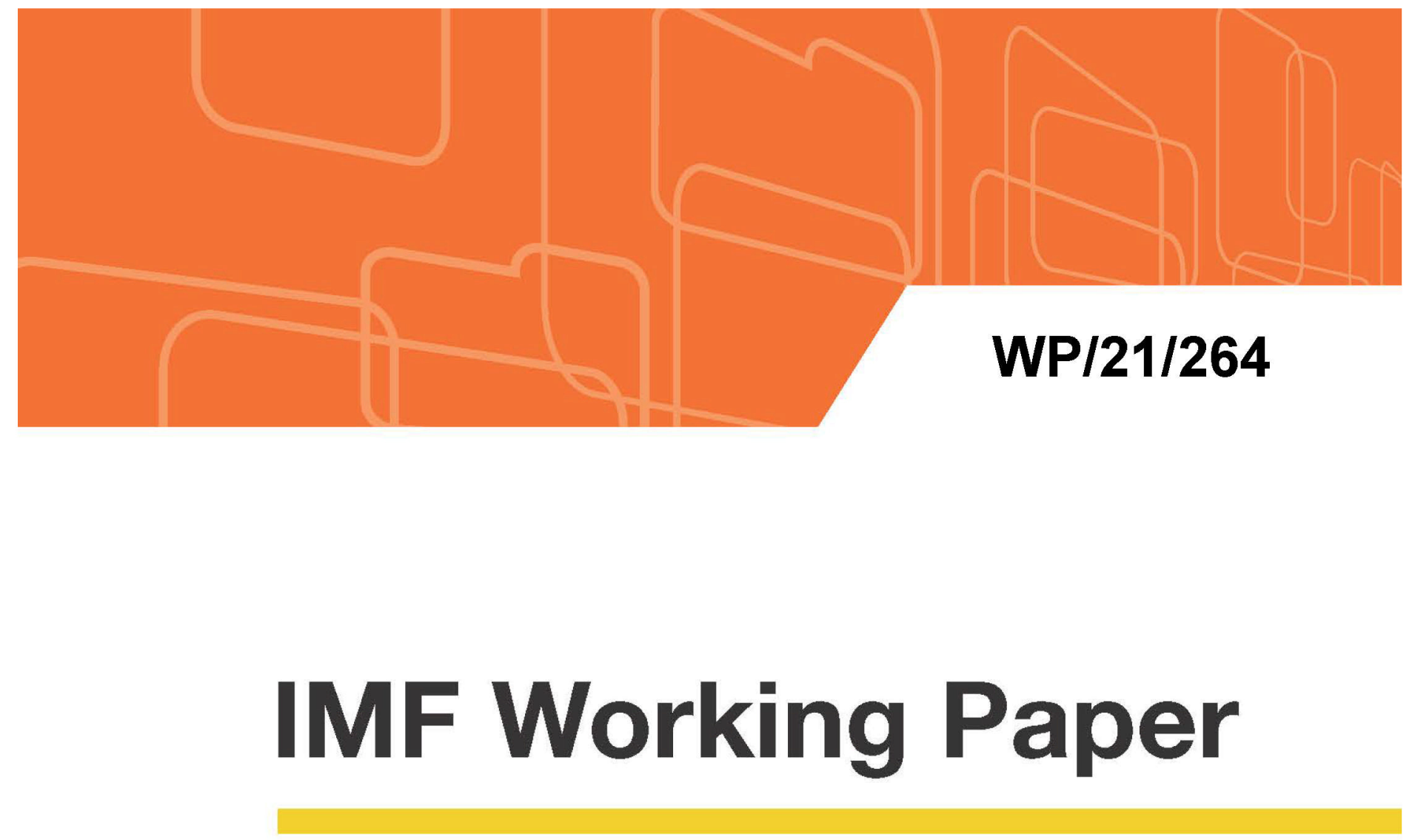

\title{
Commercial Real Estate and Macrofinancial Stability During COVID-19
}

by Andrea Deghi, Junghwan Mok, and Tomohiro Tsuruga

IMF Working Papers describe research in progress by the author(s) and are published to elicit comments and to encourage debate. The views expressed in IMF Working Papers are those of the author(s) and do not necessarily represent the views of the IMF, its Executive Board, or IMF management. 
IMF Working Paper

Monetary and Capital Markets Department

Commercial Real Estate and Macrofinancial Stability During COVID-19

Prepared by Andrea Deghi, Junghwan Mok, and Tomohiro Tsuruga *

Authorized for distribution by Mahvash Qureshi

November 2021

IMF Working Papers describe research in progress by the author(s) and are published to elicit comments and to encourage debate. The views expressed in IMF Working Papers are those of the author(s) and do not necessarily represent the views of the IMF, its Executive Board, or IMF management.

\begin{abstract}
The COVID-19 pandemic crisis has severely shocked the commercial real estate (CRE) sector, which could have important implications for macro-financial stability going forward because of the large size of the sector and its strong interconnectedness with the real economy. Using a novel methodology, this paper quantifies vulnerabilities in the CRE sector and analyzes policy tools available to mitigate related risks. The analysis shows that CRE prices were overvalued in several major advanced economies in 2020:Q1. It also shows that such price misalignments increase the likelihood of future price corrections and exacerbate downside risks to future GDP growth. While the path of recovery in the sector will depend inherently on the pace of overall economic recovery and the structural shifts induced by the pandemic, easy financial conditions may contribute to an increase in financial vulnerabilities and persistent price misalignment. Macroprudential policy can, however, be effective in curbing the financial stability risks posed by the CRE sector.
\end{abstract}

JEL Classification Numbers: E51, E52, E58, G32, H81

Keywords: Commercial Real Estate; Asset Prices; Growth-at-Risk; Panel Quantile Regression; Macroprudential Policy

\footnotetext{
\$Emails: adeghi@imf.org; jmok@imf.org; ttsuruga@imf.org. The authors are very grateful for comments by Tobias Adrian, Salih Fendoglu, Fabio Natalucci, Mahvash Qureshi, Jérôme Vandenbussche, Tony Yezer and seminar participants at the International Monetary Fund; Federal Reserve Bank [of New York?]; George Washington University; Hong Kong Monetary Authority; Institute for International Economic Policy, Joint Vienna Institute and the Bank of Korea. Ken (Zhi) Gan and Oksana Khadarina provided outstanding research assistance.
} 


\section{Contents}

Abstract __ $\underline{2}$

I. Introduction _— $\underline{4}$

II. Market Developments Before and During the COVID-19 Pandemic Crisis ___ $\underline{8}$

A. Data Description___ $\underline{8}$

B. Dynamics in Commercial Real Estate Financial Metrics over the Past Two Decades_즈

C. CRE Market Disruptions during the COVID-19 Pandemic Crisis __ $\underline{9}$

D. Comparison with Previous CRE Market Downturns__ 11

III. CRE Valuation and Price Misalignment

A. A Structural Model for the Price-to-Net-Operating-Income Ratio _ 12

B. The Implications of Structural Shifts in Demand for CRE Valuations __ 16

C. The Effect of CRE Price Misalignment on Downside Risks to CRE Price Growth _ 18

IV. CRE Price Misalignment and Macrofinancial Stability __ 20

V. Macroprudential Policy Effects on Commercial Real Estate Prices __ 25

VI. Conclusion __ 29

References__ $\underline{30}$

Tables $\underline{32}$

Annexes 41

Annex 1. Data Description and Sources $\underline{41}$

Annex 2. Commercial Real Estate Prices and Fundamentals__ $\underline{42}$

Annex 3. Robustness analysis $\underline{45}$

Annex 4. Macroprudential Policies and Downside Risks to CRE Prices 


\section{INTRODUCTION}

The commercial real estate (CRE) sector has been severely affected by the COVID-19 crisis. $^{1}$ Commercial property transaction volumes and prices plummeted globally in the second quarter of 2020 as containment measures taken in response to the pandemic adversely affected economic activity and reduced the demand for commercial property. Some markets, especially in Asia, rapidly recovered from the initial shock, but protracted social distancing restrictions continued to hold back occupier demand in various economies and contributed to an increasing divergence in CRE prices across regions and CRE segments (such as retail, office buildings, industrial, and multifamily buildings).

Beyond the near-term impact, the pandemic has further exacerbated preexisting adverse structural trends in some segments of the market. This is particularly true for the retail segment, where the demand for traditional brick-and-mortar retail had been gradually eroding even before the pandemic as consumers shifted increasingly toward e-commerce. The COVID-19 shock may have also led to persistent adverse effects on the demand for offices and hotels, as businesses adopt more liberal work-from-home policies and substitute online meetings for large in-person gatherings. These trends suggest that the CRE sector might still face challenges-especially for some segments-in the longer term.

A sustained deterioration in the CRE market could affect financial stability. The CRE sector is large, its funding is concentrated, and increasingly relies on leveraged non-bank investors and cross-border capital flows. Historically, the CRE sector has been a source and amplifier of adverse macro-financial shocks - for example, during the global financial crisis, a disorderly adjustment in CRE prices contributed to financial stress (Olszewski 2013; ESRB 2015). More recently before the onset of the COVID-19 pandemic, several countries had been experiencing a combination of double-digit price growth that led to peak price levels and all-time low yields, which raised concerns about overvaluation of CRE prices.

Against this backdrop, this paper analyzes vulnerabilities in CRE markets across 23 advanced economies and 7 emerging market economies by developing a novel framework to assess potential misalignments between observed CRE prices and the fair-value implied by economic fundamentals. We then assess the extent to which CRE price misalignments increase the potential for future price corrections and affect macro-financial stability by amplifying downside risks to GDP growth. Finally, we assess the effectiveness of macroprudential policy actions in mitigating the risk stemming from the CRE sector.

Our paper makes several contributions to the literature. First, we propose an original methodology to quantify the extent to which CRE prices reflect macroeconomic fundamentals (that is, fair values) - and use it to assess the extent of CRE price misalignment over the years, as well as the potential impact of a persistent decline in CRE demand going forward. We model fair value as a

${ }^{1}$ For data availability reasons, the chapter generally considers the CRE sector to include property owned for the primary purpose of benefitting from investment returns (which includes the multifamily segment), as distinct from owner-occupied and noninvestment leased real estate. The size of the latter can be significant in some economies (ESRB 2018). 
function of the expected income of the commercial property and the return of holding the property itself, building on the present-value relationship of Campbell and Shiller (1989). As standard in the literature, the expected return on CRE properties stipulates that investors require risk compensation for exposure to the overall property stock market. Our preferred risk model further adds other macroeconomic factors that could affect CRE valuations such as output gap, inflation and money supply. Based on the model predictions, we determine the misalignment of market valuations as of 2020:Q1 from the fair value implied by economic fundamentals, thus providing a measure of overvaluation that is of a more structural nature than commonly used measures such as nominal capitalization rates.

Our model estimates suggest that CRE prices are associated with movements in market risk premiums, the price and nonprice terms of financing, and unconventional monetary policy (as measured by broad money-to-output ratio). During the peak of the COVID-19 pandemic, our model shows signs of overvaluation, as actual prices did not fall as much as model-based estimated implied. While prices have rebounded somewhat in the last months of 2020 as social distancing measures have eased and economic activity has gained momentum, the unprecedented nature of the COVID-19 shocks is a source of significant uncertainty in the fair value estimates.

CRE price overvaluation could imply downward pressure on CRE prices, especially if structural shifts toward e-commerce and teleworking continue to accelerate. Since the economic recovery is very heterogeneous across and within many economies, accurately forecasting the magnitude of the shifts in consumer preferences and corporate policies and their impact on CRE valuations is extremely challenging. Acknowledging such difficulties, we attempt to examine the effect of a shift in CRE demand on fair prices through a scenario analysis. To this aim, the model is extended for a more restricted group of economies with data availability to incorporate vacancy rates. We then shock the model using a sustained increase in vacancy rates to proxy for a permanent shock to CRE-specific demand and measure the effect on CRE fair value. While the size of the impact varies across economies, a permanent increase in the vacancy rate of 5 percentage points would result in a median drop in fair values of about 15 percent after five years.

The second contribution of the paper is to show that large CRE price misalignments forecast downside risks to economic growth and serve as a leading indicator of financial stability risks. To identify the potential impact of shocks to CRE prices on macro-financial stability, we evaluate the effect of CRE price misalignment on the downside risk to GDP growth using a panel quantile model. Overall, an increase in commercial real estate price misalignment is associated with an increase in GDP downside risk-defined as the range of most severe GDP growth outcomes. Quantitatively, a 50-basis-point increase in the misalignment measure (corresponding to one standard deviation) could raise downside risks to GDP growth (cumulatively)by 1.4 percentage points over four quarters and 2.5 percentage points over 12 quarters.

The presence of underlying financial vulnerabilities in the economy amplifies the effects of CRE misalignment on GDP growth. A first relevant vulnerability stems from the financial (or balance sheet) strength of the borrowers and lenders in the commercial real estate market (such as the 
extent of their leverage or the maturity mismatch of their assets and liabilities), which can create a feedback loop between credit growth and asset prices Similarly, a strong reliance on cross-border flows can amplify boom-bust cycles by inflating prices by more than is justified by economic fundamentals. ${ }^{2}$ In our analysis we thus find that the effect of CRE price misalignments on future downside risks to growth is more pronounced in economies with higher financial leverage or with surging CRE cross-border capital inflows.

Finally, given the potential threat of CRE shocks to macro-financial stability, we analyze the role of macroprudential policies in preventing the buildup of future CRE-related vulnerabilities. While other studies have analyzed the effect of different macroprudential policies on CRE lending, we assess the impact of macroprudential policies in limiting the downside risk in CRE price growth. Specifically, we develop a CRE prices-at-risk model that includes changes in CRE-related macroprudential policy measures, such as limits on the loan-to-value ratio, debt-service-coverage ratio, and risk-weights. We find that a targeted tightening measure reduces downside risks to CRE prices by 2.5 percentage points over 8 quarters on average. We also find that the impact of CRErelated policy measures is more long-lasting when these measures are introduced during the early build-up phase of CRE price misalignment.

Our paper is related to several strands of research. First, several authors have estimated structural models derived from theoretical capitalization rate ("cap rate") models to investigate property price dynamics (Hendershott and MacGregor 2005; Chichernea et al. 2008). ${ }^{3}$ For example, Clayton and others (2009) use an error correction model (ECM) to capture both long-run and short-run cap rate dynamics. Campbell, Davis, Gallin, and Martin (2009) were the first to apply the present value model to residential real estate. Similarly, Van Nieuwerburgh (2019) introduces a parsimonious model for the expected return on REITS which stipulates that investors require risk compensation for exposure to the overall property market, capturing business cycle and interest rate risks.

Overall, these papers offer useful empirical characterizations of the dynamics of residential real estate valuations and provide a solid foundation on which additional research can build. However, their models do not consider directly in their pricing the impact of unconventional monetary policy and capital flows in real estate markets, despite real estate practitioners attribute a large role to the "wall of capital" and the related liquidity that has permeated many markets in the last decade (Cushman and Wakefield, 2016; IPF, 2017). By including such factors, our work builds on the previous literature and provides a more general framework to gauge commercial real estate valuation.

\footnotetext{
${ }^{2}$ For example, domestic CRE markets may become more synchronized with global CRE cycles when international investors chase yields across countries.

${ }^{3}$ The capitalization rate is used to indicate the rate of return that is expected to be generated on a real estate investment property. Capitalization rate is calculated by dividing a property's net operating income by the current market value.
} 
We also contribute to the literature analyzing the impact of the COVID-19 crisis on real estate markets. For instance, Brueckner, Kahn, and Lin (2021) examine changes in residential valuations with a focus on the spatial equilibrium implications of working from home across cities. Davis and others (2021) study the effect of working from home on residential house prices. While most of these studies focus on US residential house prices, our paper sheds light on the impact of the pandemic crisis on CRE price misalignment and the possible long-term impact of structural changes in CRE demand on fair values.

Importantly, our study is also linked to the literature assessing the real and financial stability implications of changes in CRE prices. CRE price corrections have indeed played a large role in recent bank failures as delinquency rates on CRE loans increased more during the crisis than delinquency rates on home mortgages. Ellis and Naughtin (2010) also argue that CRE property developments have historically posed a greater risk to financial institutions' balance sheets than housing and mortgage markets. ${ }^{4}$ Similarly, Fendoglu (2021) finds that US banks have sizable exposures to the CRE sector that could pose financial stability risks, especially in the small and medium-sized bank sector. With regard to impact on the real economy, Chaney et al. (2012) incorporate the fact that firms use CRE as collateral for lending and conclude that decreasing real estate values can have a significant impact on aggregate investment. Taking inspiration from a recent growing literature documenting key factors affecting the future distribution of GDP growth (Adrian and others, 2018; Adrian and others, 2019; Barajas and others, 2021; Brandao-Marques and others, 2019; Deghi and others, 2020), we are the first to document how CRE price misalignment affect an economy's tail risk.

Finally, we inform the discussion on the optimal response of policy makers to the build-up of vulnerabilities in the sector. Most work in this area focuses on the effect on CRE lending. Panagopoulos and Vlamis (2009) highlight poor regulation within the banking system during the pre-GFC period as a key issue and conclude that banks needed to apply tighter lending standards to ensure prudent lending practices. Duca and Ling (2020) show that the tightening of effective capital requirements on commercial mortgage-backed securities in the United States following the Dodd-Frank Act helped to limit asset price booms by preventing sharp declines in commercial real estate risk premiums in the mid-2000s. Bassett and Marsh (2017) find that the 2006 US commercial real estate lending guidance for banks with a high concentration of such loans reduced commercial real estate lending. Our results complement these findings by showing how macroprudential policies can lower the downside risk in the CRE price growth distribution.

The paper is organized as follows: Section II examines major global trends in CRE prices, transaction volumes and capitalization rates at the aggregate level in the last two decades and during the recent COVID-19 pandemic crisis. Section III provides the analytical framework to evaluate CRE valuations and gauges the degree of divergence between observed prices and values implied by fundamentals, i.e., CRE price misalignment. Section IV examines the macrofinancial effects of CRE price misalignment. Section V discusses the impact of macroprudential policies on

${ }^{4}$ Shibut and Singer (2015) add evidence for the riskiness of lending for CRE project development, estimating that such CRE loans had higher loss given default (LGD) rates than other types of loans, and longer workout periods. 
the downside risk to CRE prices. Section VI concludes and is followed by a data annex (Annex 1). Additional annexes provide supplementary results and further robustness checks (Annexes 3-4).

\section{Market Developments Before And During the COVID-19 Pandemic Crisis}

\section{A. Data Description}

The basis for our analysis is a comprehensive dataset of CRE prices covering 30 economies - 23 advanced economies and 7 emerging market economies_obtained from MSCI Real Estate. ${ }^{5} \mathrm{CRE}$ price data are deflated using the overall consumer price index (CPI) index and date back to 2000:Q1 for most economies. Other CRE-related variables such as net operating income (NOI) and vacancy rates are also obtained from MSCI Real Estate, while the macro-financial data are from various sources including the Bank for International Settlements, national statistical offices, and the IMF. See Table 1 and Annex 1 for summary statistics and details on data sources and transformations.

\section{B. Dynamics in Commercial Real Estate Financial Metrics over the Past Two Decades}

In the run-up to the COVID-19 pandemic crisis, the median CRE price across economies in the sample steadily increased. In Sweden and the United States, for example, real CRE prices almost doubled between 2009 and 2019 (Figure 1, panel 1). This increase occurred on the back of a prolonged period of low interest rates, which incentivized investors' search for yield and boosted demand for CRE assets. ${ }^{6}$

As of the end of 2019, the commercial real estate sector had total assets of about 20 percent of GDP, on average, across major advanced and emerging market economies, up from 17 percent a decade ago, and as high as 50 percent or more in economies such as Singapore, Sweden, and Switzerland. ${ }^{7}$ Banks are significantly exposed to the sector. For example, in the United States and some European economies, such as Estonia and Poland, direct lending related to commercial real estate constituted more than 50 percent of total bank lending to nonfinancial corporations in 2019.

Some segments of the CRE market, such as retail, however faced increasing headwinds in the prepandemic years due to a structural shift in consumer preferences away from brick-and-mortar retail towards e-commerce. This put downward pressure on revenues and led to a general decline in the capital growth of these properties (Figure 1, panel 2). Other segments such as office

\footnotetext{
${ }^{5}$ Unless stated otherwise, the core sample of economies includes Australia, Austria, Belgium, Canada, China, the Czech Republic, Denmark, France, Germany, Hong Kong SAR, Hungary, Indonesia, Ireland, Italy, Japan, Korea, Malaysia, The Netherlands, New Zealand, Norway, Poland, Portugal, Singapore, South Africa, Spain, Sweden, Switzerland, Thailand, the United Kingdom, and the United States. The exact sample composition varies across the analyses depending on the data availability of the variables used.

${ }^{6} \mathrm{CRE}$ price growth tends to be highly correlated with changes in measures of global liquidity (proxied by the total volume of international bank lending and international bond issuance). Across the sample, the country-specific correlation ranges from 0.1 to 0.4 , with a median of 0.3 .

${ }^{7}$ As noted, these values pertain to professionally managed commercial real estate because of data availability. A broader definition of the commercial real estate sector would lead to a significantly higher market size (see Nareit 2019).
} 
buildings and multifamily dwellings fared well in the pre-pandemic period, with nominal annual capital appreciation averaging about 3 percent globally.

\section{CRE Market Disruptions during the COVID-19 Pandemic Crisis}

During 2020, global real estate transaction volume fell by 39 percent, to its lowest level since 2012 (Figure 2, panel 1). This decline in part reflects the traditional features of a recession, including deteriorating occupier market conditions, disruptions to cashflow and increased risk aversion among investors and lenders due to heightened economic uncertainty. However, physical restrictions arising from measures introduced to curb the spread of COVID-19 played a significant role as well. Transaction volume fell sharply with declines mirroring the increase in Hale et al. (2021)'s COVID-19 Global Stringency Index, which is a composite measure of lockdown restrictions globally (Figure 2, panel 2). ${ }^{8}$

Among the major CRE segments, retail and hotel were the most affected, while the industrial segment fared relatively better (Figure 2, panel 3). On a same-store basis, ${ }^{9}$ the biannual net operating income (NOI) of retail assets declined by 21.4 percent, while hotel assets saw a 40 percent drop during the first half of 2020. Industrial property's net income grew 1.4 percent, which was only marginally down compared to the prior six-month period. The office sector NOI growth remained flat, despite the uncertain demand outlook for corporate office space, while residential property also recorded flat net income growth for the six months to June 2020 .

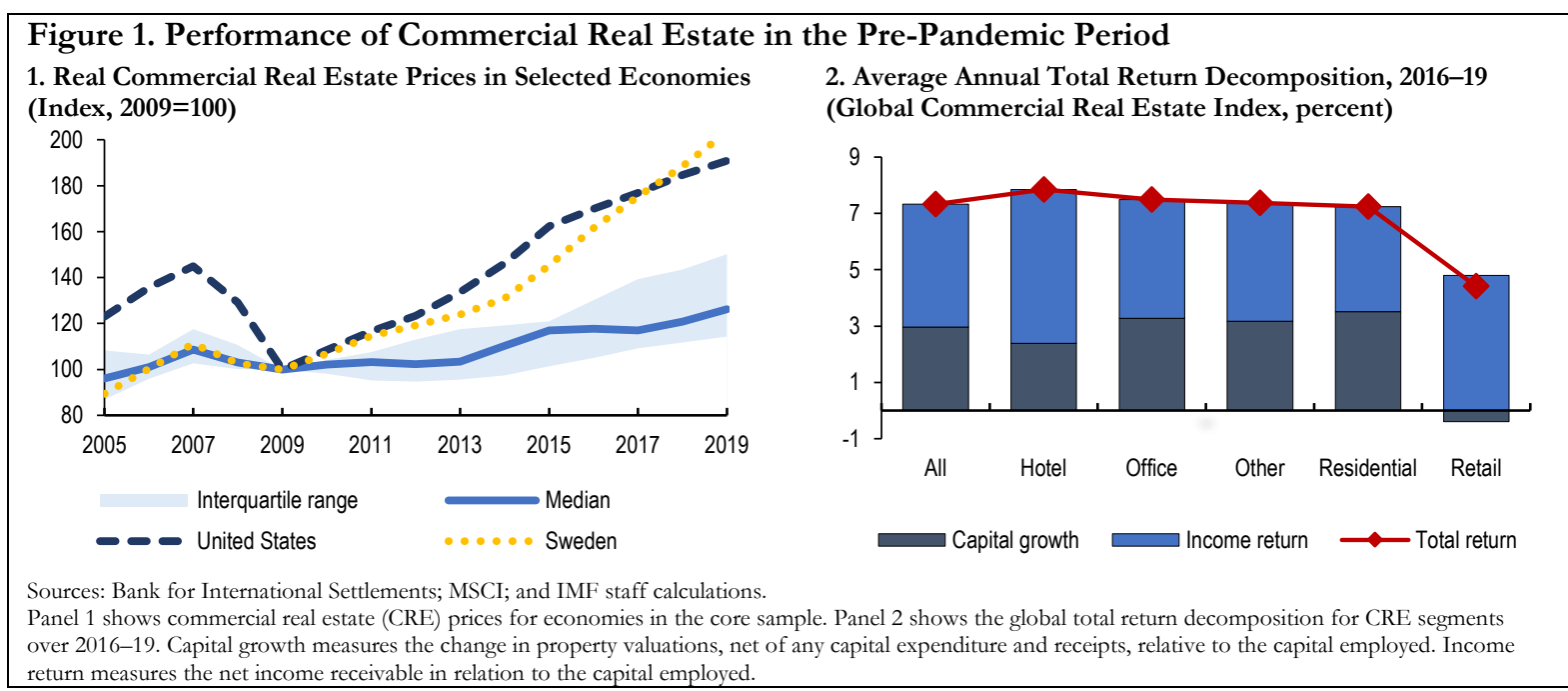

The impact of the COVID-19 pandemic on commercial real estate prices has also varied widely across and within economies. In the aggregate, declines in NOI translated into large drops in valuation in the U.S. and in Europe (Figure 2, panel 4). At the city-level, prices declined the most

\footnotetext{
${ }^{8}$ The Global Stringency Index is a measure that gauges various restrictions, including those related to social distancing, workplace openings, physical meetings, public gatherings and international travel during the COVID-19 pandemic.

${ }^{9}$ The same-store sample refers to a subset of properties of that have been held in a portfolio over a full primary measurement period - the shortest unit of time over which market or portfolio performance is being assessed.
} 
in Canada during the second quarter of 2020, with Winnipeg recording the highest quarter-overquarter decline of about $5 \frac{1}{2}$ percent. In contrast, prices in French cities generally increased during this period. Among "first-tier" cities, London recorded the largest fall ( -1.2 percent), followed by New York (-1 percent).

As lower revenues translate into reduced debt-servicing capacity and expectations of higher delinquency rates on CRE loans, strains quickly emerged in credit markets. This is evident from a surge in delinquencies on commercial mortgaged-backed securities (CMBS) - a type of fixedincome investment product that is backed by mortgages on commercial properties. While overall delinquency rates for the sector are comparable to those during the global financial crisis, delinquencies in the retail and hotel sectors reached an all-time high in the second quarter of $2020 .{ }^{10}$

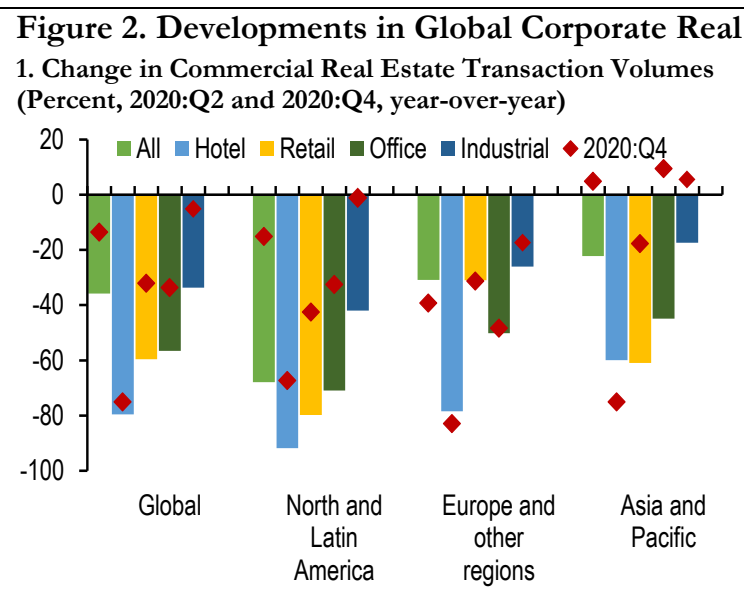

\section{tate Markets During the COVID-19 Crisis \\ 2. Commercial Real Estate Price Growth Rate (Percent versus 3-year average)}

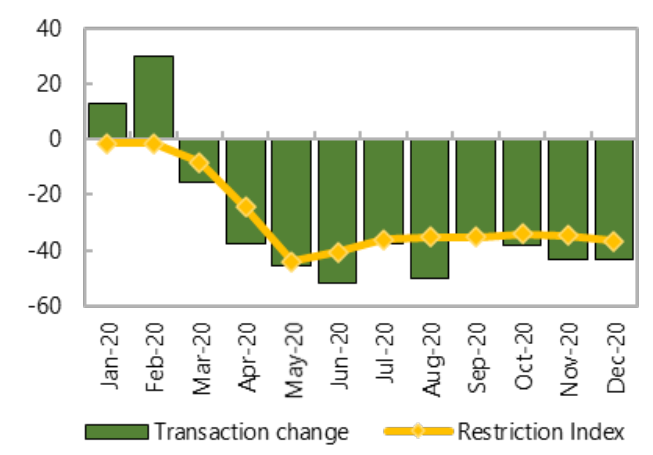

3. Global Net Operating Income Growth Rate

(Percent, six-month growth rate)

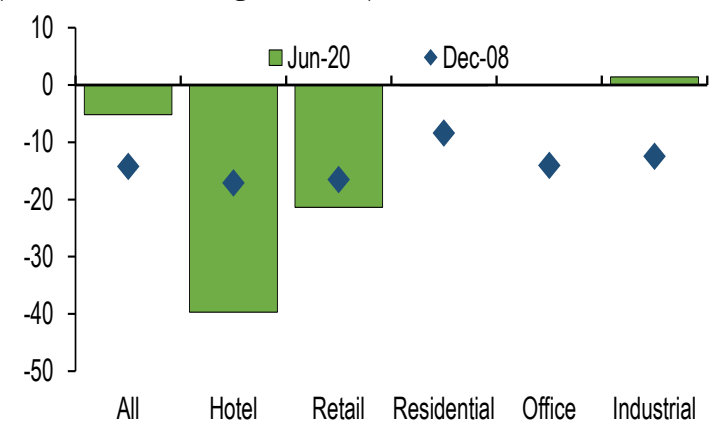

4. Commercial Real Estate Prices

(Percent, 2020:Q2 and latest, year-over -year)

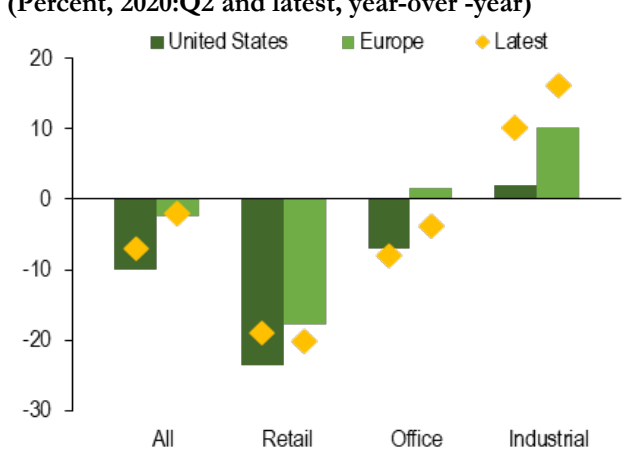

Sources: Green Street Advisors; MSCI; Oxford COVID-19 Government Response Tracker; Real Capital Analytics; and IMF staff calculations.

Note: In panel 2, the containment stringency indicator is defined as in Hale and others (2020). In panel 3, core commercial real estate segments for the overall market ("All") include hotel, industrial, office, residential, and retail. Residential refers to multifamily properties. In panel 4, latest data available are for January 2021 in Europe and February 2021 in the United States. Prices in US dollars are used to construct panels 3 and 4 .

\footnotetext{
${ }^{10}$ Similarly, special servicing rates during the COVID crisis also clocked in at new all-time highs for lodging (26.04) and retail (18.32) in September, bumping the overall reading to a post-GFC crisis high of 10.48 percent.
} 
Finally, global office vacancy rates continued to rise, most notably in the United States, where the subleasing of surplus office space kept pushing up availability, especially in tech-driven markets. For example, the vacancy rate of office space in the United States was about 9 percent at the end of 2019 but increased to 17 percent at the end of 2020 (Cushman and Wakefield, 2021). Similarly, vacancy rates increased in Australia, and other major Asia Pacific markets such as Singapore, where a weaker demand was unable to absorb new supply. In Europe, vacancy remained low in Paris and major German cities such as Berlin and Munich but increased in London.

\section{Comparison with Previous CRE Market Downturns}

The commercial real estate sector is intricately connected with macro-financial stability. Prices in this sector thus turn out to be highly procyclical: the short-term cross-correlation between changes in real commercial real estate prices and real GDP growth is strongly positive across economies (Figure 3, panel 1).

While CRE market downturns have also occurred in the past across economies, price corrections have varied considerably in magnitude and duration (Figure 3, panel 2). In the United States, for instance, before the COVID-19 pandemic, CRE prices had fallen twice since 1998-by 3 percent after the dot-com bubble burst in 2001 and by 31 percent during the global financial crisis (GFC). After these drops, however, prices started to recover in the next 2 years, reaching their pre-crisis highs within few years. By contrast, Ireland's CRE prices experienced a sharp during the global financial crisis of about 70 percent (nominal), but never fully recovered.
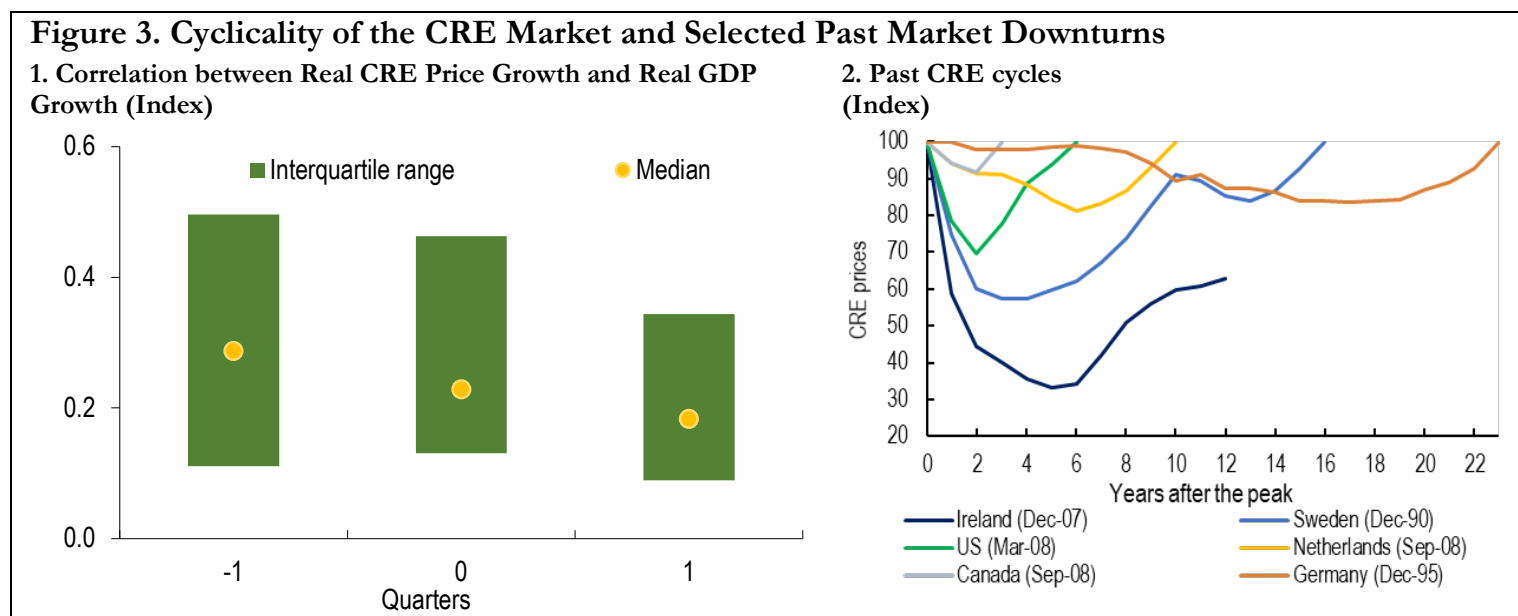

Sources: Haver Analytics; MSCI Real Estate; Refinitiv Datastream; and IMF staff calculations

Note: Panel 1 shows the median and interquartile range of the correlation between commercial real estate (CRE) prices and real GDP growth at time $t-1, t$, and $t+1$, computed country by country.

One notable feature of the post-GFC period was a lag in the recorded performance of real estate assets relative to wider equity markets. Equities lost about a third of their value in the second half of 2008 before staging a strong rebound in 2009. In contrast, the initial impact of the crisis on private real estate assets was modest but became much more severe in 2009 —even after the equity market rebound was well under way. This pattern is present in the more recent downturn as well. In principle, the lagged trend in real estate valuation can reflect several factors, including natural 
lags in the valuation process, a lack of evidence for appraisers to accurately lower or raise values when transaction volume slows, and the lengthy time for real estate cash flow to adjust to weaker economic conditions given the long-term lease structures. ${ }^{11}$

The key distinguishing factor of the COVID-19-induced downturn is its origin as a public health crisis. This cause is truly exogenous to the economic developments, by contrast with previous downturns that generally stemmed from endogenous systemic crises fueled by excess supply of CRE or excessive financial imbalances in the system. The specific nature of the COVID-19 shock is reflected in the heterogeneity of the impact on NOI across different segments, with contactintensive segments being the most affected.

Another unique feature of the COVID-19-induced downturn is that policy action was swifter, more sizable than during the GFC. This helped cushion the impact of the shock to a large extent. In addition, investors in general have a better solvency position pre-COVID than they did in the early stages of the global financial crisis. Finally, the growth of real CRE assets was also more limited in the runup to the pandemic crisis. Even in the top quartile of markets ranked by growth in stock, only 2 percent of stock was expected to be added each year compared with an average of 6 percent per year recorded ahead of previous downturns according to market agencies.

Nevertheless, given the lags in real estate valuation, it is possible that there might be further downward pressure on CRE values going forward, at least for some segments and in some economies. To this end, the next section introduces a new approach to quantify the extent to which CRE prices reflect macroeconomic fundamentals and the likelihood of a large price correction.

\section{CRE Valuation And Price Misalignment}

\section{A. A Structural Model for the Price-to-Net-Operating-Income Ratio}

To investigate the extent to which actual CRE prices reflect economic fundamentals, a formal analysis is necessary as simple rule-of-thumb measures present a mixed picture. For example, the upward trend in CRE prices before the pandemic has been accompanied by a fall in the capitalization rate - a traditional valuation metric defined as the ratio of net operating income to CRE prices - to its lowest level since the global financial crisis, which could be interpreted as a sign of CRE price overvaluation (Figure 4, panel 1). At the same time, however, long-term real government bond yields have also declined and the spread between the capitalization rate and government bond yields has remained within a narrow range, which would not support the notion of overvaluation in CRE markets (Figure 4, panel 2).

\footnotetext{
${ }^{11}$ During the GFC indeed, the distress took a notably longer time to play out as CMBS delinquencies and special servicing rates did not reach their peak of 10.34 percent and 13.36 percent until mid-2012, several years after the start of the turmoil in 2008. Multifamily and lodging were the two most troubled asset classes, with delinquency rates for those two property types peaking at 16.93 percent (20.07 percent peak for special servicing) and 19.4 percent (25.59 percent), respectively, between the second half of 2010 and first half 2011. Apart from retail, overall delinquencies for each of the major five property sectors were elevated in the double-digits until early 2013. On the same token, the eventual economic rebound and job recovery process that followed similarly took years to unfold.
} 


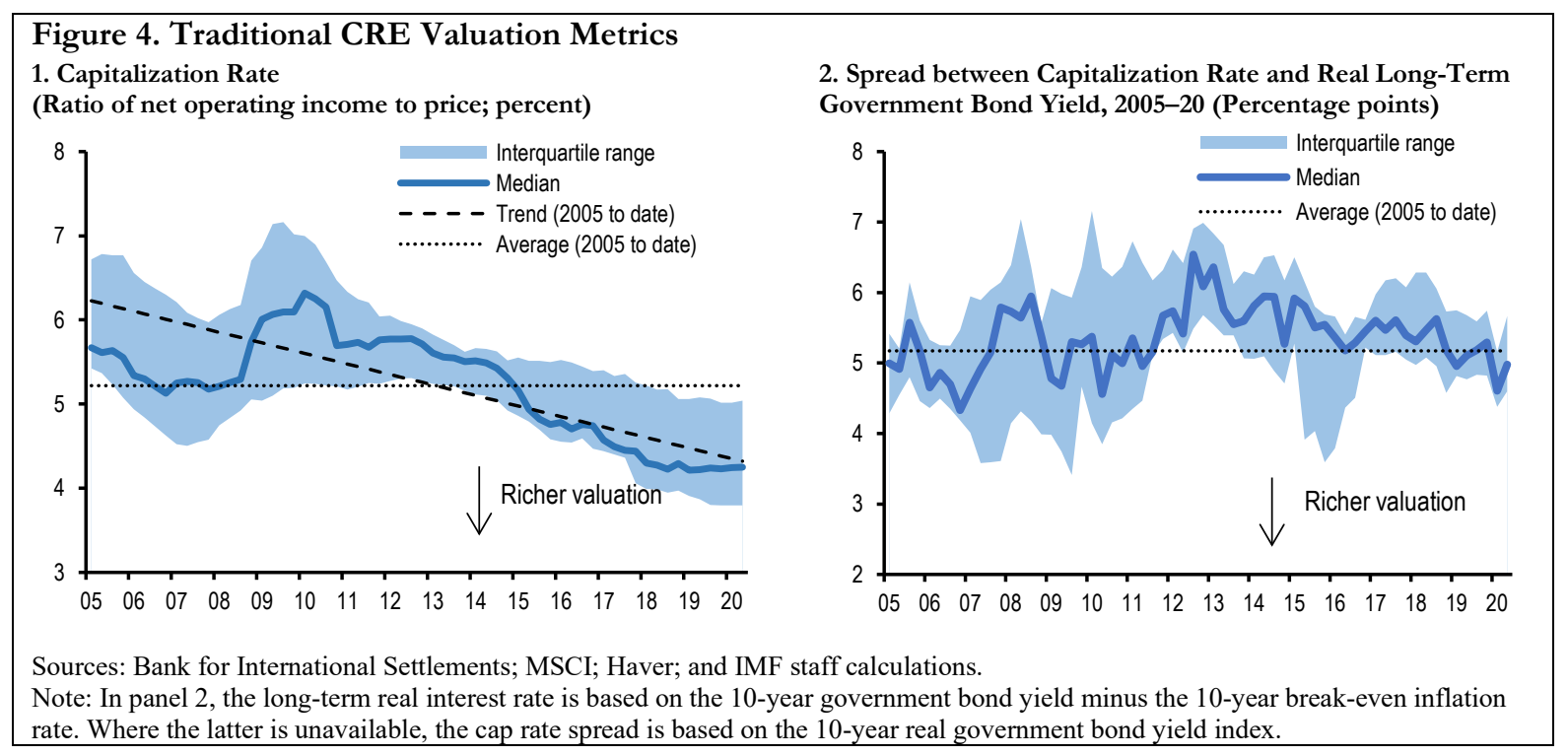

To estimate the misalignment as the difference between actual CRE prices and those implied by fundamentals, we start by defining fair CRE prices. Following Campbell and Shiller (1989), the CRE price can be expressed in terms of the current and expected growth of net operating income (NOI), and the current and expected total returns on CRE holdings:

$$
\log \left(\frac{\text { Price }_{t}}{\text { NOI }_{t}}\right)=\kappa+\rho \log \left(\frac{\text { Price }_{t+1}}{\text { NOI }_{t+1}}\right)+\Delta \log \left(N O I_{t+1}\right)-\text { Return }_{t+1}
$$

where Price $_{t}, \mathrm{NOI}_{t}$ and Returns $_{t}$ represent CRE prices deflated by CPI, net operating income deflated by CPI and total returns deflated by CPI during quarter $t$, respectively. The total returns are expressed as the sum of the 3-month short-term real interest rate and the spread of total returns over the real 3-month rate. That is, Return $_{t}=\frac{\text { Price }_{t}+\mathrm{NOI}_{t}}{\text { Price }_{t-1}}=$ Spread $_{t}+3$ MRate $_{t}-$ Inflation $_{t}$.

The variables in equation (1) are determined in a general equilibrium framework that is expressed as a structural vector autoregression (SVAR):

$$
A \boldsymbol{y}_{\boldsymbol{t}}=B_{0}+B(L) \boldsymbol{y}_{\boldsymbol{t}-\mathbf{1}}+\boldsymbol{u}_{\boldsymbol{t}}
$$

where $y_{t}$ is a vector of variables reflecting economic fundamentals; $\boldsymbol{A}$ is a matrix that captures the contemporaneous relationship between variables; and $\boldsymbol{B}(L)$ captures the lagged effect from past shocks. The vector of variables considered as economic fundamentals include NOI growth, CRE market risk premium (as measured by the spread between the capitalization rate and government bond yields), output gap, CPI-based year-on-year inflation, non-financial corporate credit-to- 
output gap, 3-month short-term interest rate, broad money-to-output, and capital flow-tooutput. ${ }^{12}$ Finally, $\boldsymbol{u}_{\boldsymbol{t}}$ represents a vector of corresponding structural shocks.

By transforming the vector of variables $y_{t}$ into companion form, the vector $\tilde{\boldsymbol{y}}_{\boldsymbol{t}}$ can be decomposed as follows:

$$
\tilde{y}_{\boldsymbol{t}}=\left(\mathbf{I}_{\mathbf{p} \times \mathbf{p}}-\mathbf{M}\right)^{-1} \mathbf{M}_{\mathbf{0}}+\sum_{k=\mathbf{0}}^{\infty} \mathbf{M}^{\mathrm{k}} \tilde{\boldsymbol{u}}_{\boldsymbol{t}-\boldsymbol{k}}
$$

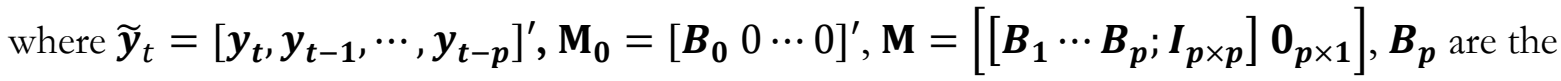
lagged coefficients with order $\boldsymbol{p}$, and $\widetilde{\boldsymbol{u}}_{\boldsymbol{t}}=\left[\boldsymbol{u}_{\boldsymbol{t}} \mathbf{0}_{\boldsymbol{p} \times \mathbf{1}}\right]^{\prime} .{ }^{13}$

Combining equations (1) and (3), we can define CRE price misalignment as the component of the detrended log Price-to-NOI ratio that cannot be explained by economic fundamentals: ${ }^{14}$

$$
\begin{aligned}
\log \left(\frac{\text { Price }_{t}}{\text { NOI I }_{t}}\right)= & \sum_{j=0}^{\infty} E_{t} \rho^{j}\left(\Delta \log \left(N O I_{t+j+1}\right)-\text { Return }_{t+j+1}\right)+m_{t} \\
& =\left(\boldsymbol{d}_{\text {NOIGrowth }}-\boldsymbol{d}_{\text {RiskPremium }}-\boldsymbol{d}_{3 \text { MRate }}\right) \rho \mathbf{M}\left(\mathbf{I}_{\mathbf{p} \times \mathbf{p}}-\rho \mathbf{M}\right)^{-1} \widetilde{\boldsymbol{y}}_{\boldsymbol{t}} \\
& +\boldsymbol{d}_{\text {Inflation }} \rho^{2} \mathbf{M}^{2}\left(\mathbf{I}_{\mathbf{p} \times \mathbf{p}}-\rho \mathbf{M}\right)^{-1} \widetilde{\boldsymbol{y}}_{\boldsymbol{t}}+m_{t}, \quad \text { (4) }
\end{aligned}
$$

where $m_{t}$ represents the misalignment and $\boldsymbol{d}_{\boldsymbol{j}}$ represents a selection vector that takes on a value of one for the $j$-th element and zero otherwise. Intuitively, the residual $m_{t}$ is the misalignment because it represents the market's over(under) valuation of the CRE price that cannot be explained by economic fundamentals.

We can further rearrange equation (4) into

$$
\begin{aligned}
\log \left(\text { Price }_{t}\right)= & \left(\boldsymbol{d}_{\text {NOIGrowth }}-\boldsymbol{d}_{\text {RiskPremium }}-\boldsymbol{d}_{3 \text { MRate }}\right) \rho \mathbf{M}\left(\mathbf{I}_{\mathbf{p} \times \mathbf{p}}-\rho \mathbf{M}\right)^{-1} \widetilde{\boldsymbol{y}}_{\boldsymbol{t}} \\
& +\boldsymbol{d}_{\text {Inflation }} \rho^{2} \mathbf{M}^{\mathbf{2}}\left(\mathbf{I}_{\mathbf{p} \times \mathbf{p}}-\rho \mathbf{M}\right)^{-1} \widetilde{\boldsymbol{y}}_{\boldsymbol{t}}+\boldsymbol{d}_{\text {NoIGrowth }} \sum_{s=0}^{t} \widetilde{\boldsymbol{y}}_{\boldsymbol{t}-\boldsymbol{s}}+m_{t},
\end{aligned}
$$

where the first two terms take the potential feedback effects among economic fundamentals into consideration. From equation (5), we calculate the contribution of different economic fundamentals to the fair value of CRE prices as the predicted difference in CRE prices with and without the observed shock to that variable.

\footnotetext{
${ }^{12}$ All variables except output gap and non-financial credit-to-output gap are demeaned. The output gap is estimated by HP- filtering GDP with a smoothing parameter of 1600. Credit-to-GDP corresponds to the Private Nonfinancial Credit to GDP ratio directly obtained from the Bank for International Settlements.

${ }^{13}$ Note that given that $\widetilde{\boldsymbol{y}}_{\boldsymbol{t}}$ is detrended, the initial value and constant term in equation (3) can be taken as negligible, which yields $\widetilde{\boldsymbol{y}}_{\boldsymbol{t}}=$ $\sum_{k=0}^{\infty} \mathbf{M}^{\mathrm{k}} \widetilde{\boldsymbol{u}}_{\boldsymbol{t}-\boldsymbol{k}}$.

${ }^{14}$ In this analysis the logarithm of Price-to-NOI ratio and NOI that are detrended with HP filter.
} 
Panel 1 in Figure 5 shows the misalignment estimated across 11 economies for which data on all variables are available over the period 2001-19. We find that most economies did not enter the pandemic crisis with large price misalignments. ${ }^{15}$ On average, the deviation of CRE prices from fair values before the pandemic is at around negative 2 percent-in contrast to the 8 percent overvaluation before the global financial crisis (Figure 5, panel 2). CRE price misalignments, however, seem to have generally increased in 2020 despite a decline in CRE prices, with the median value across economies reaching about 3.6 percent. The largest deviations of price-to-NOI ratio from fundamentals were observed in the United Kingdom and the United States exceeding 10 percent of the price level implied by the model. ${ }^{16}$

We then decompose the contribution of different economic fundamentals to CRE valuation as in equation (5). We report the results for the United States in Panel 3 of Figure 5 as an example. Predating the GFC, we find that a significant portion of the increase in valuations was driven by a rise in financial leverage and an increase in NOI. At the same time, risk premia contribute only marginally to the long-term price deviations during the run-up to the GFC. One potential reason for our findings is that weak regulatory requirements enabled banks to take on more risk, which lowered market risk premia and the extent to which credit risk was reflected in CRE pricing. This undervaluation of credit risk may have contributed to the overvaluation in CRE prices beyond the levels implied by fundamentals leading up to the GFC.

During the GFC, risk premia and NOI were negatively affected by demand and supply shocks to the real economy. Nevertheless, CRE valuations fell by more than their implied decline based on economic fundamentals, offsetting the overvaluation leading up to the GFC. Prices recovered since 2010 to an extent that can be rationalized by the expansion of unconventional monetary policy, which limited overvaluation in CRE prices post-GFC.

During the COVID-19 pandemic crisis, there was an increase in overvaluation because fundamentals deteriorated by more than CRE prices. The decline in aggregate demand and NOI, was not fully offset by the easing of monetary policy, which left CRE prices overvalued despite their decline. ${ }^{17}$

In the next section, we take a closer look at the shocks to fundamentals from the COVID-19 pandemic crisis. While some factors are conjunctural, related to the recession and the pandemic, others may reflect deeper underlying structural changes in the CRE market and the economy at large.

\footnotetext{
${ }^{15}$ The fair value model estimated here to assess the extent of potential misalignment in CRE prices from their long-run equilibrium level draws on Campbell and Shiller (1989). This approach models price as the present value of future cash flows (proxied by the expected net operating income) discounted by the expected return of holding CRE assets. The model considers the impact of economic fundamentals such as the output gap, inflation, credit-to-output ratio, short-term interest rate, broad money-to-output ratio, and capital flow-to-output ratio.

${ }^{16}$ Lack of data availability for some variables precluded reliable estimation of fair values for other CRE segments such as the hotel and industrial segments.

${ }^{17}$ The magnitude of CRE price misalignments in late 2020 varied across market segments. In general, the extent of misalignment is smaller in the office sector compared to retail, though in some economies, large overvaluations have emerged in both segments.
} 


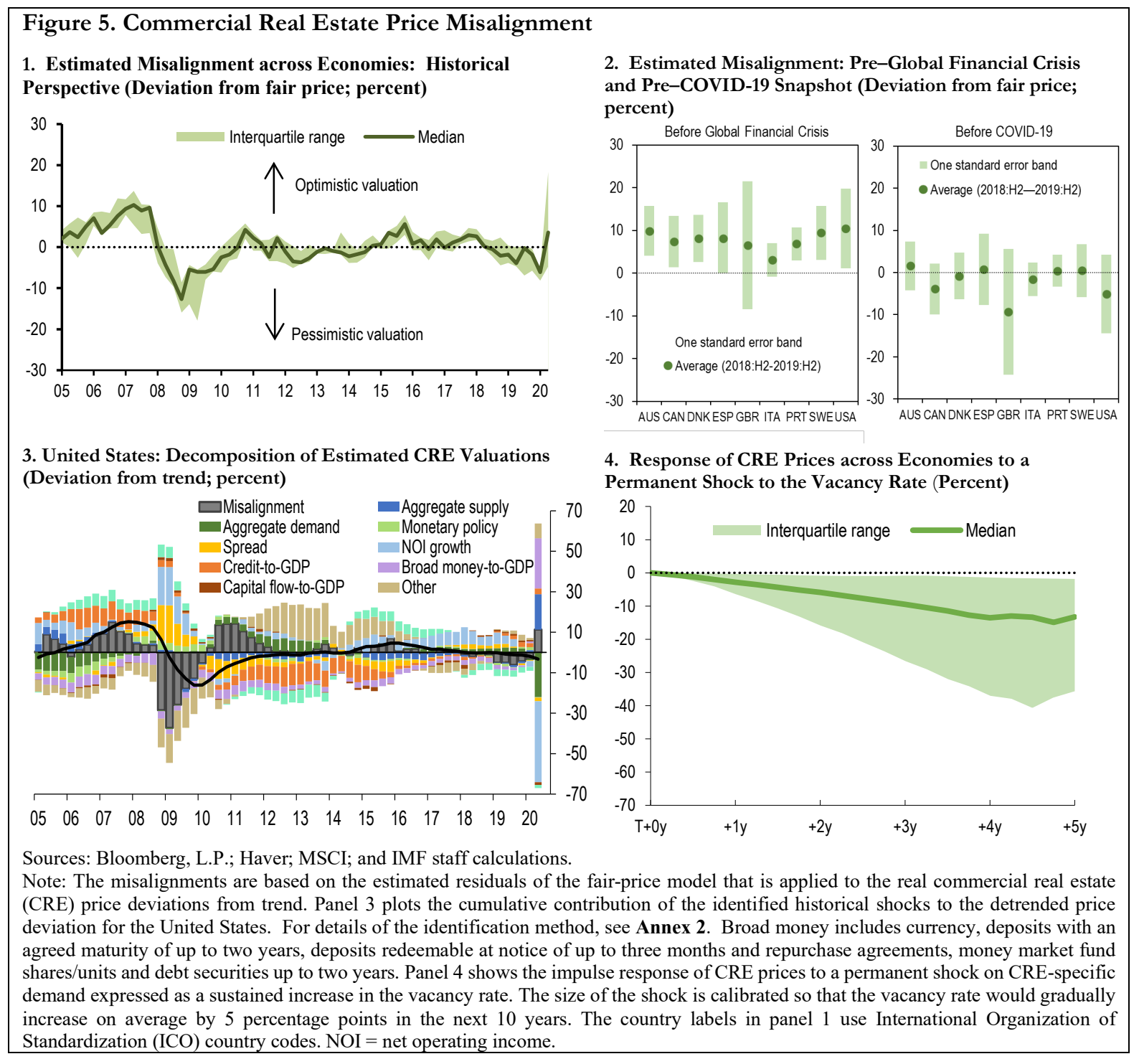

\section{B. The Implications of Structural Shifts in Demand for CRE Valuations}

While the preceding estimates of misalignment are derived from a rigorous empirical approach that considers the fundamental economic determinants of CRE prices, these factors do not take into account potential structural changes in CRE demand going forward, such as the further shift toward e-commerce and teleworking induced by the COVID-19 pandemic. Given the unprecedented nature of the pandemic, accurately forecasting the magnitude of these shifts in consumer preferences and corporate policies and their impact on CRE valuations is an extremely challenging task. Acknowledging such difficulties, we proceed to examine the effect of structural demand shifts in CRE markets on CRE fair prices through a scenario analysis. 
Specifically, CRE fair prices are estimated assuming that the demand for CRE declines continuously for the next five years, which is proxied by a persistent increase in vacancy rates. ${ }^{18}$ To this end, we first extend the fair-value model described in the previous section to include vacancy rates. The scenario analysis is then performed by adding a permanent shock to vacancy rates, which is equivalent to including a CRE-specific demand shock in the structural shock vector $\boldsymbol{u}_{\boldsymbol{t}}$ in Equation (3). Accordingly, the impulse response (Imp) can be defined as the deviation of the simulated path of the prices forecasted under the shock to $j\left(u_{\text {vacancy,t }}=1\right)$ from the one forecasted without shocks $\left(u_{\text {vacancy,t }}=0\right)$. The impulse response at horizon $T$ with the $j$-th shock is given by the following expression:

$$
\begin{gathered}
\operatorname{Imp}\left(\text { Price }_{T}\right)=E\left[\text { Price }_{T} \mid \tilde{u}_{\text {vacancy }, t}=1 \sigma \text { for all } t \leq T\right] \\
-E\left[\text { Price }_{T} \mid \tilde{u}_{\text {vacancy }, t}=0 \text { for all } t \leq T\right] .
\end{gathered}
$$

Using the companion form $\widetilde{\boldsymbol{y}}_{\boldsymbol{t}}=\mathbf{M}_{\mathbf{0}}+\mathbf{M} \widetilde{\boldsymbol{y}}_{\boldsymbol{t}-\mathbf{1}}+\widetilde{\boldsymbol{u}}_{\boldsymbol{t}}$ and equation (4), price-to-NOI and NOI can hence be simulated by forward iteration with respect to time. ${ }^{19}$ Since the model is linear, any given size of the shock simulation can be performed by rescaling the impulse response. In the simulation, we assume a 5 percent sustained increase in vacancy rates. Intuitively, if commercial spaces remain unoccupied due to a change of preferences, CRE cash flows and prices would decline. ${ }^{20}$

Panel 4 in Figure 5 shows the median and interquartile range of CRE prices in response to a permanent shock on CRE-specific demand as in equation (6). ${ }^{21}$ The results from the simulation suggest that fair values could drop sharply if demand for CRE declines permanently. While the size of the impact varies across economies, the median drop in fair values following a permanent increase in the vacancy rate by 5 percentage points would be about 15 percent after five years. ${ }^{22}$

Further, there is a considerable degree of uncertainty surrounding CRE valuations both in the near and medium terms. This uncertainty could lead to continued price misalignments in the postCOVID environment, especially as financial conditions continue to ease in major economies, but with sharply divergent growth trajectories in some emerging markets. In the discussion that follows, we investigate the potential implications of such price misalignments on the future downside risks to CRE prices.

\footnotetext{
${ }^{18}$ Since shocks to the vacancy rates are exogenous in the model, the shift in demand due to the structural change in preferences is assumed to be unexpected.

${ }^{19}$ Annex 2 reports the impulse response functions for CRE prices and risk premia for the United States as an example.

${ }^{20}$ If actual prices do not follow suit, perhaps because of valuation uncertainty, prices may become overvalued, which could increase the risk of a sharp price correction down the road.

${ }^{21}$ The estimation results are based on a more restricted sample of economies with available vacancy data. The restricted sample includes: Australia, Canada, Denmark, Spain, Italy, Portugal, Sweden, the United Kingdom, and the United States.

${ }^{22}$ A 5-percentage point decline in the vacancy rate is equivalent to that experienced by the United States during the global financial crisis. The scenario further abstracts from a potential repurposing of properties in individual CRE sectors to others.
} 


\section{The Effect of CRE Price Misalignment on Downside Risks to CRE Price Growth}

Price misalignment is an important indicator to assess the level of vulnerability in the CRE sector. Intuitively, the larger is the divergence between market prices and fundamentals, the higher is the likelihood of a price correction. In this section we explore this hypothesis by constructing a commercial-real-estate-prices-at-risk $(\mathrm{CaR})$ measure to gauge downside risks to CRE prices over different horizons and to identify the impact of CRE prices misalignment on potential future price corrections.

By focusing on different horizons, the estimated effect of misalignment in the CaR model allows us to establish a "term structure" of CRE price risks, reflecting short-term and medium-term responses to a given factor. The estimation methodology follows previous studies focused on house prices (e.g., Deghi et al, 2020) and adopts a two-step procedure for panel quantile regressions based on Canay (2011). ${ }^{23}$ We provide a brief description of the general setup below.

Define $\Delta_{h} Y_{i, t+h}$ as the average log change in commercial real estate prices, $h$ periods ahead, for economy $i{ }^{24}$ Let $X_{i, t}$ be a vector consisting of explanatory variables, and country fixed effects. In this setting, quantile local projections can be estimated based on:

$$
\begin{aligned}
\hat{\beta}_{\tau, h} \equiv \underset{\widehat{\beta}(\tau, h)}{\operatorname{argmin}} \sum_{t=1}^{T}\left(\tau \mathbb{1}\left(\Delta_{\mathrm{h}} y_{i, t+h} \geq X_{i, t} \beta_{h, \tau}\right)\left|\Delta_{h} y_{i, t+h}-X_{i, t} \beta_{h, \tau}\right|\right. \\
\left.+(1-\tau) \mathbb{1}\left(\Delta_{h} y_{i, t+h}<X_{i, t} \beta_{h, \tau}\right)\left|\Delta_{h} y_{i, t+h}-X_{i, t} \beta_{h, \tau}\right|\right), \quad(7)
\end{aligned}
$$

where $\mathbb{1}(\boldsymbol{\square})$ denotes the indicator function and $\tau \in(0,1)$ corresponds to the $\tau_{\text {th }}$ quantile. The quantile of $\Delta_{h} Y_{i, t+h}$ conditional on $X_{i, t}$ is then given by:

$$
Q_{\tau}\left(\Delta_{h} y_{i, t+h} \mid X_{i, t}\right)=X_{i, t} \hat{\beta}_{\tau, h} \equiv \mathrm{CaR}_{\tau, \mathrm{i}, \mathrm{h}}
$$

The coefficient $\hat{\beta}_{\tau, h}$ measures the effect of $X_{i, t}$ on the $\tau$ quantile of the conditional distribution of $\Delta_{h} y_{i, t+h}$. Hence, these coefficients vary depending on the quantile selected. The approach to calculate quantile local projections resembles the way in which local projections based on means are computed with two exceptions. First, the quantile regression minimizes the sum of absolute errors rather than the sum of squared errors. Second, it puts differential weights on the errors depending on whether an error term is above or below the quantile. Since the model is nonlinear, the marginal effect of control variables has to be evaluated accordingly. For a given CRE price

${ }^{23}$ Quantile regression is an extension of linear regression to focus on other quantiles of the distribution than the conditional mean and can therefore be used to explore tail risks.

${ }^{24}$ Specifically, $\Delta_{h} Y_{i, t+h}$ is the expected average growth of real commercial real estate prices, $\Delta_{h} P_{i, t+h} \equiv\left(\log P_{i, t+h}-\log P_{i, t}\right) / h$. 
determinant, $X_{i, t}$, and a given quantile of the future CRE price distribution, $\tau$, the sequence of coefficients $\hat{\beta}_{\tau, h}$ estimated at different horizons, $h$, shows how an increase in $X_{t}$ changes the quantile of future CRE price growth at those forecasting horizons. Future projections of CRE price growth at a given quantile $\tau$ capture downside risks to future CRE prices growth and are defined as commercial-real-estate-prices-at-risk.

The set of controls $\left(X_{i, t}\right)$ include past growth in CRE prices (which captures momentum effects), CRE price misalignment, and selected fundamental factors described in the previous section, such as GDP growth, credit-to-GDP growth, capital flow-to-GDP and an index to control for financial conditions and monetary aggregates developments. ${ }^{25}$ Lagged CRE prices are especially relevant because they may reflect the persistence in CRE prices as well as the role of persistent omitted variables, such as supply restrictions or the stock of CRE properties.

Figure 6 displays the coefficients of CRE price misalignment estimated using the panel quantile local projections as in equation (7). ${ }^{26}$ In the analysis, we focus on the 5 th percentile of the conditional distribution of CRE price growth to investigate the effect of current CRE price misalignment on downside risks to prices in the sector. Because of limited data availability in the full sample, we calculate CRE misalignment as the (sign inverted) deviation of capitalization rates from the historical trend instead of using the measure discussed in subsections III A-B above. By estimating the model on a smaller sample of countries using the misalignment measure described in the previous section, results remain however broadly consistent.

Our findings show that an increase in CRE price misalignment is associated with greater downside risks in CRE prices growth over time, especially in advanced economies. A one-standard deviation higher price misalignment (corresponding to 10 basis points) is associated with a (cumulative) 2.5 percentage point increase in downside risks to CRE prices in advanced economies and a 1.1 percentage point increase in emerging market economies over four quarters. The association between current price misalignment and future price correction is long-lasting and reaches 10 percentage points in advanced economies over twelve quarters (cumulatively).

When looking at the predicted CaR value across our core sample of 30 economies, we find that downside risks to future CRE price growth fluctuate substantially over time. For instance, 1-year projection of $\mathrm{CaR}$ have deteriorated during the GFC recording an average quarterly CRE price decline of 12 percent on an annualized basis at the end of 2007 (Figure 6, panel 2). Similarly, in the most recent period, the median CaR appears to have synchronized across major economies,

\footnotetext{
${ }^{25}$ The number of regressors play a relevant role in quantile regressions. A more parsimonious specification not only limits the computational burden of parameters estimation, but also the likelihood of quantile crossing which could lead to invalid results. See e.g. Chernozhukov (2002)

${ }^{26}$ Coefficients are standardized to allow for a comparison of the relative magnitude of the effects of different explanatory variables.
} 
showing a common decline due to the COVID-19 pandemic. Importantly, among the key factors driving these fluctuations, price misalignment plays a key role. As shown in Table 2, the standardized coefficients of the CRE price misalignment variable are the largest across the key factors in the panel quantile estimation after the fourth quarter in the forecasting horizon. These findings lend further support for the relevance CRE price misalignment for financial stability.

For robustness, we re-estimate our specification controlling for time-varying effects (Annex Table A3.1) and using different percentiles (Annex Table A3.2). We also use an alternative panel quantile estimation methodology based on Machado and Silva (2019) to obtain our estimates (Annex Table A3.3). Overall, the results are robust and consistent with those of the baseline estimation.

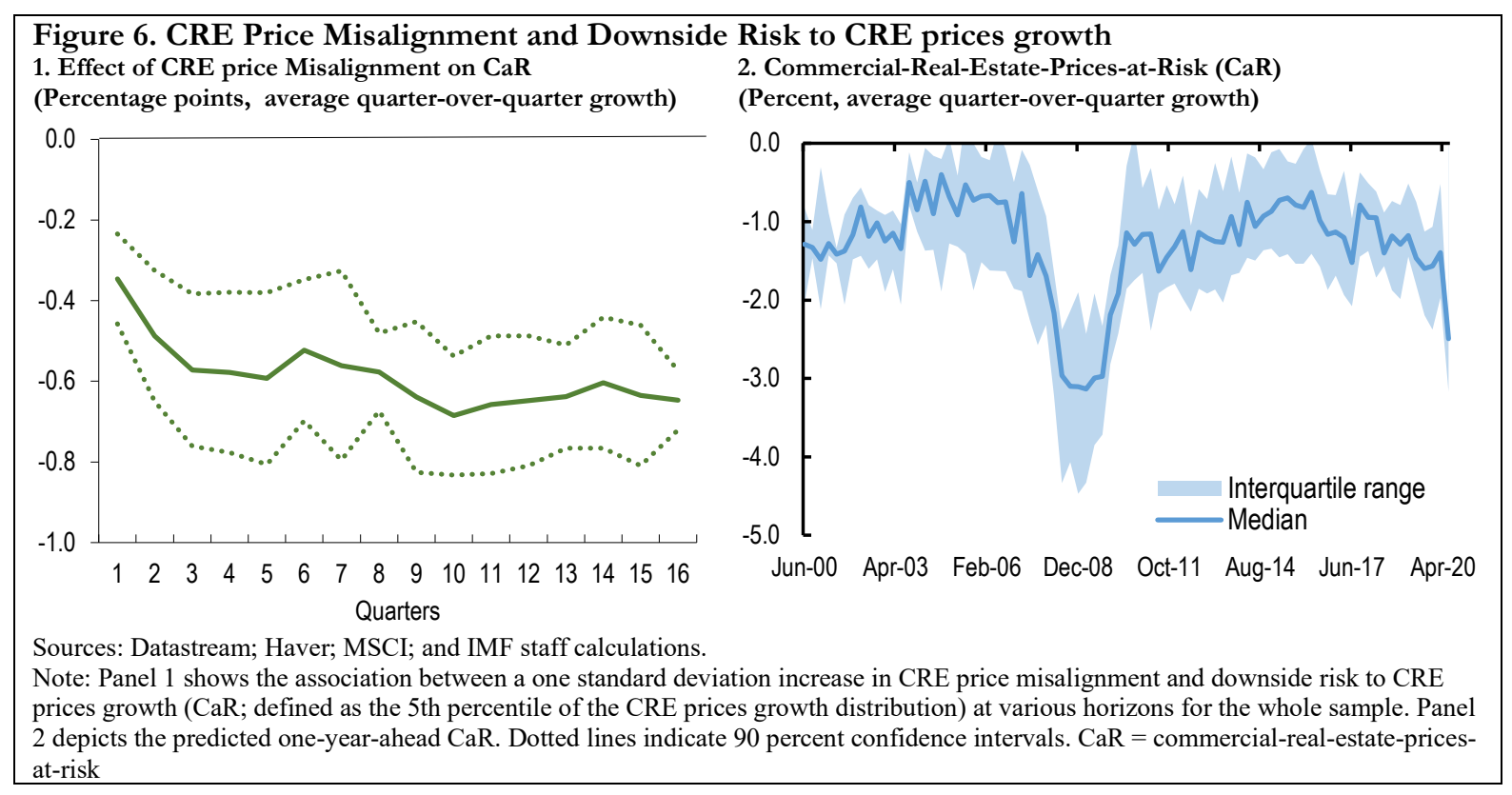

\section{CRE Price Misalignment And MaCrofinancial Stability}

Conceptually, there are different channels through which a decline in commercial real estate prices can affect financial stability. One source of vulnerability is the misalignment in prices from economic fundamentals, where a higher misalignment likely implies a sharper fall in prices in the future. The price misalignment can also interact with other financial vulnerabilities that amplify the magnitude of price correction.

Another source of vulnerability stems from the financial (or balance sheet) strength of borrowers and lenders in the commercial real estate market such as the extent of their leverage, which can create a feedback loop between credit growth and asset prices. A downturn in CRE markets can worsen the credit quality of borrowers by affecting the strength of their income streams and balance sheets. In the event of a borrower default, banks incur losses, and their capital positions are weakened, which may in turn lead them to reduce the credit supply to the economy and amplify 
the initial adverse shock in CRE prices. This feedback loop is amplified when the initial level of bank credit, i.e., leverage, in the economy is higher.

At the same time, foreign investors and cross-border flows to CRE markets can increase risks to financial stability by amplifying boom-bust cycles. Past studies found a high correlation between capital inflows and price booms in real estate markets (Aizenman and Jinjarak, 2009) and documented the presence of global financial cycles that direct international capital flows (Fratzscher 2012). Domestic CRE markets may become more synchronized with global CRE cycles when, for example, international investors chase yields in the same prime locations across countries. Furthermore, foreign investors, especially nonbanks, may remove their funds from CRE markets more quickly than domestic investors if returns become more attractive abroad or if market uncertainty rises. Thus, a sudden stop or reversal of foreign investors' demand could increase the probability of a sharp decline in CRE prices, which could in turn be transmitted to domestic financial markets and the real economy.

Against this background, we examine how CRE price misalignment affects financial stability and to what extent the impact is amplified by other financial vulnerabilities. To identify the potential impact of shocks to CRE prices on macro-financial stability, we examine the effect of CRE price misalignment, which is an indicator for the risk of future price corrections, on the downside risk to GDP growth, which is defined as the range of most severe GDP growth outcomes ${ }^{27}$

The potential amplification of CRE price misalignment on the downside risks to real GDP growth is assessed using the local projections approach in a quantile regression setting similar to that described in Section III.C. The model specification is as follows:

$$
\Delta_{h} Y_{i, t, \tau}=\alpha_{i, \tau}^{h}+\beta_{\tau}^{h} \mathrm{CRE}_{\text {Misalignment }} \mathrm{i}_{\mathrm{i}-1}+\theta_{\tau}^{h} \text { Controls }_{i, t-1}+\epsilon_{i, t, \tau}^{h}
$$

where $\Delta_{h} Y_{i, t, \tau}$ denotes the (average) percentage change in real GDP growth in country $i$ from the base quarter $t$ to $t+h(h=1,2, \ldots, 16)$, at quantile $\tau$ ( $5^{\text {th }}$ percentile). Because of limited data availability in the full sample, we calculate CRE price misalignment as the (sign inverted) deviation of capitalization rates from the historical trend. As in Section III.C, we also estimate the model on a smaller sample of countries using the misalignment measure described in section III.A and find broadly consistent results. Controls include lagged GDP growth, the financial conditions index (purged of CRE price variations) and credit-to-GDP gap. Since developments in the residential real estate market and CRE are strongly interlinked, all the regressions control also for house prices growth.

\footnotetext{
${ }^{27}$ GDP downside risks are defined here as the 5 th percentile of the cross-country distribution of future (average) real GDP growth. To broaden the sample for this exercise and include both advanced and emerging market economies, the misalignment measure considered here is the deviation of the capitalization rate from its historical trend (instead of the misalignments derived from the fair value model in the previous section, which can be computed for very few countries because of data limitations).
} 

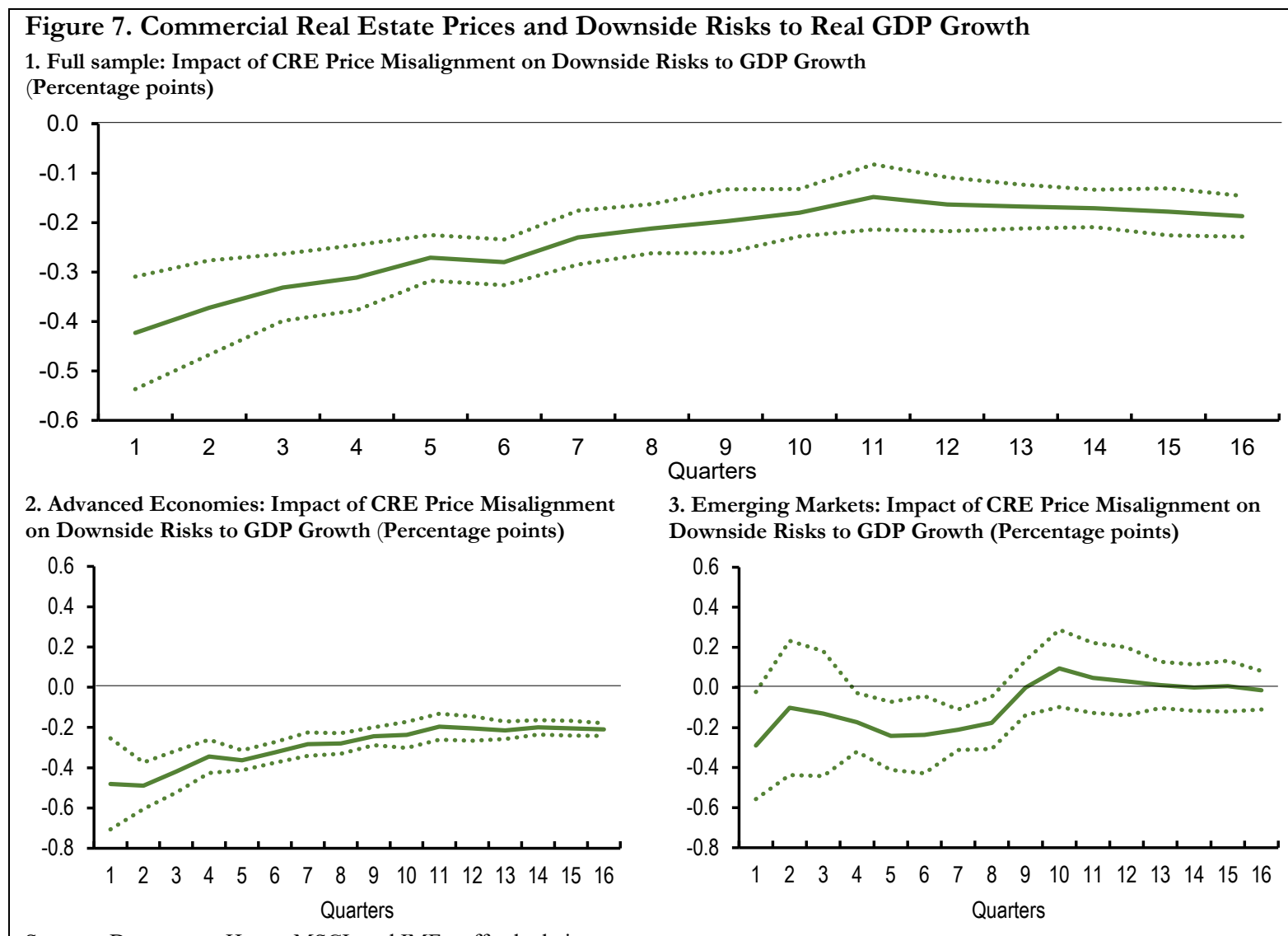

3. Emerging Markets: Impact of CRE Price Misalignment on Downside Risks to GDP Growth (Percentage points)

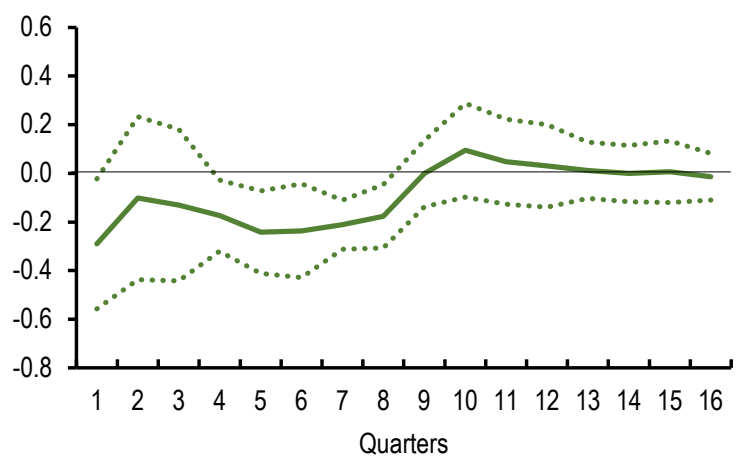

Sources: Datastream; Haver; MSCI; and IMF staff calculations.

Note: Panels 1-3 show the association between a one standard deviation increase in CRE price misalignment (corresponding to a negative deviation of the capitalization rate from its long-term trend by 10 basis points in advanced economies and 0.08 percent in emerging markets) and downside risk to GDP growth (defined as the 5th percentile of the GDP growth distribution) at various horizons for the whole sample as well as across country groups. Dotted lines indicate 90 percent confidence intervals.

Table 3 reports the estimation results of equation (9) for our core sample of countries. Our main interest is in the coefficient $\beta_{\tau}^{h}$, which indicates the impact of a one standard deviation increase in CRE price misalignment on the $5^{\text {th }}$ percentile of the future GDP growth distribution. The estimated coefficient $\hat{\beta}_{\tau}^{h}$ is plotted separately in Figure 7 panel 1 over the projection horizon.

Our estimates show that a one-standard-deviation increase in the misalignment measure corresponding to a negative deviation of the capitalization rate from its long-term trend by 10 basis points-raise downside risks to GDP growth by 1.4 percentage points in the short term (cumulatively over 4 quarters) and 2.5 percentage points in the medium term (cumulatively over 12 quarters). The coefficients $\hat{\beta}_{\tau}^{h}$ are negative and statistically significant across the entire forecasting horizon. Our results are also robust to the inclusion of credit-to-GDP gap measures, which dispels the concern of confounding effects due to the correlation between GDP and financial leverage.

Since the structure of the financial system and CRE markets may differ across advanced and emerging market economies, we re-estimate equation (9) for the two groups of countries separately. We report the full regression results in Table 4 and plot the estimated coefficients 
$\hat{\beta}_{\tau}^{h}$ over the projection horizon in panels 2 of Figure 7 for advanced economies and in panel 3 for emerging market economies. In advanced economies, we find that a one-standard-deviation increase in CRE price misalignment is associated with an increase in downside risk to GDP growth of 0.5 percentage points in the short term and 0.25 percentage points in the medium term. For emerging market economies, the impact is about 0.2 percentage points in the short term.

These findings confirm that the downside risk to GDP growth increases when CRE price misalignments are larger. Importantly, the effect of CRE price misalignment on GDP growth is significant in both advanced and emerging market economies, though the impact is smaller and statistically weaker for the latter. A possible explanation for the lower estimated impact for emerging market economies could be related to the smaller size of their CRE markets and the lower credit-to-GDP gap relative to advanced economies.

We then examine the extent to which the impact of CRE price misalignment on GDP downside risk is amplified by other financial vulnerabilities. The specification in equation (9) is extended to evaluate the interaction effects between the level of price misalignment and other macrofinancial vulnerabilities. In light of our earlier discussion on balance sheet strength and volatile foreign investment as sources of vulnerability in the CRE market, we interact price misalignment with the credit-to-GDP gap and cross-border CRE-capital-flows-to-GDP gap. ${ }^{28}$ The extended specification takes the following form:

$$
\begin{aligned}
\Delta_{h} Y_{i, t, \tau} & =\alpha_{i, \tau}^{h}+\beta_{\tau}^{h} \text { CRE Misalignment }_{\mathrm{t}-1}+\lambda_{\tau}^{h} \text { CRE Misalignment }_{\mathrm{i}, \mathrm{t}-1} * \text { Vulnerability }_{i, t-1} \\
& +\theta_{\tau}^{h} \text { Controls }_{i, t-1}+\epsilon_{i, t, \tau}^{h}
\end{aligned}
$$

where Vulnerability $y_{i, t-1}$ is either the credit-to-GDP gap or the cross-border CRE-capital-flowsto-GDP gap; Controls $s_{i, t-1}$ include the vulnerability indicator without interaction. All the covariates are standardized before estimation.

Table 5 reports the results from the estimation of equation (10), where the CRE price misalignment is interacted with the credit-to-GDP gap that indicates the level of financial leverage. Panel 1 of Figure 8 shows the estimate of the coefficient of CRE price misalignment, $\hat{\beta}_{\tau}^{h}$ (in green), and its sum with the coefficient of the interaction term with financial leverage, $\hat{\beta}_{\tau}^{h}+\hat{\lambda}_{\tau}^{h}$ (in blue). Since all covariates are standardized before estimation, $\hat{\beta}_{\tau}^{h}$ and $\hat{\beta}_{\tau}^{h}+\hat{\lambda}_{\tau}^{h}$ amount to the effect of CRE price misalignment on $\Delta_{h} Y_{i, t, \tau}$ in two scenarios with different levels of leverage. Specifically, the estimate $\hat{\beta}_{\tau}^{h}$ corresponds to the impact of CRE price misalignment when the level of credit-to-GDP gap is at its historical average ("Average Leverage"), while $\hat{\beta}_{\tau}^{h}+\hat{\lambda}_{\tau}^{h}$ equates to the impact of CRE price misalignment when the Credit-to-GDP gap is one standard deviation higher than its historical average ("Higher Leverage").

We find that economies with a higher credit-to-GDP gap are more likely to experience a severe economic downturn for the entire forecasting horizon. The amplification effect of leverage on

\footnotetext{
${ }^{28}$ Investment flows refers here to property transactions in primary and secondary markets where the location of the property is in a different country than the head quarter of the of the acquirer.
} 
downside risks to GDP growth though CRE price misalignments is both econometrically and economically significant. An economy with a higher level of leverage would incur a 50-basis-points larger GDP decline over four quarters (cumulatively) for the same level of CRE price misalignment at time $t$ should large downside risks materialize.

We obtain the amplification effect of CRE cross-border investments using a similar approach. Table 6 reports the results from estimating equation (10), where CRE price misalignment is interacted with the cross-border CRE-capital-flows-to-GDP gap used to capture the intensity of cross-border investments in the sector. ${ }^{29}$ Panel 2 of Figure 8 shows the estimate of the coefficient of CRE price misalignment, $\hat{\beta}_{\tau}^{h}$ (in green), and its sum with the coefficient of the interaction term with the cross-border investments' indicator, $\hat{\beta}_{\tau}^{h}+\hat{\lambda}_{\tau}^{h}$ (in red). The estimate $\hat{\beta}_{\tau}^{h}$ corresponds to the impact of CRE price misalignment when the level of cross-border CRE-capital-flows-to-GDP gap is at its historical average ("Average Cross-Border Investments"), while $\hat{\beta}_{\tau}^{h}+\hat{\lambda}_{\tau}^{h}$ equates to the impact of CRE price misalignment when the cross-border CRE-capital-flows-to-GDP gap is one standard deviation higher than its historical average ("Higher Cross-Border Investments").

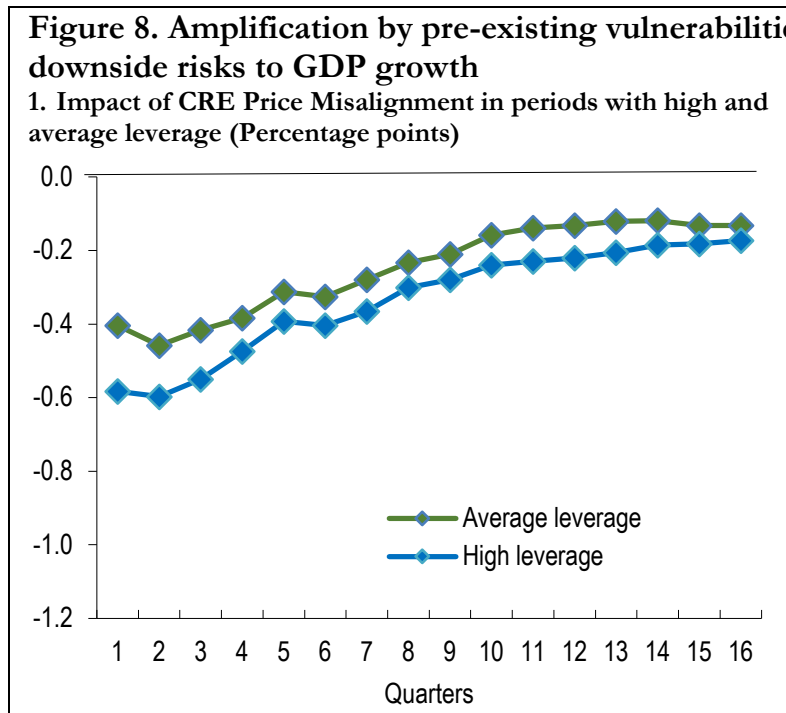

Sources: Haver; MSCI; and IMF staff calculations.

Note: Panels 1 shows the effect of CRE price misalignment separately for periods of average and high level of leverage. High level of leverage corresponds to periods where credit-to-GDP gap is one standard deviation higher than its historical average. Similarly, panels 2 shows the effect of CRE price misalignment separately for periods of average and high level of cross-border CRE capital flows-to-GDP gap. Full markers indicate statistical significance at 10 percent level or lower. CRE $=$ commercial real estate

Our results suggest that economies with higher CRE cross-border investments also have a larger effect of CRE price misalignments on the downside risk to GDP growth. Although the difference between "Average" and "Higher" cross-border investment trajectories is not significant in the short-term, it becomes statistically and economically significant after six quarters. Eight quarters ahead, for example, the per quarter price decline due to one-standard deviation increase in CRE prices misalignment increases from 0.3 to 0.4 percentage points in economies more reliant on CRE cross-border flows.

\footnotetext{
${ }^{29}$ Cross-border investment-to-GDP gap is calculated using a recursive cubic spline detrending procedure.
} 
Taken together the findings confirm that price misalignment can interact with other financial vulnerabilities, which amplifies its effect on the magnitude of economic downturns. A possible interpretation is that periods of rapid credit growth are typically accompanied by an easing of bank lending standards, and that banks' increased tolerance for risk results in lending to less creditworthy businesses leads to higher credit losses in a downturn, especially if accompanied by a large asset price correction. ${ }^{30}$

Further, we test the robustness of the results by controlling for time-varying effects (Annex Table A3.4) and by comparing the coefficients of CRE price misalignment in our baseline model against the choice of a specific percentile (Annex Table A3.5). Annex Table A3.6 reports the results using the alternative panel quantile estimation methodology described in Machado and Silva (2019). Overall, the results are robust and consistent with the baseline specification.

Finally, it is possible that the effect of misalignment on economic tail risk varies depending on the sign of misalignment. Intuitively, periods with a positive misalignment, corresponding to periods of overvaluation, should matter more for financial fragility. Hence, we further include in equation (9) an interaction term between CRE prices misalignment and an indicator variable equal to 1 when the misalignment is positive. As expected, the coefficient of the interaction term is negative and significant, while the coefficient of the single term is no longer significant. Annex Table A3.7 reports the results.

\section{Macroprudential Policy Effects on Commercial Real Estate Prices}

Given the adverse effects of CRE price misalignments on macro-financial stability documented in the previous section, an important question is whether macroprudential policies can play a role in preventing a buildup of vulnerabilities in the CRE market. While CRE price levels are not a policy objective per se, macroprudential policies could in principle mitigate the risk of large CRE price corrections and alleviate the strains from CRE price adjustments should a correction occur.

To examine the effectiveness of macroprudential policies in the context of CRE markets, we focus on targeted ("CRE-specific") policy measures that apply specifically to the CRE sector. These include borrower-based policies that limit borrowers' access to bank credit, such as CRE-specific loan-to-value (LTV) and debt service-to-income (DSTI) ratios, and capital-based policies that enhance banks' resilience, such as higher risk weights and sectoral capital buffers for CRE exposures. Information on macroprudential policies is obtained from the IMF's integrated macroprudential policy (iMaPP) database (Alam and others, 2019) as well as BIS and ESRB's policy databases. The full list of CRE-specific measures implemented across the countries in the

\footnotetext{
${ }^{30}$ The large amplification effect of CRE cross-border investments could also be linked to institutional investors like pension funds and insurance companies, whose share in cross-border investment flows has increased significantly since 2010 and who tend to be more prone to flights to safety when facing a large global shock. 30 Indeed, the greater the share of cross-border investment before the COVID-19 pandemic, the larger was the decline in total CRE investments in the first three quarters of 2020.
} 
core sample is reported in Annex Table 4.1. In some instances, these measures could also include specific limits to banks' CRE exposure concentration and supervisory guidance on CRE lending. ${ }^{31}$ CRE-specific measures are captured by a categorical variable equal to $-1,0$, or 1 in each quarter depending on whether there was a loosening action, no change, or a tightening action in that quarter. The policy measure is purged of the variation in credit-to-GDP to address potential endogeneity concerns.

To understand the link between policies and CRE prices, a quantile regression model is used to assess the impact of policy measures on the $5^{\text {th }}$ percentile of the future distribution of CRE price changes. The baseline specification is as follows:

$$
\Delta_{h} Y_{i, t, \tau}=\alpha_{i, \tau}^{h}+\phi_{\tau}^{h} \Delta M P P_{i, t}+\gamma_{\tau}^{h} M P_{i, t}+\theta_{\tau}^{h} \text { Controls }_{i, t-1}+\epsilon_{i, t, \tau}^{h}
$$

where $\Delta_{h} Y_{i, t, \tau}$ denotes the (average) percentage change in real CRE prices in country $i$ from $t$ to $t+h(h=1,2, \ldots, 16)$, at quantile $\tau$ (e.g., $5^{\text {th }}$ percentile). $\Delta M P P_{i, t}$ is the change in macroprudential policy stance and $M P_{i, t}$ is the monetary policy shock. The monetary policy shock is measured by the predicted residual from regressing the policy rate on contemporaneous and lagged variables and a quadratic time trend as in Iacoviello and Navarro (2019). For some countries (US, Euro Area, UK, Japan, Switzerland, Canada, Australia, New Zealand), shadow rates are used to estimate the monetary policy shock to capture the unconventional monetary policy. ${ }^{32}$ In line with the specification used in Section III, Controls $_{i, t-1}$ is a set of covariates including lagged real GDP growth, changes in credit-to-GDP ratio, capital inflows to GDP ratio, the VIX index, and CRE price misalignment. $\alpha_{i}^{h}$ are country fixed effects.

The impact of macroprudential policies may also depend on the contemporaneous level of CRE price misalignment. To better understand this relationship, we interact CRE price misalignment with the categorical variable for changes in CRE-specific macroprudential policy, $\triangle M P P_{i, t}$, and estimate the specification below:

$$
\begin{gathered}
\Delta_{h} Y_{i, t, \tau}=\alpha_{i, \tau}^{h}+\phi_{\tau}^{h} \Delta M P P_{i, t}+\sigma_{\tau}^{h} \Delta M P P_{i, t} x \text { CRE Price Misalignment } t_{i, t}+\gamma_{\tau}^{h} M P_{i, t}+\theta_{\tau}^{h} \text { Controls }_{i, t-1} \\
+\epsilon_{i, t, \tau}^{h}, \quad(12)
\end{gathered}
$$

Our coefficients of interest are $\phi_{\tau}^{h}$ and $\sigma_{\tau}^{h}$, which identify the baseline impact of CRE-specific measures and their interaction effect with CRE price misalignment. Intuitively, a positive coefficient $\sigma_{\tau}^{h}$ implies that policy interventions are more effective when CRE prices diverge more from their fundamental value. Thus, we can compute the overall impact of macroprudential

\footnotetext{
${ }^{31}$ The number of macroprudential measures directly targeting the CRE sector has been limited. Hence assessments of their effectiveness are rare. There are a few exceptions. Duca and Ling (2020), for example, show that the tightening of effective capital requirements on CMBS in the United States following the Dodd-Frank Act helped prevent sharp declines in CRE risk premiums after the global financial crisis. Bassett and Marsh (2017) find that the 2006 US CRE lending guidance for banks with a high CRE concentration reduced CRE lending.

${ }^{32}$ The shadow rates are available on https://www.ljkmfa.com/test-test/international-ssrs/.
} 
policies on future CRE price growth depending on the level of price overvaluation in the sector at time $t$ using the estimated coefficients $\hat{\phi}_{\tau}^{h}$ and $\hat{\sigma}_{\tau}^{h}$.

Table 7 reports the full results from estimating baseline model in equation (11). Panel 1 in Figure 9 shows the estimated coefficients of CRE-Specific measures, $\widehat{\phi}_{\tau}^{h}$, from the same specification for each quarter $h$ of the forecasting horizon, which represents the marginal effect of a policy tightening. Hence, a positive coefficient indicates the extent to which policy tightening mitigates downside risks to CRE price growth.

Overall, the findings suggest that macroprudential policies have an important role in curtailing CRE sector vulnerabilities. Quantitatively, a tightening of targeted CRE measures reduces downside risks to CRE price growth by 0.3 percentage points per quarter in the near term (over 8 quarters). Economically, this result implies that a macroprudential tightening targeted to CRE vulnerabilities two years before the global financial crisis would have reduced on average the decline in CRE prices from about 11 percent to 8.5 percent.

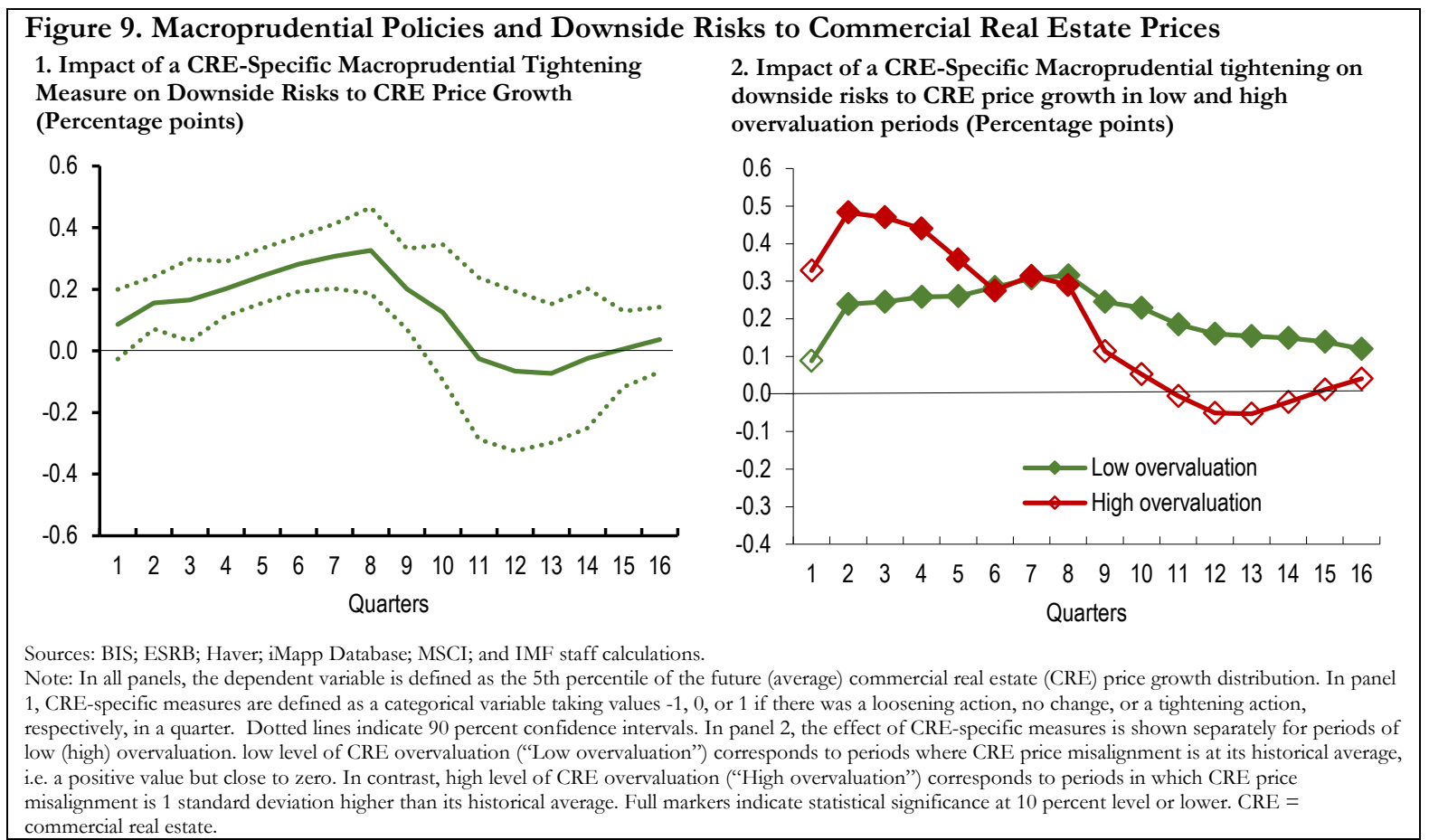

Although the overall effect of CRE-targeted measures appears to be more prominent in the shortand medium-term (up to ten-quarters-ahead), different types of measures may have a different time horizon over which they are effective. To see this, we replace the categorical variable identifying CRE-specific measures in equation (11) with two categorical variables identifying borrower-based and capital-based measures targeting both CRE markets. As before, policy variables are purged of variations in the credit-to-GDP ratio. Table 8 reports the estimation results. 
Overall, we find that borrower-based measures have a larger effect in the near-term. ${ }^{33}$ In contrast, capital-based measures have a larger effect after eight quarters. For example, twelve quarter ahead, the per-quarter impact of capital-based measures on the lower tail of CRE prices growth is equal to 0.35 percentage points, while the impact of borrower-based measures is not significant. Capitalbased policies are therefore more long-lasting than borrower-based macroprudential measures, but their effect takes more time to materialize.

Conceptually, macroprudential policies can mitigate the negative effects of CRE price corrections on the real economy through different channels. On one hand, borrower-based measures like LTV ratio constraints limits credit to new credit-worthy borrowers, which reduces the risk of default and curbs excessive credit growth. On the other hand, capital-based measures increase lenders' loss absorbency and enhance banks' resilience to loan defaults in CRE. ${ }^{34}$ The appropriate choice of macroprudential tools should therefore be contingent on the source and the intensity of the identified vulnerabilities.

Table 9 reports the results estimating equation (12). Panel 2 in Figure 9 plots the sum of the estimated coefficients $\widehat{\phi}_{\tau}^{h}$ and $\hat{\sigma}_{\tau}^{h}$ (corresponding to the overall impact of macroprudential policy measure on $\Delta_{h} Y_{i, t, \tau}$ ) in two different scenarios with varying CRE overvaluation. The first scenario with low levels of CRE overvaluation ("Low overvaluation") corresponds to periods where CRE price misalignment is at the historical average. In contrast, the alternative scenario with high levels of CRE overvaluation ("High overvaluation") correspond to periods in which CRE price misalignment is one standard deviation higher than the historical average.

We find that macroprudential policies have the largest effect on curbing downside risk to CRE price growth during high overvaluation periods, but that the effect diminishes in the long-term. In fact, the effect of CRE-specific measures is more long-lasting when macroprudential policies are introduced during the early build-up phase of vulnerabilities. A tightening of CRE-specific measures in periods of low overvaluation can lower CRE price declines after three years by about 0.2 percentage points (per quarter) more than in periods of high overvaluation.

Overall, these findings support the idea that tools aimed at increasing buffers should be deployed when risks are still building up. When the market has already entered a downswing, it may be too late to tighten to prevent large price drops. More broadly, beyond the level of CRE price misalignments, the sequencing and calibration of policy tools should also consider (i) the potential

\footnotetext{
${ }^{33}$ Beyond CRE-specific measures, borrower-based measures targeting residential real estate can affect the CRE market directly by limiting a borrower's access to credit for multifamily housing (such as apartments). They can also affect downside risks to CRE markets by dampening the amplification effects from the interaction between residential and commercial real estate prices that threaten financial stability. Unreported results using a similar identification strategy confirm indeed that borrower-based measures that include measures targeting the residential segment tend to have a significant impact, with a tightening reducing downside risks to CRE prices by about 2 percentage points (cumulative) in the medium and long terms.

${ }^{34}$ Beyond these transmission channels, our analysis highlights that macroprudential policies affect downside risks to CRE prices also by limiting CRE price misalignment (Annex A4.2). A possible explanation is that tightening of the borrowing limits and higher risk weights, if credible and large enough, can lead CRE investors to revise down their expectations of future CRE prices and thereby reduce speculative incentives that play a key role in bubble dynamics.
} 
capital shortfall and extra capital needed to maintain investors' confidence during stress periods; (ii) the uncertainty surrounding the estimation of corporate credit losses; (iii) the level of corporate indebtedness; and (iv) risks of policy leakage and the role of non-bank financial institutions. ${ }^{35}$

\section{ConClusion}

The commercial real estate sector has been severely affected by the COVID-19 crisis, with transaction volumes and prices falling globally in 2020, especially in some segments such as retail, hotels, and offices. Historically, the large size of the sector, its heavy reliance on debt funding, and its strong interconnectedness with the real economy has made it a source and amplifier of adverse macro-financial shocks, warranting enhanced supervisory attention. Our paper is the first to quantify downside tail risks arising from the commercial real estate market and to examine the effectiveness of macroprudential policy tools to mitigate such risks in a large sample of economies.

Using a novel approach to assess CRE market fair values, we find that the gap between the observed prices and the model-implied fair value increased in 2020 following a large drop in aggregate demand and net operating income. While some of the factors driving the shock to CRE market fundamentals were conjunctural, others indicate underlying structural changes in the CRE market and the economy at large. This is particularly true for the retail segment, where the demand for traditional brick-and-mortar retail has been eroding even before the pandemic as consumers shifted increasingly toward e-commerce.

Second, we show that CRE price misalignments are relevant for financial stability since they increase the probability of a large CRE price correction and affect macro-financial outcomes. For example, an increase in commercial real estate price misalignment is associated with an increase in downside risk to GDP growth in the near- and medium term, although the impact is smaller and statistically weaker for emerging market economies relative to advanced economies. We also find that the effect of CRE price misalignments on future GDP growth is amplified in the presence of underlying financial vulnerabilities, such as firms' financial leverage and cross-border capital inflows.

Finally, the outlook for the highly procyclical CRE sector is closely tied to the broader economic recovery, but also to the pandemic-induced structural changes in the sector. As the CRE market recovers, there is a risk that persistently easy financial conditions may contribute to an increase in vulnerabilities and price misalignments. The analysis in this paper suggests that targeted macroprudential policy tools, such as limits on the LTV and DSTI ratios and CRE-specific riskweights, can help address such vulnerabilities.

\footnotetext{
${ }^{35}$ Macroprudential measures are indeed generally applicable to domestic banks. They could be circumvented if CRE debt funding occurs by borrowing directly from abroad or through nonbank financial institutions. While there are not many examples of measures targeting NBFIs, in some cases, borrowing from abroad has been limited through capital flow management measures restricting investments by nonresidents through, for example, ownership restrictions on nonresidents, or higher stamp duties for nonresidents on purchases of real estate. The analysis considering the effect of such measures on CRE prices is reported in Annex A4.3.
} 


\section{References}

Adrian, T., Boyarchenko, N. and Giannone, D., 2019. "Vulnerable growth". American Economic Review, 109(4), pp.1263-89.

Adrian, T., Grinberg, F., Liang, N. and Malik, S., 2018. "The term structure of growth-at-risk". International Monetary Fund.

Aizenman, J. and Jinjarak, Y. 2009, "Current Account Patterns and National Real Estate Markets”, Journal of Urban Economics, Vol. 66(2), pp. 75-89.

Alam, Zohair, Mr Adrian Alter, Jesse Eiseman, Mr RG Gelos, Mr Heedon Kang, Mr Machiko Narita, Erlend Nier, and Naixi Wang. 2019. "Digging deeper--Evidence on the effects of macroprudential policies from a new database". International Monetary Fund, Washington, DC.

Barajas, A., Choi, W.G., Gan, K.Z., Guérin, P., Mann, S., Wang, M. and Xu, Y., 2021. "Loose Financial Conditions, Rising Leverage, and Risks to Macro-Financial Stability”. IMF Working Papers, 2021(222).

Bassett, W.F. and Marsh, W.B., 2017. "Assessing targeted macroprudential financial regulation: the case of the 2006 commercial real estate guidance for banks". Journal of Financial Stability, 30, pp.209-228.

Brandao-Marques, M.L., Chen, Q., Raddatz, C., Vandenbussche, J. and Xie, P., 2019. "The riskiness of credit allocation and financial stability”. International Monetary Fund. Working Paper No. 19/207.

Baumeister, Christiane. and James D. Hamilton. 2018. "Inference in Structural Vector Autoregressions When the Identifying Assumptions are Not Fully Believed: Re-evaluating the Role of Monetary Policy in Economic Fluctuations." Journal of Monetary Economics 100: 48-65.

2015. "Sign Restrictions, Structural Vector Autoregressions, and Useful Prior Information." Econometrica 83 (5): 1963-1999.

Brueckner, J., Kahn, M.E. and Lin, G.C., 2021. "A New Spatial Hedonic Equilibrium in the Emerging Work-from-Home Economy?” (No. w28526). National Bureau of Economic Research.

Campbell, S.D., Davis, M.A., Gallin, J. and Martin, R.F., 2009. "What moves housing markets: A variance decomposition of the rent-price ratio". Journal of Urban Economics, 66(2), pp.90-102.

Campbell, John, and Robert Shiller. 1989. "The Dividend Ratio Model and Small Sample Bias: A Monte Carlo Study.” Economics Letters, 29 (4): 325-331.

Canay, Ivan A. 2011. “A Simple Approach to Quantile Regression for Panel Data." The Econometrics Journal 14 (3): 368-386.

Chaney, Thomas, David Sraer and David Thesmar. 2012. "The Collateral Channel: How real Estate Shocks Affect Corporate Investment.” American Economic Review, 102 (6): 2381-2409.

Chernozhukov, Victor. 2002. "Inference for Extremal Conditional Quantile Models (Extreme Value Inference for Quantile Regression)." Unpublished Manuscript.

Chichernea, D., Miller, N., Fisher, J., Sklarz, M. and White, B., 2008. "A cross-sectional analysis of cap rates by msa". Journal of Real Estate Research, 30(3), pp.249-292.

Clayton, J., Ling, D.C. and Naranjo, A., 2009. "Commercial real estate valuation: fundamentals versus investor sentiment". The Journal of Real Estate Finance and Economics, 38(1), pp.5-37.

Cushman and Wakefield, 2021. "Q1 2021 U.S. Office Marketbeat” U.S. Office Marketbeat Reports.

Cushman and Wakefield, 2016. "The Great wall of Money”. Cushman \& Wakefield Capital Markets Research Publication.

Davis, M.A., Larson, W.D., Oliner, S.D. and Shui, J., 2021. “The price of residential land for counties, ZIP codes, and census tracts in the United States". Journal of Monetary Economics, 118, pp.413-431. 
Deghi, A., Katagiri, M., Shahid, M.S. and Valckx, N., 2020. "Predicting Downside Risks to House Prices and Macro-Financial Stability". International Monetary Fund. Working Paper No. 20/11.

Duca, J.V. and Ling, D.C., 2020. "The other (commercial) real estate boom and bust: the effects of risk premia and regulatory capital arbitrage”. Journal of Banking \& Finance, 112, p.105317.

Ellis, L. and Naughtin, C., 2010. "Commercial property and financial stability-an international perspective”. RBA Bulletin, June, pp.25-30.

European Systemic Risk Board (ESRB) 2015. "Report on commercial real estate and financial stability in the EU". December 2015

European Systemic Risk Board (ESRB). 2018. "Report on Vulnerabilities in the EU Commercial Real Estate Sector.” Frankfurt am Main, Germany.

Fendoglu, Salih. 2021. "Commercial Real Estate and Financial Stability: Evidence from the US Banking Sector”. IMF Global Financial Stability Notes No 2021/001.

Fernandez, Andrés, Michael W. Klein, Alessandro Rebucci, Martin Schindler, and Martín Uribe. 2017. "Capital Control Measures: A New Dataset." IMF Economic Review, 64 (3).

Fratzscher, M. 2012, "Capital Flows, Push Versus Pull Factors and the Global Financial Crisis", Journal of International Economics, Vol. 88, pp. 341-356.

Hale Thomas, Angrist Noam, Goldszmidt Rafael, Kira Beatriz, Petherick Anna, Phillips Toby, Webster Samuel, Cameron-Blake Emily, Hallas Laura, Majumdar Saptarshi, and Tatlow Helen. 2021. "A global panel database of pandemic policies (Oxford COVID-19 Government Response Tracker)." Nature HumanBehaviour. https://doi.org/10.1038/s41562-021-01079-8.

https://www.bsg.ox.ac.uk/research/research-projects/covid-19-government-response-tracker.

Hendershott, P.H. and MacGregor, B.D., 2005. Explaining UK Office and Retail Capitalization Rates Using an Error Correction Model. Real Estate Economics, 33, pp.299-322.

Iacoviello, Matteo and Gaston Navarro. 2019. "Foreign Effects of Higher U.S. Interest Rates." Journal of International Money and Finance 95 (C): 232-250.

IPF. 2017. "Changing Sources of Real Estate Debt Capital: Facts and Implications" IPF Research Program. Full Report

Machado, J.A. and Silva, J.S., 2019. "Quantiles via moments". Journal of Econometrics, 213(1), pp.145-173.

Nareit. 2019. "Estimating the Size of the Commercial Real Estate Market.” Nareit Research (July). https:// www reit .com/

sites/ default/ files/ Size \%20of \%20CRE \%20market \%202019\%20full .pdf.

Olszewski, K., 2013. "The commercial real estate market, central bank monitoring and macroprudential policy”. Review of Economic Analysis, 5(2), pp.213-250.

Panagopoulos Y, Vlamis P. 2009. "Real estate information technology: Bank lending, real estate bubbles, and Basel II". Journal of Real Estate Literature;17(2):293-310.

Shibut, L. and Singer, R., 2015. "Loss Given Default for Commercial Loans at Failed Banks". FDIC Center for Financial Research Paper, (2015-06).

Van Nieuwerburgh, S., 2019. "Why are REITs currently so expensive?”. RealEstate Economics, 47(1), pp.1865. 


\section{TABLES}

Table 1. Descriptive Statistics

\begin{tabular}{|c|c|c|c|c|c|}
\hline Variable & Mean & SD & Min & Max & Observations \\
\hline CRE price growth & 0.53 & 1.85 & -20.78 & 8.37 & 1,836 \\
\hline House prices growth & 0.58 & 1.97 & -14.11 & 14.08 & 1,836 \\
\hline Credit growth & 0.43 & 1.85 & -9.41 & 28.77 & 1,836 \\
\hline GDP growth & 0.58 & 1.15 & -6.48 & 20.89 & 1,836 \\
\hline Financial conditions index & 0.05 & 0.72 & -1.83 & 4.06 & 1,836 \\
\hline Credit-to-GDP gap & 1.55 & 17.92 & -99.70 & 87.20 & 1,836 \\
\hline Capital Flow-to-GDP & 0.02 & 6.74 & -79.36 & 32.13 & 1,836 \\
\hline VIX & 19.24 & 7.63 & 10.12 & 51.72 & 1,836 \\
\hline Capitalization rate (nominal) & 5.77 & 1.42 & 2.20 & 10.11 & 1,757 \\
\hline CRE price misalignment & 0.00 & 0.10 & -0.57 & 0.69 & 1,757 \\
\hline Total return & 1.97 & 1.78 & -17.70 & 9.54 & 1,757 \\
\hline $3 \mathrm{~m}$ interest rate & 2.60 & 2.40 & -0.81 & 12.00 & 1,699 \\
\hline NOl growth & -0.46 & 4.07 & -50.55 & 76.56 & 1,598 \\
\hline Monetary policy shock & 0.00 & 0.29 & -1.52 & 1.35 & 1,793 \\
\hline CRE-specific macroprudential policy & 0.00 & 0.11 & -0.99 & 1.01 & 1,793 \\
\hline Borrower-based macroprudential policy & 0.01 & 1.15 & -4.60 & 6.67 & 1,793 \\
\hline CFM Overall Inflow Restriction Shock & 0.01 & 0.21 & -1.11 & 1.00 & 1,568 \\
\hline CFM Real-estate Inflow Restriction Shock & 0.00 & 0.17 & -1.04 & 1.07 & 1,568 \\
\hline
\end{tabular}

Authors' calculations. 
Table 2. Commercial Real Estate Prices-at-Risk (CaR)

\begin{tabular}{|c|c|c|c|c|c|c|c|c|c|c|c|c|c|c|c|c|}
\hline VARIABLES & $h=1$ & $h=2$ & $h=3$ & $h=4$ & $h=5$ & $h=6$ & $h=7$ & $h=8$ & $h=9$ & $h=10$ & $h=11$ & $h=12$ & $h=13$ & $h=14$ & $h=15$ & $h=16$ \\
\hline \multirow[t]{2}{*}{ GDP growth } & $0.175^{*}$ & $0.174^{* \star}$ & 0.104 & 0.178 & 0.177 & 0.086 & 0.072 & 0.024 & 0.042 & 0.045 & 0.017 & -0.003 & -0.006 & -0.016 & -0.046 & -0.039 \\
\hline & $(0.101)$ & $(0.081)$ & $(0.144)$ & $(0.138)$ & (0.113) & $(0.109)$ & $(0.125)$ & $(0.111)$ & $(0.097)$ & $(0.148)$ & $(0.110)$ & $(0.103)$ & $(0.089)$ & $(0.111)$ & (0.108) & $(0.049)$ \\
\hline \multirow[t]{2}{*}{$\mathrm{FCl}$ conditions index } & $-0.244^{* *}$ & $-0.146^{* *}$ & $-0.140^{\star *}$ & -0.093 & -0.070 & -0.010 & -0.022 & -0.019 & -0.030 & 0.001 & -0.002 & 0.007 & 0.002 & 0.006 & -0.011 & 0.015 \\
\hline & $(0.100)$ & $(0.073)$ & $(0.063)$ & $(0.093)$ & (0.104) & $(0.088)$ & $(0.073)$ & $(0.067)$ & $(0.056)$ & $(0.072)$ & $(0.055)$ & $(0.038)$ & $(0.042)$ & $(0.049)$ & $(0.047)$ & $(0.033)$ \\
\hline \multirow[t]{2}{*}{ Capital Flow-to-GDP } & $-0.338^{\star}$ & $-0.473^{* * *}$ & $-0.449^{\star * *}$ & $-0.534^{\star \star \star}$ & $-0.554^{* * *}$ & $-0.581^{* * *}$ & $-0.626^{\star \star \star}$ & $-0.562^{\star \star \star}$ & $-0.516^{\star \star *}$ & $-0.471^{* \star *}$ & $-0.411^{* * *}$ & $-0.362^{* \star *}$ & $-0.385^{\star \star \star}$ & $-0.445^{\star * *}$ & $-0.347^{\star \star \star}$ & $-0.281^{* * *}$ \\
\hline & $(0.175)$ & $(0.151)$ & $(0.156)$ & $(0.155)$ & $(0.191)$ & $(0.118)$ & $(0.126)$ & $(0.112)$ & $(0.146)$ & $(0.084)$ & $(0.112)$ & $(0.075)$ & $(0.097)$ & $(0.093)$ & $(0.088)$ & $(0.069)$ \\
\hline \multirow[t]{2}{*}{ Credit-to-GDP growth } & $-0.439^{\star \star \star}$ & $-0.438^{\star \star *}$ & $-0.384^{\star \star *}$ & $-0.397^{\star \star \star}$ & $-0.397^{\star \star *}$ & $-0.289^{* \star}$ & -0.225 & $-0.238^{\star \star \star}$ & $-0.260^{\star \star \star}$ & $-0.264^{* \star *}$ & $-0.256^{* *}$ & $-0.242^{* \star *}$ & $-0.221^{1 *}$ & $-0.212^{\star \star \star}$ & $-0.235^{\star \star \star}$ & $-0.258^{\star \star *}$ \\
\hline & $(0.106)$ & $(0.079)$ & $(0.120)$ & $(0.106)$ & $(0.117)$ & $(0.142)$ & $(0.139)$ & $(0.082)$ & $(0.074)$ & $(0.092)$ & $(0.113)$ & $(0.090)$ & $(0.112)$ & $(0.071)$ & $(0.091)$ & $(0.070)$ \\
\hline \multirow[t]{2}{*}{ CRE price misalignment } & $-0.346^{* \star \star}$ & $-0.487^{\star \star \star}$ & $-0.572^{\star \star \star}$ & $-0.578^{\star \star \star}$ & $-0.593^{\star \star *}$ & $-0.523^{* \star \star}$ & $-0.561^{\star \star \star}$ & $-0.577^{\star \star \star}$ & $-0.639^{\star \star \star *}$ & $-0.685^{\star \star \star}$ & $-0.658^{\star \star \star}$ & $-0.648^{* \star *}$ & $-0.638^{\star \star \star}$ & $-0.604^{\star \star \star}$ & $-0.635^{\star \star \star}$ & $-0.647^{\star \star \star}$ \\
\hline & $(0.068)$ & $(0.099)$ & $(0.115)$ & $(0.121)$ & $(0.130)$ & $(0.107)$ & $(0.143)$ & $(0.059)$ & $(0.114)$ & $(0.090)$ & $(0.104)$ & $(0.098)$ & $(0.078)$ & $(0.099)$ & $(0.106)$ & $(0.045)$ \\
\hline Country FE & YES & YES & YES & YES & YES & YES & YES & YES & YES & YES & YES & YES & YES & YES & YES & YES \\
\hline CRE price growth lag & YES & YES & YES & YES & YES & YES & YES & YES & YES & YES & YES & YES & YES & YES & YES & YES \\
\hline Observations & 1,845 & 1,818 & 1,790 & 1,762 & 1,734 & 1,706 & 1,676 & 1,646 & 1,616 & 1,586 & 1,556 & 1,526 & 1,496 & 1,466 & 1,436 & 1,406 \\
\hline
\end{tabular}

Note: The tables report the estimated coefficients from the CRE Prices-at-Risk specification described in equation (7). The models are estimated using the full sample of core economies. The dependent variable corresponds to the $5^{\text {th }}$ percentile of the average CRE price growth distribution over the forecasting horizon $\mathrm{h}$. All covariates are standardized so that magnitudes of coefficients indicate relative importance of variables. Standard errors are bootstrapped and shown in parentheses. ${ }^{* * *} p<0.01, * * p<0.05, * p<0.1$. 
Table 3. Growth-at-Risk with CRE Price Misalignment (Full Sample)

\begin{tabular}{|c|c|c|c|c|c|c|c|c|c|c|c|c|c|c|c|c|}
\hline VARIABLES & $h=1$ & $h=2$ & $\mathrm{~h}=3$ & $\mathrm{~h}=4$ & $h=5$ & $\mathrm{~h}=6$ & $h=7$ & $h=8$ & $h=9$ & $h=10$ & $h=11$ & $h=12$ & $h=13$ & $h=14$ & $h=15$ & $h=16$ \\
\hline CRE price Misalignment & $\begin{array}{c}-0.423^{\star * *} \\
(0.069)\end{array}$ & $\begin{array}{c}-0.372^{* \star *} \\
(0.058)\end{array}$ & $\begin{array}{c}-0.331^{\star * *} \\
(0.041)\end{array}$ & $\begin{array}{c}-0.311^{* * *} \\
(0.040)\end{array}$ & $\begin{array}{c}-0.271^{\star \star *} \\
(0.028)\end{array}$ & $\begin{array}{c}-0.280^{* \star *} \\
(0.028)\end{array}$ & $\begin{array}{c}-0.230^{* \star *} \\
(0.033)\end{array}$ & $\begin{array}{c}-0.212^{\star * *} \\
(0.030)\end{array}$ & $\begin{array}{c}-0.197^{* * *} \\
(0.039)\end{array}$ & $\begin{array}{c}-0.180^{* * *} \\
(0.029)\end{array}$ & $\begin{array}{c}-0.148^{* * *} \\
(0.040)\end{array}$ & $\begin{array}{c}-0.163^{\star * *} \\
(0.033)\end{array}$ & $\begin{array}{c}-0.167^{\star \star \star} \\
(0.027)\end{array}$ & $\begin{array}{c}-0.171^{\star * \star} \\
(0.023)\end{array}$ & $\begin{array}{c}-0.178^{\star \star *} \\
(0.029)\end{array}$ & $\begin{array}{c}-0.187^{* * *} \\
(0.025)\end{array}$ \\
\hline GDP growth & $\begin{array}{l}-0.031 \\
(0.189)\end{array}$ & $\begin{array}{c}0.031 \\
(0.128)\end{array}$ & $\begin{array}{c}0.083 \\
(0.078)\end{array}$ & $\begin{array}{l}-0.086 \\
(0.099)\end{array}$ & $\begin{array}{l}-0.089 \\
(0.082)\end{array}$ & $\begin{array}{l}-0.077 \\
(0.079)\end{array}$ & $\begin{array}{l}-0.032 \\
(0.095)\end{array}$ & $\begin{array}{l}-0.029 \\
(0.097)\end{array}$ & $\begin{array}{l}-0.063 \\
(0.087)\end{array}$ & $\begin{array}{l}-0.098 \\
(0.066)\end{array}$ & $\begin{array}{l}-0.027 \\
(0.062)\end{array}$ & $\begin{array}{l}-0.076 \\
(0.078)\end{array}$ & $\begin{array}{l}-0.098 \\
(0.073)\end{array}$ & $\begin{array}{l}-0.045 \\
(0.045)\end{array}$ & $\begin{array}{l}-0.026 \\
(0.065)\end{array}$ & $\begin{array}{c}-0.042 \\
(0.054)\end{array}$ \\
\hline Financial conditions index & $\begin{array}{c}-0.399^{* * *} \\
(0.144)\end{array}$ & $\begin{array}{c}-0.242^{\star \star \star} \\
(0.070)\end{array}$ & $\begin{array}{l}-0.107 \\
(0.082)\end{array}$ & $\begin{array}{l}-0.116^{*} \\
(0.061)\end{array}$ & $\begin{array}{l}-0.082 \\
(0.055)\end{array}$ & $\begin{array}{l}-0.048 \\
(0.048)\end{array}$ & $\begin{array}{c}0.049 \\
(0.042)\end{array}$ & $\begin{array}{c}0.075 \\
(0.048)\end{array}$ & $\begin{array}{l}0.097^{\star *} \\
(0.041)\end{array}$ & $\begin{array}{l}0.091^{* *} \\
(0.042)\end{array}$ & $\begin{array}{c}0.094^{* * *} \\
(0.031)\end{array}$ & $\begin{array}{c}0.068 \\
(0.041)\end{array}$ & $\begin{array}{l}0.057^{\star *} \\
(0.027)\end{array}$ & $\begin{array}{l}0.066^{*} \\
(0.036)\end{array}$ & $\begin{array}{l}0.057^{*} \\
(0.030)\end{array}$ & $\begin{array}{l}0.040^{*} \\
(0.024)\end{array}$ \\
\hline Credit-to-GDP gap & $\begin{array}{c}-0.491^{* * *} \\
(0.131)\end{array}$ & $\begin{array}{c}-0.453^{\star \star *} \\
(0.093)\end{array}$ & $\begin{array}{c}-0.363^{* * *} \\
(0.117)\end{array}$ & $\begin{array}{c}-0.387^{\star \star *} \\
(0.080)\end{array}$ & $\begin{array}{c}-0.350^{* * *} \\
(0.062)\end{array}$ & $\begin{array}{c}-0.329^{\star \star *} \\
(0.044)\end{array}$ & $\begin{array}{c}-0.289^{* * *} \\
(0.048)\end{array}$ & $\begin{array}{c}-0.353^{* * *} \\
(0.050)\end{array}$ & $\begin{array}{c}-0.357^{\star * *} \\
(0.040)\end{array}$ & $\begin{array}{c}-0.346^{* * *} \\
(0.030)\end{array}$ & $\begin{array}{c}-0.315^{\star * *} \\
(0.028)\end{array}$ & $\begin{array}{c}-0.332^{* * *} \\
(0.036)\end{array}$ & $\begin{array}{c}-0.318^{\star \star *} \\
(0.038)\end{array}$ & $\begin{array}{c}-0.311^{\star * *} \\
(0.029)\end{array}$ & $\begin{array}{c}-0.288^{\star \star *} \\
(0.037)\end{array}$ & $\begin{array}{c}-0.257^{\star * \star} \\
(0.023)\end{array}$ \\
\hline House prices growth & $\begin{array}{l}0.266^{* *} \\
(0.106)\end{array}$ & $\begin{array}{l}0.321^{\star \star *} \\
(0.060)\end{array}$ & $\begin{array}{c}0.362^{\star \star *} \\
(0.092)\end{array}$ & $\begin{array}{c}0.339^{\star \star *} \\
(0.060)\end{array}$ & $\begin{array}{l}0.317^{\star \star *} \\
(0.041)\end{array}$ & $\begin{array}{c}0.296^{\star * *} \\
(0.043)\end{array}$ & $\begin{array}{l}0.264^{\star \star *} \\
(0.041)\end{array}$ & $\begin{array}{c}0.220^{\star \star *} \\
(0.027)\end{array}$ & $\begin{array}{c}0.228^{\star * *} \\
(0.032)\end{array}$ & $\begin{array}{c}0.227^{\star * *} \\
(0.021)\end{array}$ & $\begin{array}{c}0.178^{\star \star *} \\
(0.022)\end{array}$ & $\begin{array}{c}0.165^{\star \star *} \\
(0.028)\end{array}$ & $\begin{array}{c}0.156^{\star \star *} \\
(0.018)\end{array}$ & $\begin{array}{c}0.144^{* * *} \\
(0.024)\end{array}$ & $\begin{array}{c}0.123^{\star * *} \\
(0.025)\end{array}$ & $\begin{array}{c}0.126^{* * *} \\
(0.019)\end{array}$ \\
\hline Country FE & YES & YES & YES & YES & YES & YES & YES & YES & YES & YES & YES & YES & YES & YES & YES & YES \\
\hline GDP growth lag & YES & YES & YES & YES & YES & YES & YES & YES & YES & YES & YES & YES & YES & YES & YES & YES \\
\hline Observations & 1,792 & 1,792 & 1,785 & 1,757 & 1,730 & 1,703 & 1,676 & 1,648 & 1,620 & 1,592 & 1,564 & 1,536 & 1,508 & 1,480 & 1,452 & 1,424 \\
\hline
\end{tabular}

Note: The tables report the estimated coefficients from the Growth-at-Risk specification described in equation (9). The models are estimated using the full sample of core economies. The dependent variable corresponds to the $5^{\text {th }}$ percentile of the average GDP growth distribution over the forecasting horizon $\mathrm{h}$. All covariates are standardized so that magnitudes of coefficients indicate relative importance of variables. Standard errors are bootstrapped and shown in parentheses. ${ }^{* * *} \mathrm{p}<0.01,{ }^{*} \mathrm{p}<0.05,{ }^{*} \mathrm{p}<0.1$. 
Table 4. Growth-at-Risk with CRE Price Misalignment (Advanced Economies and Emerging Market Economies)

Advanced Economies

\begin{tabular}{|c|c|c|c|c|c|c|c|c|c|c|c|c|c|c|c|c|}
\hline VARIABLES & $h=1$ & $h=2$ & $h=3$ & $h=4$ & $h=5$ & $h=6$ & $h=7$ & $h=8$ & $h=9$ & $h=10$ & $h=11$ & $h=12$ & $h=13$ & $h=14$ & $h=15$ & $h=16$ \\
\hline CRE price Misalignment & $\begin{array}{c}-0.450^{\star \star \star \star} \\
(0.137)\end{array}$ & $\begin{array}{c}-0.476^{* * *} \\
(0.070)\end{array}$ & $\begin{array}{c}-0.412^{\star \star \star *} \\
(0.063)\end{array}$ & 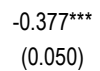 & $\begin{array}{c}-0.325^{\star \star *} \\
(0.030)\end{array}$ & $\begin{array}{c}-0.319^{* \star *} \\
(0.031)\end{array}$ & $\begin{array}{c}-0.270^{\star \star *} \\
(0.035)\end{array}$ & $\begin{array}{c}-0.239^{* * *} \\
(0.031)\end{array}$ & $\begin{array}{c}-0.232^{* * *} \\
(0.027)\end{array}$ & $\begin{array}{c}-0.210^{\star * *} \\
(0.039)\end{array}$ & $\begin{array}{c}-0.203^{* * *} \\
(0.039)\end{array}$ & 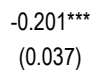 & $\begin{array}{c}-0.201^{* * *} \\
(0.026)\end{array}$ & $\begin{array}{c}-0.199^{\star * *} \\
(0.022)\end{array}$ & $\begin{array}{c}-0.197^{\star \star \star} \\
(0.022)\end{array}$ & $\begin{array}{c}-0.202^{* * *} \\
(0.019)\end{array}$ \\
\hline Financial conditions index & $\begin{array}{c}-0.437^{\star \star \star} \\
(0.132)\end{array}$ & $\begin{array}{c}-0.293^{\star *} \\
(0.116)\end{array}$ & $\begin{array}{c}-0.202^{*} \\
(0.109)\end{array}$ & $\begin{array}{c}-0.149^{*} \\
(0.077)\end{array}$ & $\begin{array}{c}-0.126^{\star * *} \\
(0.029)\end{array}$ & $\begin{array}{l}-0.087^{*} \\
(0.052)\end{array}$ & $\begin{array}{l}-0.010 \\
(0.045)\end{array}$ & $\begin{array}{c}0.046 \\
(0.044)\end{array}$ & $\begin{array}{l}0.070^{\star *} \\
(0.034)\end{array}$ & $\begin{array}{l}0.073^{* *} \\
(0.034)\end{array}$ & $\begin{array}{l}0.056^{*} \\
(0.031)\end{array}$ & $\begin{array}{l}0.037^{* *} \\
(0.018)\end{array}$ & $\begin{array}{c}0.035 \\
(0.025)\end{array}$ & $\begin{array}{c}0.024 \\
(0.019)\end{array}$ & $\begin{array}{c}0.019 \\
(0.014)\end{array}$ & $\begin{array}{c}0.008 \\
(0.014)\end{array}$ \\
\hline Credit-to-GDP gap & $\begin{array}{c}-0.504^{\star \star \star} \\
(0.178)\end{array}$ & $\begin{array}{c}-0.552^{* * *} \\
(0.156)\end{array}$ & $\begin{array}{c}-0.502^{\star * *} \\
(0.114)\end{array}$ & $\begin{array}{c}-0.383^{* * *} \\
(0.108)\end{array}$ & $\begin{array}{c}-0.370^{\star \star *} \\
(0.045)\end{array}$ & $\begin{array}{c}-0.318^{\star * *} \\
(0.051)\end{array}$ & $\begin{array}{c}-0.308^{\star * *} \\
(0.063)\end{array}$ & $\begin{array}{c}-0.351^{\star * *} \\
(0.060)\end{array}$ & $\begin{array}{c}-0.376^{* * *} \\
(0.052)\end{array}$ & $\begin{array}{c}-0.342^{\star \star *} \\
(0.038)\end{array}$ & $\begin{array}{c}-0.359^{* \star *} \\
(0.027)\end{array}$ & 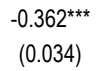 & $\begin{array}{c}-0.364^{\star * *} \\
(0.018)\end{array}$ & $\begin{array}{c}-0.349^{* * *} \\
(0.031)\end{array}$ & $\begin{array}{c}-0.334^{\star \star \star} \\
(0.026)\end{array}$ & $\begin{array}{c}-0.312^{* * *} \\
(0.022)\end{array}$ \\
\hline House prices growth & $\begin{array}{l}0.312^{\star *} \\
(0.149)\end{array}$ & $\begin{array}{l}0.308^{* *} \\
(0.130)\end{array}$ & $\begin{array}{c}0.158 \\
(0.110)\end{array}$ & $\begin{array}{c}0.313^{* \star \star} \\
(0.074)\end{array}$ & $\begin{array}{c}0.281^{\star \star \star} \\
(0.065)\end{array}$ & $\begin{array}{c}0.298^{\star \star *} \\
(0.052)\end{array}$ & $\begin{array}{c}0.245^{\star \star \star} \\
(0.076)\end{array}$ & $\begin{array}{c}0.185^{\star \star \star} \\
(0.057)\end{array}$ & $\begin{array}{c}0.193^{\star * *} \\
(0.035)\end{array}$ & $\begin{array}{c}0.217^{\star \star *} \\
(0.026)\end{array}$ & $\begin{array}{l}0.154^{\star \star *} \\
(0.032)\end{array}$ & $\begin{array}{c}0.136^{\star \star *} \\
(0.025)\end{array}$ & $\begin{array}{c}0.113^{* \star \star} \\
(0.023)\end{array}$ & $\begin{array}{c}0.092^{\star \star *} \\
(0.020)\end{array}$ & $\begin{array}{c}0.083^{* * *} \\
(0.020)\end{array}$ & $\begin{array}{c}0.072^{\star * *} \\
(0.015)\end{array}$ \\
\hline Country FE & YES & YES & YES & YES & YES & YES & YES & YES & YES & YES & YES & YES & YES & YES & YES & YES \\
\hline GDP growth lag & YES & YES & YES & YES & YES & YES & YES & YES & YES & YES & YES & YES & YES & YES & YES & YES \\
\hline Observations & 1,415 & 1,415 & 1,408 & 1,388 & 1,368 & 1,348 & 1,328 & 1,307 & 1,286 & 1,265 & 1,244 & 1,223 & 1,202 & 1,181 & 1,160 & 1,139 \\
\hline
\end{tabular}

Emerging Market Economies

\begin{tabular}{|c|c|c|c|c|c|c|c|c|c|c|c|c|c|c|c|c|}
\hline VARIABLES & $h=1$ & $h=2$ & $h=3$ & $h=4$ & $h=5$ & $h=6$ & $h=7$ & $h=8$ & $h=9$ & $h=10$ & $h=11$ & $h=12$ & $h=13$ & $h=14$ & $h=15$ & $h=16$ \\
\hline CRE price Misalignment & $\begin{array}{l}-0.290^{*} \\
(0.162)\end{array}$ & $\begin{array}{c}-0.102 \\
(0.203)\end{array}$ & $\begin{array}{l}-0.131 \\
(0.189)\end{array}$ & $\begin{array}{l}-0.174^{*} \\
(0.089)\end{array}$ & $\begin{array}{c}-0.242^{* *} \\
(0.103)\end{array}$ & $\begin{array}{c}-0.236^{* *} \\
(0.117)\end{array}$ & $\begin{array}{c}-0.211^{\star * *} \\
(0.061)\end{array}$ & $\begin{array}{c}-0.177^{\star *} \\
(0.079)\end{array}$ & $\begin{array}{l}-0.001 \\
(0.083)\end{array}$ & $\begin{array}{c}0.095 \\
(0.117)\end{array}$ & $\begin{array}{c}0.047 \\
(0.106)\end{array}$ & $\begin{array}{c}0.031 \\
(0.103)\end{array}$ & $\begin{array}{c}0.012 \\
(0.070)\end{array}$ & $\begin{array}{l}-0.001 \\
(0.070)\end{array}$ & $\begin{array}{c}0.007 \\
(0.077)\end{array}$ & $\begin{array}{c}-0.014 \\
(0.058)\end{array}$ \\
\hline Financial conditions index & $\begin{array}{l}-0.005 \\
(0.209)\end{array}$ & $\begin{array}{r}-0.053 \\
(0.268)\end{array}$ & $\begin{array}{c}-0.090 \\
(0.350)\end{array}$ & $\begin{array}{c}-0.258 \\
(0.209)\end{array}$ & $\begin{array}{l}-0.011 \\
(0.220)\end{array}$ & $\begin{array}{c}0.060 \\
(0.122)\end{array}$ & $\begin{array}{c}0.049 \\
(0.176)\end{array}$ & $\begin{array}{c}0.122 \\
(0.102)\end{array}$ & $\begin{array}{l}0.192^{\star *} \\
(0.091)\end{array}$ & $\begin{array}{c}0.286^{*} \\
(0.164)\end{array}$ & $\begin{array}{l}0.198^{\star *} \\
(0.091)\end{array}$ & $\begin{array}{c}0.195 \\
(0.155)\end{array}$ & $\begin{array}{l}0.194^{* *} \\
(0.097)\end{array}$ & $\begin{array}{l}0.164^{\star *} \\
(0.072)\end{array}$ & $\begin{array}{c}0.118 \\
(0.100)\end{array}$ & $\begin{array}{c}0.130 \\
(0.102)\end{array}$ \\
\hline Credit-to-GDP gap & $\begin{array}{c}-0.821^{* *} \\
(0.376)\end{array}$ & $\begin{array}{c}-0.551 \\
(0.398)\end{array}$ & $\begin{array}{l}-0.018 \\
(0.432)\end{array}$ & $\begin{array}{l}-0.468^{*} \\
(0.255)\end{array}$ & $\begin{array}{c}-0.686^{* * *} \\
(0.239)\end{array}$ & $\begin{array}{c}-0.832^{* * *} \\
(0.250)\end{array}$ & $\begin{array}{c}-0.777^{\star * *} \\
(0.208)\end{array}$ & $\begin{array}{c}-0.671^{\star * *} \\
(0.192)\end{array}$ & $\begin{array}{c}-0.563^{* * *} \\
(0.157)\end{array}$ & $\begin{array}{c}-0.615^{\star \star \star} \\
(0.129)\end{array}$ & $\begin{array}{c}-0.594^{\star * *} \\
(0.192)\end{array}$ & 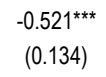 & $\begin{array}{c}-0.497^{* \star *} \\
(0.143)\end{array}$ & $\begin{array}{c}-0.514^{\star \star *} \\
(0.073)\end{array}$ & $\begin{array}{c}-0.508^{\star \star \star} \\
(0.095)\end{array}$ & $\begin{array}{c}-0.499^{\star * \star} \\
(0.085)\end{array}$ \\
\hline House prices growth & $\begin{array}{c}0.292^{\star} \\
(0.158)\end{array}$ & $\begin{array}{c}0.410 \\
(0.285)\end{array}$ & $\begin{array}{l}0.587^{\star \star} \\
(0.232)\end{array}$ & $\begin{array}{c}0.425^{\star \star \star} \\
(0.116)\end{array}$ & $\begin{array}{l}0.303^{* *} \\
(0.150)\end{array}$ & $\begin{array}{c}0.023 \\
(0.228)\end{array}$ & $\begin{array}{c}0.056 \\
(0.159)\end{array}$ & $\begin{array}{l}-0.011 \\
(0.191)\end{array}$ & $\begin{array}{c}0.165 \\
(0.127)\end{array}$ & $\begin{array}{l}0.331^{\text {}} \\
(0.130)\end{array}$ & $\begin{array}{c}0.091 \\
(0.160)\end{array}$ & $\begin{array}{c}0.041 \\
(0.144)\end{array}$ & $\begin{array}{c}0.045 \\
(0.066)\end{array}$ & $\begin{array}{l}0.118^{\star} \\
(0.068)\end{array}$ & $\begin{array}{l}0.193^{*} \\
(0.108)\end{array}$ & $\begin{array}{l}0.201^{\star} \\
(0.110)\end{array}$ \\
\hline Country FE & YES & YES & YES & YES & YES & YES & YES & YES & YES & YES & YES & YES & YES & YES & YES & YES \\
\hline GDP growth lag & YES & YES & YES & YES & YES & YES & YES & YES & YES & YES & YES & YES & YES & YES & YES & YES \\
\hline Observations & 377 & 377 & 377 & 369 & 362 & 355 & 348 & 341 & 334 & 327 & 320 & 313 & 306 & 299 & 292 & 285 \\
\hline
\end{tabular}

Note: The tables report the estimated coefficients from the Growth-at-Risk specification described in equation (9) separately for the sample of advanced and emerging market economies. The dependent variable corresponds to the $5^{\text {th }}$ percentile of the average GDP growth distribution over the forecasting horizon $\mathrm{h}$. All covariates are standardized so that magnitudes of coefficients indicate relative importance of variables. Standard errors are bootstrapped and shown in parentheses. ${ }^{* * *} \mathrm{p}<0.01,{ }^{* *} \mathrm{p}<0.05,{ }^{*} \mathrm{p}<0.1$. 
Table 5. Amplification effect of CRE Price Misalignment on Growth-at-Risk through Credit-to-GDP Gap

\begin{tabular}{|c|c|c|c|c|c|c|c|c|c|c|c|c|c|c|c|c|}
\hline Scenario with Average Leverage & $h=1$ & $h=2$ & $h=3$ & $h=4$ & $h=5$ & $h=6$ & $h=7$ & $h=8$ & $h=9$ & $h=10$ & $h=11$ & $h=12$ & $h=13$ & $h=14$ & $h=15$ & $h=16$ \\
\hline $\begin{array}{l}\text { Effect of CRE price misalignment } \\
\text { with average credit-to-GDP gap } \\
\left(\hat{\beta}_{\tau}^{h}\right)\end{array}$ & $\begin{array}{l}-0.404^{\star \star *} \\
(0.094) \\
\end{array}$ & $\begin{array}{l}-0.458^{\star \star \star} \\
(0.065) \\
\end{array}$ & $\begin{array}{l}-0.416^{* \star *} \\
(0.047) \\
\end{array}$ & $\begin{array}{l}-0.384^{* \star *} \\
(0.074)\end{array}$ & $\begin{array}{l}-0.312^{* * \star} \\
(0.062)\end{array}$ & $\begin{array}{l}-0.326^{* \star *} \\
(0.056)\end{array}$ & $\begin{array}{l}-0.279^{\star \star *} \\
(0.052) \\
\end{array}$ & $\begin{array}{l}-0.233^{* * *} \\
(0.035)\end{array}$ & $\begin{array}{l}-0.210^{* \star *} \\
(0.037)\end{array}$ & $\begin{array}{l}-0.158^{\star \star \star} \\
(0.045)\end{array}$ & $\begin{array}{l}-0.139^{\star \star *} \\
(0.034)\end{array}$ & $\begin{array}{l}-0.132^{* *} \\
(0.053)\end{array}$ & $\begin{array}{l}-0.121^{\star \star \star} \\
(0.037) \\
\end{array}$ & $\begin{array}{l}-0.119^{* \star *} \\
(0.041)\end{array}$ & $\begin{array}{l}-0.132^{\star \star \star} \\
(0.034)\end{array}$ & $\begin{array}{l}-0.132^{\star * \star} \\
(0.036)\end{array}$ \\
\hline Scenario with High Leverage & $h=1$ & $h=2$ & $h=3$ & $h=4$ & $\mathrm{~h}=5$ & $h=6$ & $h=7$ & $h=8$ & $h=9$ & $h=10$ & $h=11$ & $h=12$ & $h=13$ & $\mathrm{~h}=14$ & $h=15$ & $h=16$ \\
\hline $\begin{array}{l}\text { Effect of CRE price misalignment } \\
\text { with high Credit-to-GDP gap } \\
\left(\hat{\beta}_{\tau}^{h}+\hat{\lambda}_{\tau}^{h}\right)\end{array}$ & $\begin{array}{l}-0.582^{* * *} \\
(0.109) \\
\end{array}$ & $\begin{array}{l}-0.597^{\star \star *} \\
(0.0751)\end{array}$ & $\begin{array}{l}-0.551^{\star \star \star} \\
(0.0693)\end{array}$ & $\begin{array}{l}-0.475^{* \star *} \\
(0.094)\end{array}$ & $\begin{array}{l}-0.391^{\star \star *} \\
(0.0715)\end{array}$ & $\begin{array}{l}-0.404^{\star \star *} \\
(0.0633)\end{array}$ & $\begin{array}{l}-0.365^{\star * *} \\
(0.059) \\
\end{array}$ & $\begin{array}{l}-0.301^{* * *} \\
(0.0428)\end{array}$ & $\begin{array}{l}-0.28^{* \star *} \\
(0.0364)\end{array}$ & $\begin{array}{l}-0.24^{* \star \star} \\
(0.0432)\end{array}$ & $\begin{array}{l}-0.229^{\star \star *} \\
(0.036)\end{array}$ & $\begin{array}{l}-0.221^{* * *} \\
(0.0613)\end{array}$ & $\begin{array}{l}-0.206^{* \star *} \\
(0.0417)\end{array}$ & $\begin{array}{l}-0.185^{* * *} \\
(0.0392)\end{array}$ & $\begin{array}{l}-0.182^{* * *} \\
(0.0369)\end{array}$ & $\begin{array}{l}-0.173^{* * *} \\
(0.0388) \\
\end{array}$ \\
\hline Country FE & YES & YES & YES & YES & YES & YES & YES & YES & YES & YES & YES & YES & YES & YES & YES & YES \\
\hline CRE price growth lag & YES & YES & YES & YES & YES & YES & YES & YES & YES & YES & YES & YES & YES & YES & YES & YES \\
\hline Macro Controls & YES & YES & YES & YES & YES & YES & YES & YES & YES & YES & YES & YES & YES & YES & YES & YES \\
\hline Observations & 1,792 & 1,792 & 1,785 & 1,757 & 1,730 & 1,703 & 1,676 & 1,648 & 1,620 & 1,592 & 1,564 & 1,536 & 1,508 & 1,480 & 1,452 & 1,424 \\
\hline
\end{tabular}

Note: The tables report the results from the extended Growth-at-Risk specification described in equation (10). By standardizing covariates before estimation, the coefficient in the "Average Leverage" scenario corresponds to the estimate $\hat{\beta}_{\tau}^{h}$. This indicates the impact of CRE price misalignment on GDP growth-at-risk when the level of Credit-to-GDP gap is at its historical average. The coefficient reported in the "High Leverage" scenario corresponds to the sum of the estimated coefficients $\hat{\beta}_{\tau}^{h}$ and $\hat{\lambda}_{\tau}^{h}$ in equation 10 . The estimated sum of $\hat{\beta}_{\tau}^{h}$ and $\hat{\lambda}_{\tau}^{h}$ refers to the impact of CRE price misalignment when Credit-to-GDP gap is one standard deviation higher than its historical average. The models are estimated using the full sample of core economies. The dependent variable corresponds to the $5^{\text {th }}$ percentile of the average GDP growth distribution over the forecasting horizon h. Standard errors are bootstrapped and shown in parentheses. ${ }^{* * *} \mathrm{p}<0.01,{ }^{* *} \mathrm{p}<0.05,{ }^{*} \mathrm{p}<0.1$. 
Table 6. Amplification effect of CRE Price Misalignment on Growth-at-Risk through Cross-Border Capital Flows-to-GDP Gap

\begin{tabular}{|c|c|c|c|c|c|c|c|c|c|c|c|c|c|c|c|c|}
\hline $\begin{array}{l}\text { Scenario with Average Cross- } \\
\text { Border Investments }\end{array}$ & $h=1$ & $h=2$ & $h=3$ & $\mathrm{~h}=4$ & $h=5$ & $h=6$ & $h=7$ & $h=8$ & $h=9$ & $h=10$ & $h=11$ & $h=12$ & $h=13$ & $\mathrm{~h}=14$ & $h=15$ & $\mathrm{~h}=16$ \\
\hline $\begin{array}{l}\text { Effect of CRE price misalignment } \\
\text { with average cross-border CRE } \\
\text { capital-flows-to-GDP gap } \\
\left(\hat{\beta}_{\tau}^{h}\right)\end{array}$ & $\begin{array}{l}0.029 \\
(0.135) \\
\end{array}$ & $\begin{array}{l}-0.069 \\
(0.143) \\
\end{array}$ & $\begin{array}{l}0.206 \\
(0.156)\end{array}$ & $\begin{array}{l}0.241^{* * *} \\
(0.079)\end{array}$ & $\begin{array}{l}0.211^{* *} \\
(0.105)\end{array}$ & $\begin{array}{l}0.201^{* *} \\
(0.055)\end{array}$ & $\begin{array}{l}0.095^{* *} \\
(0.044)\end{array}$ & $\begin{array}{l}0.088^{\star *} \\
(0.040)\end{array}$ & $\begin{array}{l}0.098^{* *} \\
(0.031)\end{array}$ & $\begin{array}{l}0.016 \\
(0.033)\end{array}$ & $\begin{array}{l}0.034 \\
(0.039)\end{array}$ & $\begin{array}{l}0.060^{* *} \\
(0.031)\end{array}$ & $\begin{array}{l}0.025 \\
(0.045)\end{array}$ & $\begin{array}{l}0.005 \\
(0.055)\end{array}$ & $\begin{array}{l}0.013 \\
(0.030)\end{array}$ & $\begin{array}{l}0.023 \\
(0.031)\end{array}$ \\
\hline $\begin{array}{l}\text { Scenario with High Cross-Border } \\
\text { Investments }\end{array}$ & $h=1$ & $h=2$ & $h=3$ & $h=4$ & $h=5$ & $h=6$ & $h=7$ & $h=8$ & $h=9$ & $h=10$ & $h=11$ & $h=12$ & $h=13$ & $\mathrm{~h}=14$ & $h=15$ & $\mathrm{~h}=16$ \\
\hline $\begin{array}{l}\text { Effect of CRE price misalignment } \\
\text { with high cross-border CRE capital- } \\
\text { flows-to-GDP gap } \\
\left(\hat{\beta}_{\tau}^{h}+\hat{\lambda}_{\tau}^{h}\right)\end{array}$ & $\begin{array}{l}-0.452^{* *} \\
(0.186)\end{array}$ & $\begin{array}{l}-0.545^{* * *} \\
(0.0904)\end{array}$ & $\begin{array}{l}-0.325^{\star * \star} \\
(0.0986)\end{array}$ & $\begin{array}{l}-0.322^{* \star *} \\
(0.0766)\end{array}$ & $\begin{array}{l}-0.323^{* * *} \\
(0.0835)\end{array}$ & $\begin{array}{l}-0.367^{\star \star \star} \\
(0.102)\end{array}$ & $\begin{array}{l}-0.398^{\star * \star} \\
(0.0901)\end{array}$ & $\begin{array}{l}-0.376^{* \star *} \\
(0.0704)\end{array}$ & $\begin{array}{l}-0.338^{\star * \star} \\
(0.0416)\end{array}$ & $\begin{array}{l}-0.345^{* * *} \\
(0.0299)\end{array}$ & $\begin{array}{l}-0.307^{\star \star \star} \\
(0.0588)\end{array}$ & $\begin{array}{l}-0.334^{* * *} \\
(0.0373)\end{array}$ & $\begin{array}{l}-0.325^{* * *} \\
(0.0695)\end{array}$ & $\begin{array}{l}-0.289^{* * *} \\
(0.0592)\end{array}$ & $\begin{array}{l}-0.285^{* * *} \\
(0.0387)\end{array}$ & $\begin{array}{l}-0.275^{* \star \star} \\
(0.0389)\end{array}$ \\
\hline $\begin{array}{l}\text { Country FE } \\
\text { CRE price growth lag } \\
\text { Macro Controls } \\
\text { Observations } \\
\end{array}$ & $\begin{array}{l}\text { YES } \\
\text { YES } \\
\text { YES } \\
1,792 \\
\end{array}$ & $\begin{array}{c}\text { YES } \\
\text { YES } \\
\text { YES } \\
1,792 \\
\end{array}$ & $\begin{array}{c}\text { YES } \\
\text { YES } \\
\text { YES } \\
1,785 \\
\end{array}$ & $\begin{array}{l}\text { YES } \\
\text { YES } \\
\text { YES } \\
1,757 \\
\end{array}$ & $\begin{array}{c}\text { YES } \\
\text { YES } \\
\text { YES } \\
1,730 \\
\end{array}$ & $\begin{array}{c}\text { YES } \\
\text { YES } \\
\text { YES } \\
1,703 \\
\end{array}$ & $\begin{array}{l}\text { YES } \\
\text { YES } \\
\text { YES } \\
1,676 \\
\end{array}$ & $\begin{array}{c}\text { YES } \\
\text { YES } \\
\text { YES } \\
1,648 \\
\end{array}$ & $\begin{array}{c}\text { YES } \\
\text { YES } \\
\text { YES } \\
1,620 \\
\end{array}$ & $\begin{array}{c}\text { YES } \\
\text { YES } \\
\text { YES } \\
1,592 \\
\end{array}$ & $\begin{array}{c}\text { YES } \\
\text { YES } \\
\text { YES } \\
1,564 \\
\end{array}$ & $\begin{array}{l}\text { YES } \\
\text { YES } \\
\text { YES } \\
1,536 \\
\end{array}$ & $\begin{array}{c}\text { YES } \\
\text { YES } \\
\text { YES } \\
1,508 \\
\end{array}$ & $\begin{array}{c}\text { YES } \\
\text { YES } \\
\text { YES } \\
1,480 \\
\end{array}$ & $\begin{array}{c}\text { YES } \\
\text { YES } \\
\text { YES } \\
1,452 \\
\end{array}$ & $\begin{array}{l}\text { YES } \\
\text { YES } \\
\text { YES } \\
1,424 \\
\end{array}$ \\
\hline
\end{tabular}

Note: The tables report the results from the extended Growth-at-Risk specification described in equation (10). By standardizing covariates before estimation, the coefficient in the "Average Cross-Border Investments" scenario corresponds to the estimate $\hat{\beta}_{\tau}^{h}$. This indicates the impact of CRE price misalignment on GDP growth-at-risk when the level of cross-border CRE capital-flows-to-GDP gap is at its historical average. The coefficient reported in the "High Cross-Border Investments" scenario corresponds to the sum of the estimated coefficients $\hat{\beta}_{\tau}^{h}$ and $\hat{\lambda}_{\tau}^{h}$ in equation 10 . The estimated sum of $\hat{\beta}_{\tau}^{h}$ and $\hat{\lambda}_{\tau}^{h}$ refers to the impact of CRE price misalignment when cross-border CRE capital-flows-to-GDP gap is one standard deviation higher than its historical average. The models are estimated using the full sample of core economies. The dependent variable corresponds to the $5^{\text {th }}$ percentile of the average GDP growth distribution over the forecasting horizon h. Standard errors are bootstrapped and shown in parentheses. $* * * \mathrm{p}<0.01, * * \mathrm{p}<0.05, * \mathrm{p}<0.1$ 
Table 7. Impact of CRE-Specific Macroprudential Policy Measures on CRE Prices-at-Risk

\begin{tabular}{|c|c|c|c|c|c|c|c|c|c|c|c|c|c|c|c|c|}
\hline VARIABLES & $h=1$ & $h=2$ & $h=3$ & $h=4$ & $h=5$ & $h=6$ & $h=7$ & $h=8$ & $h=9$ & $h=10$ & $h=11$ & $h=12$ & $h=13$ & $h=14$ & $h=15$ & $\mathrm{~h}=16$ \\
\hline \multirow[t]{2}{*}{ GDP growth (-1) } & 0.107 & 0.223 & -0.208 & -0.098 & 0.025 & 0.123 & 0.097 & 0.123 & 0.075 & 0.126 & 0.188 & 0.095 & 0.054 & 0.082 & 0.048 & 0.118 \\
\hline & $(0.239)$ & $(0.442)$ & $(0.526)$ & $(0.421)$ & $(0.337)$ & $(0.365)$ & $(0.317)$ & $(0.274)$ & $(0.179)$ & $(0.264)$ & $(0.234)$ & $(0.208)$ & $(0.178)$ & $(0.280)$ & $(0.114)$ & $(0.114)$ \\
\hline \multirow[t]{2}{*}{ Financial conditions index (-1) } & -0.396 & $-0.647^{\star *}$ & $-0.586^{* *}$ & $-0.565^{*}$ & $-0.586^{\star *}$ & $-0.621^{* * *}$ & $-0.482^{* *}$ & $-0.345^{\star \star}$ & -0.237 & -0.194 & -0.130 & -0.198 & -0.092 & -0.008 & -0.037 & 0.043 \\
\hline & $(0.378)$ & $(0.271)$ & $(0.239)$ & $(0.298)$ & $(0.271)$ & $(0.195)$ & $(0.188)$ & $(0.175)$ & $(0.169)$ & $(0.226)$ & $(0.244)$ & $(0.239)$ & $(0.253)$ & $(0.230)$ & $(0.208)$ & $(0.145)$ \\
\hline \multirow[t]{2}{*}{ Capital Inflow-to-GDP (-1) } & $-1.074^{\star \star *}$ & $-1.414^{* \star *}$ & $-1.323^{\star \star \star}$ & $-1.394^{* * *}$ & $-1.545^{\star \star *}$ & $-1.378^{* \star *}$ & $-1.224^{\star \star *}$ & $-0.973^{* \star *}$ & $-0.788^{\star \star \star}$ & $-0.599^{* \star *}$ & $-0.566^{*}$ & -0.449 & $-0.431^{\star * \star}$ & $-0.511^{\star \star *}$ & $-0.333^{* \star \star}$ & $-0.279^{\star * *}$ \\
\hline & $(0.303)$ & $(0.342)$ & $(0.329)$ & $(0.282)$ & $(0.441)$ & $(0.348)$ & $(0.237)$ & $(0.148)$ & $(0.209)$ & $(0.217)$ & $(0.290)$ & $(0.316)$ & $(0.144)$ & $(0.162)$ & $(0.102)$ & $(0.106)$ \\
\hline \multirow[t]{2}{*}{ Change in Credit-to-GDP (-1) } & $-0.647^{\star \star \star}$ & -0.185 & -0.171 & -0.099 & -0.179 & -0.199 & -0.111 & -0.048 & -0.041 & -0.068 & -0.132 & -0.242 & -0.221 & -0.187 & -0.130 & -0.198 \\
\hline & $(0.217)$ & $(0.226)$ & $(0.317)$ & $(0.269)$ & $(0.302)$ & $(0.344)$ & $(0.284)$ & $(0.291)$ & $(0.319)$ & $(0.343)$ & $(0.377)$ & $(0.326)$ & $(0.293)$ & $(0.238)$ & $(0.186)$ & $(0.173)$ \\
\hline \multirow[t]{2}{*}{$\operatorname{VIX}(-1)$} & $-0.744^{* *}$ & $-0.775^{\star \star *}$ & $-0.683^{* *}$ & $-0.614^{*}$ & -0.495 & $-0.318^{\star \star}$ & -0.292 & -0.200 & -0.156 & 0.055 & 0.087 & 0.082 & 0.003 & 0.195 & 0.158 & 0.081 \\
\hline & $(0.364)$ & $(0.286)$ & $(0.312)$ & $(0.358)$ & $(0.304)$ & $(0.153)$ & $(0.224)$ & $(0.237)$ & $(0.310)$ & $(0.321)$ & $(0.299)$ & $(0.272)$ & $(0.182)$ & $(0.208)$ & $(0.138)$ & $(0.117)$ \\
\hline \multirow[t]{2}{*}{ Monetary policy shock } & 0.095 & -0.026 & -0.014 & 0.061 & 0.217 & 0.268 & 0.227 & 0.144 & 0.067 & -0.112 & -0.178 & -0.231 & -0.213 & -0.089 & -0.124 & -0.065 \\
\hline & $(0.230)$ & $(0.205)$ & $(0.192)$ & $(0.235)$ & $(0.148)$ & $(0.213)$ & $(0.182)$ & $(0.209)$ & $(0.240)$ & $(0.233)$ & $(0.225)$ & $(0.183)$ & $(0.170)$ & $(0.125)$ & $(0.133)$ & $(0.127)$ \\
\hline \multirow[t]{2}{*}{$\begin{array}{l}\text { CRE-specific macroprudential } \\
\text { measure }\end{array}$} & 0.086 & $0.156^{\star \star \star}$ & $0.165^{\star \star}$ & $0.202^{* \star *}$ & $0.244^{\star \star *}$ & $0.282^{* \star \star}$ & $0.307^{\star \star \star}$ & $0.326^{\star \star *}$ & $0.201^{* *}$ & 0.125 & -0.025 & -0.066 & -0.073 & -0.024 & 0.006 & 0.037 \\
\hline & $(0.069)$ & $(0.052)$ & $(0.081)$ & $(0.054)$ & $(0.054)$ & $(0.055)$ & $(0.064)$ & $(0.085)$ & $(0.080)$ & $(0.134)$ & $(0.160)$ & $(0.158)$ & $(0.137)$ & $(0.138)$ & $(0.075)$ & $(0.064)$ \\
\hline \multirow[t]{2}{*}{ CRE price misalignment } & $-0.923^{\star \star *}$ & $-1.204^{* * *}$ & $-1.315^{* \star *}$ & $-1.261^{* * *}$ & $-1.263^{* \star *}$ & $-1.265^{* * *}$ & $-1.178^{* \star *}$ & $-1.185^{* * *}$ & $-1.099^{* * *}$ & $-1.080^{* * \star}$ & $-1.047^{* * *}$ & $-0.992^{* * \star}$ & $-0.931^{* * *}$ & $-0.881^{* * *}$ & $-0.862^{\star \star \star}$ & $-0.912^{* \star \star}$ \\
\hline & $(0.203)$ & $(0.246)$ & $(0.295)$ & $(0.215)$ & $(0.237)$ & $(0.184)$ & $(0.146)$ & $(0.119)$ & $(0.151)$ & $(0.206)$ & $(0.167)$ & $(0.197)$ & $(0.143)$ & $(0.121)$ & $(0.081)$ & $(0.076)$ \\
\hline Country FE & YES & YES & YES & YES & YES & YES & YES & YES & YES & YES & YES & YES & YES & YES & YES & YES \\
\hline CRE prices growth lag & YES & YES & YES & YES & YES & YES & YES & YES & YES & YES & YES & YES & YES & YES & YES & YES \\
\hline Observations & 693 & 685 & 675 & 664 & 653 & 642 & 631 & 620 & 609 & 598 & 587 & 576 & 565 & 554 & 543 & 532 \\
\hline
\end{tabular}

Note: The tables report the estimated coefficients from the extended CRE Price-at-Risk specification described in equation (11). The models are estimated using the full sample of core economies. The dependent variable corresponds to the $5^{\text {th }}$ percentile of the average CRE prices growth distribution over the forecasting horizon $\mathrm{h}$. CRE-specific measures are defined as a categorical variable taking values -1 , 0 , or 1 if there was a loosening action, no change, or a tightening action, respectively, in a quarter. These include borrower-based policies that limit borrowers' access to bank credit, such as CRE-specific loan0 , or 1 if there was a loosening action, no change, or a tightening action, respectively, in a quarter. These include borrower-based policies that limit borrowers' access to bank credit, such as CRE-specific loan-
to-value (LTV) and debt service-to-income (DSTI) ratios, and capital-based policies that enhance banks' resilience, such as higher risk weights and sectoral capital buffers for CRE exposures. The policy measures are purged of credit-to-GDP ratio to address potential endogeneity. The monetary policy shock is measured by the predicted residual from regressing the policy rate on contemporaneous and lagged variables and a quadratic time trend as in Iacoviello and Navarro (2019). All covariates are standardized so that magnitudes of coefficients indicate relative importance of variables. Standard errors are bootstrapped and shown in parentheses. ${ }^{* * *} \mathrm{p}<0.01,{ }^{* *} \mathrm{p}<0.05,{ }^{*} \mathrm{p}<0.1$. 
Table 8. Impact of CRE-Specific Capital- and Borrower-Based Measures on CRE Prices-at-Risk

\begin{tabular}{|c|c|c|c|c|c|c|c|c|c|c|c|c|c|c|c|c|}
\hline VARIABLES & $h=1$ & $h=2$ & $h=3$ & $h=4$ & $\mathrm{~h}=5$ & $\mathrm{~h}=6$ & $h=7$ & $h=8$ & $h=9$ & $h=10$ & $h=11$ & $h=12$ & $h=13$ & $h=14$ & $h=15$ & $h=16$ \\
\hline \multirow[t]{2}{*}{ GDP growth (-1) } & 0.099 & 0.218 & -0.196 & 0.002 & 0.043 & 0.145 & 0.108 & 0.120 & 0.069 & 0.209 & 0.310 & 0.079 & 0.136 & 0.050 & 0.089 & 0.086 \\
\hline & $(0.162)$ & $(0.464)$ & $(0.410)$ & $(0.422)$ & $(0.341)$ & $(0.302)$ & $(0.278)$ & $(0.202)$ & $(0.293)$ & $(0.193)$ & $(0.224)$ & $(0.279)$ & $(0.174)$ & $(0.235)$ & $(0.159)$ & $(0.116)$ \\
\hline \multirow[t]{2}{*}{ Financial conditions index (-1) } & $-0.351^{*}$ & $-0.679^{\star *}$ & $-0.612^{* *}$ & -0.546 & $-0.528^{\star \star}$ & $-0.579^{* \star}$ & $-0.404^{\star \star}$ & -0.338 & -0.252 & -0.129 & 0.044 & -0.066 & -0.016 & -0.025 & 0.024 & 0.068 \\
\hline & $(0.200)$ & $(0.298)$ & $(0.257)$ & $(0.347)$ & $(0.239)$ & $(0.243)$ & $(0.158)$ & $(0.211)$ & $(0.164)$ & $(0.239)$ & $(0.218)$ & $(0.244)$ & $(0.160)$ & $(0.210)$ & $(0.155)$ & $(0.116)$ \\
\hline \multirow[t]{2}{*}{ Capital inflow-to-GDP (-1) } & $-1.190^{* * *}$ & $-1.415^{\star \star \star}$ & $-1.312^{* \star *}$ & $-1.459^{\star \star \star}$ & $-1.537^{\star \star *}$ & $-1.360^{\star \star \star}$ & $-1.152^{\star \star \star}$ & $-0.973^{\star \star \star}$ & $-0.753^{* * *}$ & $-0.648^{* * *}$ & $-0.562^{* * *}$ & $-0.508^{\star \star \star}$ & $-0.463^{* *}$ & $-0.456^{\star \star \star}$ & $-0.355^{\star * *}$ & $-0.237^{\star}$ \\
\hline & $(0.236)$ & $(0.374)$ & $(0.198)$ & $(0.375)$ & $(0.465)$ & $(0.256)$ & $(0.227)$ & $(0.186)$ & $(0.147)$ & $(0.149)$ & $(0.158)$ & $(0.184)$ & $(0.196)$ & $(0.107)$ & $(0.122)$ & $(0.135)$ \\
\hline \multirow[t]{2}{*}{ Change in Credit-to-GDP (-1) } & $-0.608^{\star * *}$ & -0.175 & -0.116 & -0.098 & -0.226 & -0.215 & 0.006 & -0.057 & 0.014 & -0.015 & 0.029 & -0.267 & -0.156 & -0.165 & -0.138 & -0.230 \\
\hline & $(0.174)$ & $(0.213)$ & $(0.221)$ & $(0.282)$ & $(0.291)$ & $(0.368)$ & $(0.361)$ & $(0.292)$ & $(0.311)$ & $(0.300)$ & $(0.276)$ & $(0.320)$ & $(0.283)$ & $(0.286)$ & $(0.250)$ & $(0.193)$ \\
\hline \multirow[t]{2}{*}{$\operatorname{VIX}(-1)$} & $-0.557^{\star}$ & $-0.753^{* \star}$ & $-0.690^{* *}$ & $-0.629^{\star \star \star}$ & -0.534 & -0.394 & -0.245 & -0.210 & -0.082 & 0.041 & -0.021 & 0.057 & 0.024 & 0.130 & 0.121 & 0.062 \\
\hline & $(0.299)$ & $(0.312)$ & $(0.280)$ & $(0.238)$ & $(0.325)$ & $(0.266)$ & $(0.332)$ & $(0.246)$ & $(0.331)$ & $(0.292)$ & $(0.296)$ & $(0.173)$ & $(0.187)$ & $(0.143)$ & $(0.107)$ & $(0.098)$ \\
\hline \multirow{2}{*}{ Monetary policy shock } & 0.038 & -0.024 & 0.014 & 0.056 & 0.187 & 0.181 & 0.242 & 0.132 & 0.034 & -0.096 & -0.146 & -0.212 & $-0.240^{*}$ & -0.105 & -0.131 & -0.107 \\
\hline & $(0.196)$ & $(0.195)$ & $(0.197)$ & $(0.191)$ & $(0.164)$ & $(0.162)$ & $(0.227)$ & $(0.227)$ & $(0.215)$ & $(0.212)$ & $(0.233)$ & $(0.185)$ & $(0.137)$ & $(0.123)$ & $(0.097)$ & $(0.105)$ \\
\hline \multirow[t]{2}{*}{$\begin{array}{l}\text { CRE-specific borrower-based } \\
\text { measures }\end{array}$} & 0.001 & -0.003 & 0.082 & 0.109 & $0.222^{\star}$ & $0.194^{*}$ & $0.282^{* *}$ & $0.332^{\star \star \star}$ & $0.195^{*}$ & 0.213 & 0.191 & 0.204 & 0.080 & 0.081 & 0.065 & 0.040 \\
\hline & $(0.105)$ & $(0.101)$ & $(0.118)$ & $(0.138)$ & -0.135 & -0.09 & -0.103 & $(0.109)$ & $(0.095$ & -0.13 & $(0.138)$ & $(0.183)$ & $(0.166)$ & $(0.140)$ & $(0.095)$ & $(0.094)$ \\
\hline \multirow{2}{*}{$\begin{array}{l}\text { CRE-specific capital-based } \\
\text { measures }\end{array}$} & -0.042 & 0.019 & 0.050 & 0.161 & 0.070 & 0.134 & 0.139 & 0.144 & $0.321^{* *}$ & $0.311^{*}$ & $0.379^{* * *}$ & $0.341^{* \star *}$ & $0.342^{* \star *}$ & $0.354^{\star \star \star}$ & $0.288^{\star \star \star}$ & $0.244^{\star \star \star}$ \\
\hline & $(0.111)$ & $(0.141)$ & $(0.164)$ & $(0.151)$ & $(0.145)$ & $(0.148)$ & $(0.214)$ & $(0.152)$ & $(0.127)$ & $(0.173)$ & $(0.131)$ & $(0.114)$ & $(0.107)$ & $(0.087)$ & $(0.099)$ & $(0.086)$ \\
\hline \multirow[t]{2}{*}{ CRE price misalignment } & $-0.882^{* \star *}$ & $-1.211^{* \star *}$ & $-1.294^{* \star *}$ & $-1.278^{\star \star \star}$ & $-1.237^{\star \star \star}$ & $-1.272^{* \star \star}$ & $-1.233^{\star \star \star}$ & $-1.184^{* \star *}$ & $-1.082^{* \star *}$ & $-1.088^{* \star *}$ & $-1.075^{* \star *}$ & $-0.900^{* \star *}$ & $-0.957^{\star \star \star}$ & $-0.873^{* \star *}$ & $-0.873^{\star * *}$ & $-0.899^{* * *}$ \\
\hline & $(0.182)$ & $(0.244)$ & $(0.252)$ & $(0.270)$ & $(0.222)$ & $(0.242)$ & $(0.140)$ & $(0.179)$ & $(0.135)$ & $(0.174)$ & $(0.175)$ & $(0.122)$ & $(0.137)$ & $(0.127)$ & $(0.156)$ & $(0.072)$ \\
\hline Country FE & YES & YES & YES & YES & YES & YES & YES & YES & YES & YES & YES & YES & YES & YES & YES & YES \\
\hline CRE prices growth lag & YES & YES & YES & YES & YES & YES & YES & YES & YES & YES & YES & YES & YES & YES & YES & YES \\
\hline Observations & 693 & 685 & 675 & 664 & 653 & 642 & 631 & 620 & 609 & 598 & 587 & 576 & 565 & 554 & 543 & 532 \\
\hline
\end{tabular}

Note: The tables report the estimated coefficients from the extended CRE Price-at-Risk specification described in equation (11) where the categorical variable identifying CRE-specific measures is replaced with two categorical variables identifying CRE-specific borrower-based and capital-based measures targeting both CRE markets. The models are estimated using the full sample of core economies. The dependent variable corresponds to the $5^{\text {th }}$ percentile of the average CRE prices growth distribution over the forecasting horizon $\mathrm{h}$. The policy measures are defined as a categorical variable taking values $-1,0$, or 1 if there was a loosening action, no change, or a tightening action, respectively, in a quarter and are purged of credit-to-GDP ratio to address potential endogeneity concerns. CREspecific borrower-based policies include limit borrowers' access to bank credit, such as CRE-specific loan-to-value (LTV) and debt service-to-income (DSTI) ratios. CRE-specific capital-based policies include measures to enhance banks' resilience, such as higher risk weights and sectoral capital buffers for CRE exposures. The monetary policy shock is measured by the predicted residual from regressing the policy rate on contemporaneous and lagged variables and a quadratic time trend as in Iacoviello and Navarro (2019). All covariates are standardized so that magnitudes of coefficients indicate relative importance of variables. Standard errors are bootstrapped and shown in parentheses. ${ }^{* * *} \mathrm{p}<0.01,{ }^{* *} \mathrm{p}<0.05,{ }^{*} \mathrm{p}<0.1$. 
Table 9. Effect of CRE-Specific Macroprudential Policy Measures on CRE Prices-at-Risk through CRE Price Misalignment

\begin{tabular}{|c|c|c|c|c|c|c|c|c|c|c|c|c|c|c|c|c|}
\hline $\begin{array}{l}\text { Scenario with Low CRE price } \\
\text { Misalignment }\end{array}$ & $h=1$ & $h=2$ & $h=3$ & $h=4$ & $h=5$ & $\mathrm{~h}=6$ & $h=7$ & $h=8$ & $h=9$ & $h=10$ & $h=11$ & $h=12$ & $h=13$ & $h=14$ & $h=15$ & $h=16$ \\
\hline \multicolumn{17}{|l|}{$\begin{array}{l}\text { Effect of CRE-Specific } \\
\text { Macroprudential }\end{array}$} \\
\hline \multirow{2}{*}{$\begin{array}{l}\text { Measures with Low CRE Price } \\
\text { Misalignment } \\
\left(\hat{\phi}_{\tau}^{h}\right)\end{array}$} & 0.088 & $0.239^{\star \star \star}$ & $0.245^{\star \star \star}$ & $0.258^{\star \star \star}$ & $0.260^{\star \star *}$ & $0.284^{* \star *}$ & $0.307^{\star \star \star}$ & $0.315^{\star \star \star}$ & $0.245^{* \star *}$ & $0.229^{* \star *}$ & $0.185^{\star \star \star}$ & $0.160^{*}$ & $0.154^{* *}$ & $0.149^{* *}$ & $0.139^{\star \star \star}$ & $0.120^{\star \star \star}$ \\
\hline & $(0.080)$ & $(0.075)$ & $(0.066)$ & $(0.079)$ & $(0.054)$ & $(0.064)$ & $(0.033)$ & $(0.059)$ & $(0.071)$ & $(0.073)$ & $(0.038)$ & $(0.083)$ & $(0.067)$ & $(0.064)$ & $(0.053)$ & $(0.035)$ \\
\hline $\begin{array}{l}\text { Scenario with High CRE-Price } \\
\text { Misalignment }\end{array}$ & $h=1$ & $\mathrm{~h}=2$ & $h=3$ & $h=4$ & $h=5$ & $h=6$ & $h=7$ & $h=8$ & $h=9$ & $h=10$ & $h=11$ & $\mathrm{~h}=12$ & $h=13$ & $h=14$ & $h=15$ & $h=16$ \\
\hline \multirow{3}{*}{$\begin{array}{l}\text { Effect of CRE-Specific } \\
\text { Macroprudential } \\
\text { Measures with High CRE Price } \\
\text { Misalignment } \\
\left(\hat{\phi}_{\tau}^{h}+\widehat{\sigma}_{\tau}^{h}\right)\end{array}$} & & & & & & & & & & & & & & & & \\
\hline & 0.328 & $0.483^{* *}$ & $0.471^{* *}$ & $0.439^{* * *}$ & $0.358^{* * *}$ & $0.275^{\star * *}$ & $0.314^{\star \star *}$ & $0.289^{\star \star *}$ & 0.114 & 0.0531 & -0.00631 & -0.0512 & -0.0531 & -0.0227 & 0.0114 & 0.0407 \\
\hline & $(0.274)$ & $(0.201)$ & $(0.214)$ & $(0.150)$ & $(0.139)$ & $(0.100)$ & $(0.066)$ & $(0.074)$ & $(0.116)$ & $(0.116)$ & $(0.059)$ & $(0.182)$ & $(0.150)$ & $(0.131)$ & $(0.128)$ & $(0.048)$ \\
\hline Country FE & YES & YES & YES & YES & YES & YES & YES & YES & YES & YES & YES & YES & YES & YES & YES & YES \\
\hline CRE price growth lag & YES & YES & YES & YES & YES & YES & YES & YES & YES & YES & YES & YES & YES & YES & YES & YES \\
\hline Macro Controls & YES & YES & YES & YES & YES & YES & YES & YES & YES & YES & YES & YES & YES & YES & YES & YES \\
\hline Observations & 693 & 685 & 675 & 664 & 653 & 642 & 631 & 620 & 609 & 598 & 587 & 576 & 565 & 554 & 543 & 532 \\
\hline
\end{tabular}

Note: The tables report the estimated coefficients from the extended CRE Price-at-Risk specification described in equation (12). The models are estimated using a sub-sample of economies where at least one CRE-specific measure has been announced in the sample period. By standardizing covariates before estimation, the coefficient in the "Low CRE Price Misalignment" scenario corresponds to the estimated coefficient $\hat{\phi}_{\tau}^{h}$. This indicates the impact of CRE-specific macroprudential measure on CRE price-at-risk when the level of CRE price misalignment is close to zero. The coefficient reported in the "High CRE Price Misalignment" scenario corresponds to the sum of the estimated coefficients $\hat{\beta}_{\tau}^{h}$ and $\hat{\lambda}_{\tau}^{h}$ in equation 12. The estimated sum of $\hat{\beta}_{\tau}^{h}$ and $\hat{\lambda}_{\tau}^{h}$ refers to the impact of CRE-specific macroprudential measures when CRE price misalignment is one standard deviation higher than the level in the previous scenario. The dependent variable corresponds to the $5^{\text {th }}$ percentile of the average CRE prices growth distribution over the forecasting horizon $\mathrm{h}$. CRE-specific measures are defined as a categorical variable taking values $-1,0$, or 1 if there was a loosening action, no change, or a tightening action, respectively, in a quarter. These include borrower-based policies that limit borrowers' access to bank credit, such as CRE-specific loan-to-value (LTV) and debt service-to-income (DSTI) ratios, and capital-based policies that enhance banks' resilience, such as higher risk weights and sectoral capital buffers for CRE exposures. The policy measure is purged of credit-to-GDP ratio to address potential endogeneity. All covariates are standardized so that magnitudes of coefficients indicate relative importance of variables. Standard errors are bootstrapped and shown in parentheses. $* * *$ p $<0.01$, $* * \mathrm{p}<0.05, * \mathrm{p}<0.1$. 


\section{ANNEXes}

\section{Annex 1. Data Description and Sources}

\begin{tabular}{|c|c|c|}
\hline Variable & Description & Source \\
\hline Bank Stock Returns & Refinitiv Datastream's bank sector return index & Refinitiv Datastream \\
\hline Broad Money & Broad money, seasonally adjusted & IMF, World Economic Outlook \\
\hline Break Even Inflation & 10 -years break even inflation rate & Bloomberg \\
\hline & & Fernandez and others (2017); and \\
\hline Capital Flow Management & Measures that are designed to limit capital flows & $\begin{array}{l}\text { IMF's Annual Report on } \\
\text { Exchange Arrangements and }\end{array}$ \\
\hline & & $\begin{array}{ll}\text { Exchange } & \text { Restrictions } \\
\text { (AREAER) } & \end{array}$ \\
\hline Capital Inflows & Sum of portfolio investment and foreign direct investment & $\begin{array}{l}\text { IMF, Balance of Payments } \\
\text { database }\end{array}$ \\
\hline Consumer Price Index & Consumer price index, percent & IMF, World Economic Outlook \\
\hline CRE and CMSB & The percentage of CRE and CMBS loans within a financial institution's & Treng \\
\hline Delinquency Rates & loan portfolio whose payments are delinquent & 1 repp \\
\hline CRE Capitalization rate & Net Operating Income per CRE value & MSCI Real Estate \\
\hline CRE Investments & Investments in commercial real estate & Real Capital Analytics \\
\hline CRE Prices & Asset value index & MSCI Real Estate \\
\hline CRE Vacancy Rates & Total market rental value in vacant units / total market rental value & MSCI Real Estate \\
\hline Credit-to-GDP Ratio & Private-sector credit in percent of GDP & Bank for International Settlements \\
\hline Credit-to-GDP Gap & Deviation of Credit-to-GDP Ratio from the trend. & Bank for International Settlements \\
\hline Financial Condition Index & $\begin{array}{l}\text { For methodology and variables included in the FCI, refer to Annex } 3.2 \\
\text { of the October } 2017 \text { Global Financial Stability Report. Positive values } \\
\text { of the FCI indicate tighter-than-average financial conditions. }\end{array}$ & IMF staff estimates \\
\hline Gross Domestic Product & Gross domestic product (GDP) & IMF, World Economic Outlook \\
\hline Global Liquidity Indicator & $\begin{array}{l}\text { The sum of bank loans to non-banks and debt securities issuance by } \\
\text { non-banks }\end{array}$ & Bank for International Settlements \\
\hline $\begin{array}{l}\text { Long-Term Nominal Interest } \\
\text { Rate }\end{array}$ & $\begin{array}{l}\text { 10-years government bond yield (Please confirm. Just used the shared } \\
\text { dataset). }\end{array}$ & IMF, World Economic Outlook \\
\hline $\begin{array}{l}\text { Long-Term Real Interest } \\
\text { Rate }\end{array}$ & 10 -years real interest rate index & Bloomberg \\
\hline $\begin{array}{l}\text { Macroprudential Measures: } \\
\text { CRE-specific measures }\end{array}$ & $\begin{array}{l}\text { Measures that are designed to limit the build-up of vulnerabilities in } \\
\text { CRE sector }\end{array}$ & $\begin{array}{l}\text { IMF, The } \\
\text { integrated Macroprudential } \\
\text { Policy (iMaPP) database, BIS } \\
\text { Macroprudential Database, ESRB } \\
\text { Macroprudential Measures } \\
\text { Database, ESRB (2015, 2018, } \\
\text { 2019) }\end{array}$ \\
\hline $\begin{array}{l}\text { Macroprudential Measures: } \\
\text { Capital Requirements }\end{array}$ & $\begin{array}{l}\text { Capital requirements for banks, which include risk weights, systemic risk } \\
\text { buffers, and minimum capital requirements. Countercyclical capital } \\
\text { buffers and capital conservation buffers are captured in their sheets } \\
\text { respectively and thus not included here. }\end{array}$ & $\begin{array}{l}\text { IMF, The } \\
\text { integrated Macroprudential } \\
\text { Policy (iMaPP) database }\end{array}$ \\
\hline $\begin{array}{l}\text { Macroprudential Measures: } \\
\text { Limits on the Debt-Service- } \\
\text { to-Income Ratio }\end{array}$ & $\begin{array}{l}\text { Limits to the debt-service-to-income ratio and the loan-to-income ratio, } \\
\text { which restrict the size of debt services or debt relative to income. They } \\
\text { include those targeted at housing loans, consumer loans, and } \\
\text { commercial real estate loans. }\end{array}$ & $\begin{array}{l}\text { IMF, The } \\
\text { integrated Macroprudential } \\
\text { Policy (iMaPP) database }\end{array}$ \\
\hline Macroprudential Measures: & Limits to the loan-to-value ratios, including those mostly targeted at & IMF, The \\
\hline Limits on the Loan-to-Value & housing loans, but also includes those targeted at automobile loans, and & integrated Macroprudential \\
\hline Ratio & commercial real estate loans. & Policy (iMaPP) database \\
\hline Net Operating Income & Total net operating income for the period as an absolute amount & MSCI Real Estate \\
\hline Net Operating Income Yield & Total net operating income for the period in percent of CRE value & MSCI Real Estate \\
\hline $\begin{array}{l}\text { Short-Term } \quad \text { Nominal } \\
\text { Interest Rate }\end{array}$ & Short-term deposit rate & IMF, World Economic Outlook \\
\hline Policy Rate & Monetary policy rate and shadow rate by Leo Krippner(2013, 2015) & $\begin{array}{l}\text { IMF, World Economic Outlook, } \\
\text { Bank for International } \\
\text { Settlements, Leo Krippner(2013, } \\
\text { 2015) }\end{array}$ \\
\hline VIX & CBOE Volatility Index & Refinitiv Datastream \\
\hline
\end{tabular}




\section{Annex 2. Commercial Real Estate Prices and Fundamentals}

Identification of Shocks in SVAR and CRE Prices. To model the impact of shocks to fundamentals on CRE prices, the model is extended to include vacancy rate to capture the CRE market-specific demand shock that generates movements in demand for CRE that are distinct from aggregate demand. The model is thus defined as follows:

$$
y_{t}=\left(\begin{array}{c}
\text { NOIGrowt }_{t}, \text { RiskPremium }_{t}, 3 \text { MRate }_{t}, \text { OutputGap }_{t}, \text { Inflation }_{t}, \\
\text { Credit }_{\text {Output }_{t}}, \frac{\text { BroadMoney }_{t}}{\text { Output }_{t}}, \frac{\text { CapitalFlow }_{t}}{\text { Output }_{t}}, \text { VacancyRate }_{t}
\end{array}\right)^{\prime}
$$

where VacancyRate $_{t}$ is the inverse logit-transformation of the vacancy rate. In order to investigate the underlying shocks affecting the market, the contemporaneous parameters need to be identified. Once the dynamics of economic fundamentals that drive CRE prices is expressed in terms of shocks, the dynamics of CRE prices could also be expressed as a sum of those shocks and the misalignments. This allows to simulate the impact of any additional shocks on CRE prices.

Sign Identification and Priors. To identify the contemporaneous parameters, the signs of the endogenous relations are defined following Baumeister and Hamilton $(2015,2018)$ in Online Annex Table A2.1.

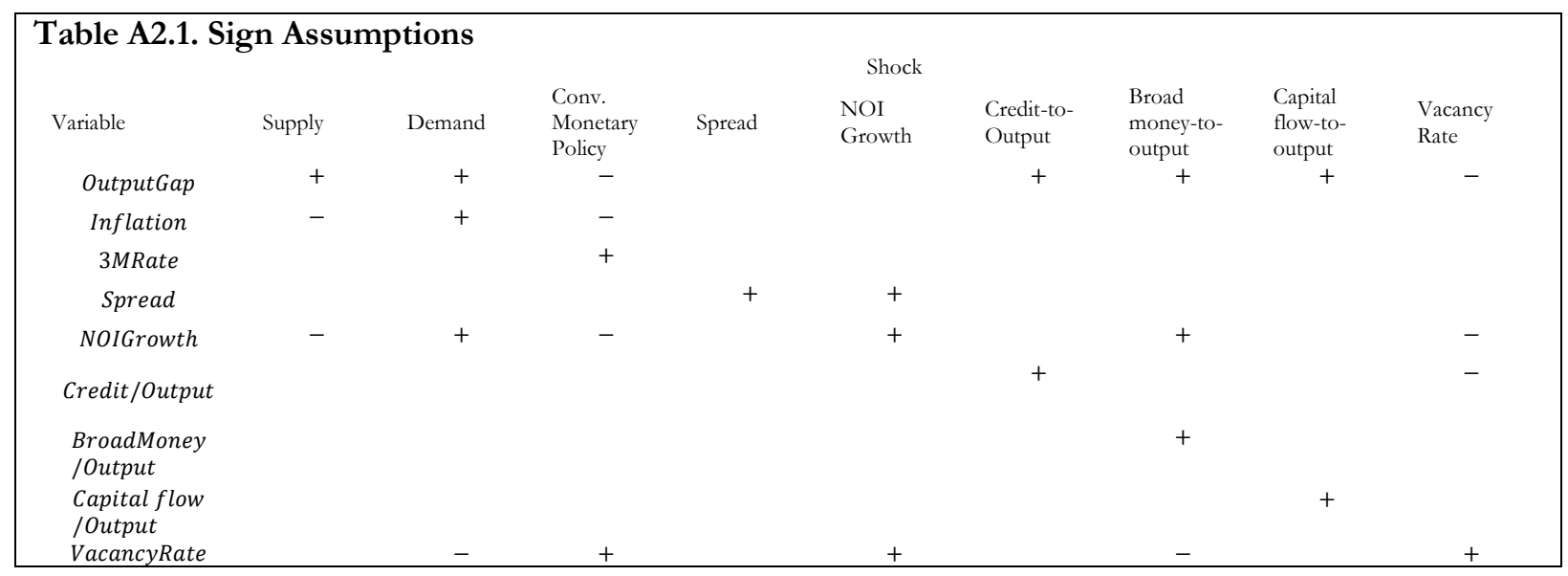

To implement this identification, prior parameter distribution and prior values are set following Baumeister and Hamilton $(2015,2018)$. Namely, the prior of the contemporaneous matrix $\mathbf{A}$ is set by truncated t-distribution to satisfy the above sign restrictions. Other prior parameters such as the magnitude of shocks (standard deviation of $\widetilde{\boldsymbol{u}}$ ) is given by the inverse Gamma distribution. The lagged structural coefficients $\widetilde{\boldsymbol{B}}(L)$ are assumed to be normal and set by Minnesota priors as outlined by Baumeister and Hamilton (2018).

Sample. The analysis in this section is performed country-by country over the period 2001:Q2 to 2019:Q4 for the following countries (unless stated otherwise): Australia, Canada, Denmark, Germany, Italy, Portugal, South Africa, Spain, Sweden, United Kingdom and United States. 
Historical Decomposition. According to equation (3), any variable in the SVAR could be written as the sum of past shocks. Ignoring the constant term, this implies the following:

$$
\widetilde{y}_{t}=\sum_{k=0}^{\infty} \mathbf{M}^{\mathrm{k}} \widetilde{\boldsymbol{u}}_{t-k}
$$

Similarly, the logarithm of the price could further be decomposed into fundamental shocks.

$$
\begin{aligned}
\log \left(\text { Price }_{t}\right)=\log \left(\text { Price }_{0}\right)+\left(\boldsymbol{d}_{\text {NoIGrowth }}-\boldsymbol{d}_{\text {RiskPremium }}-\boldsymbol{d}_{3 M \text { Rate }}\right) \rho \mathbf{M}\left(\mathbf{I}_{\mathbf{p} \times \mathbf{p}}-\rho \mathbf{M}\right)^{-1} \sum_{k=0}^{\infty} \mathbf{M}^{\mathbf{k}} \widetilde{\boldsymbol{u}}_{t-\boldsymbol{k}} \\
+\boldsymbol{d}_{\text {Inflation }} \rho^{2} \mathbf{M}^{2}\left(\mathbf{I}_{\mathbf{p} \times \mathbf{p}}-\rho \mathbf{M}\right)^{-1} \sum_{k=0}^{\infty} \mathbf{M}^{\mathrm{k}} \widetilde{\boldsymbol{u}}_{t-\boldsymbol{k}}+\boldsymbol{d}_{\text {NoIGrowth }} \sum_{s=0}^{t} \sum_{k=0}^{\infty} \mathbf{M}^{\mathrm{k}} \widetilde{\boldsymbol{u}}_{t-s-\boldsymbol{k}}+m_{t}
\end{aligned}
$$

As an example, Figure A2.1-2. depict the impulse response functions for CRE prices and risk premia using the United States. The full set of impulse response functions are available upon request.
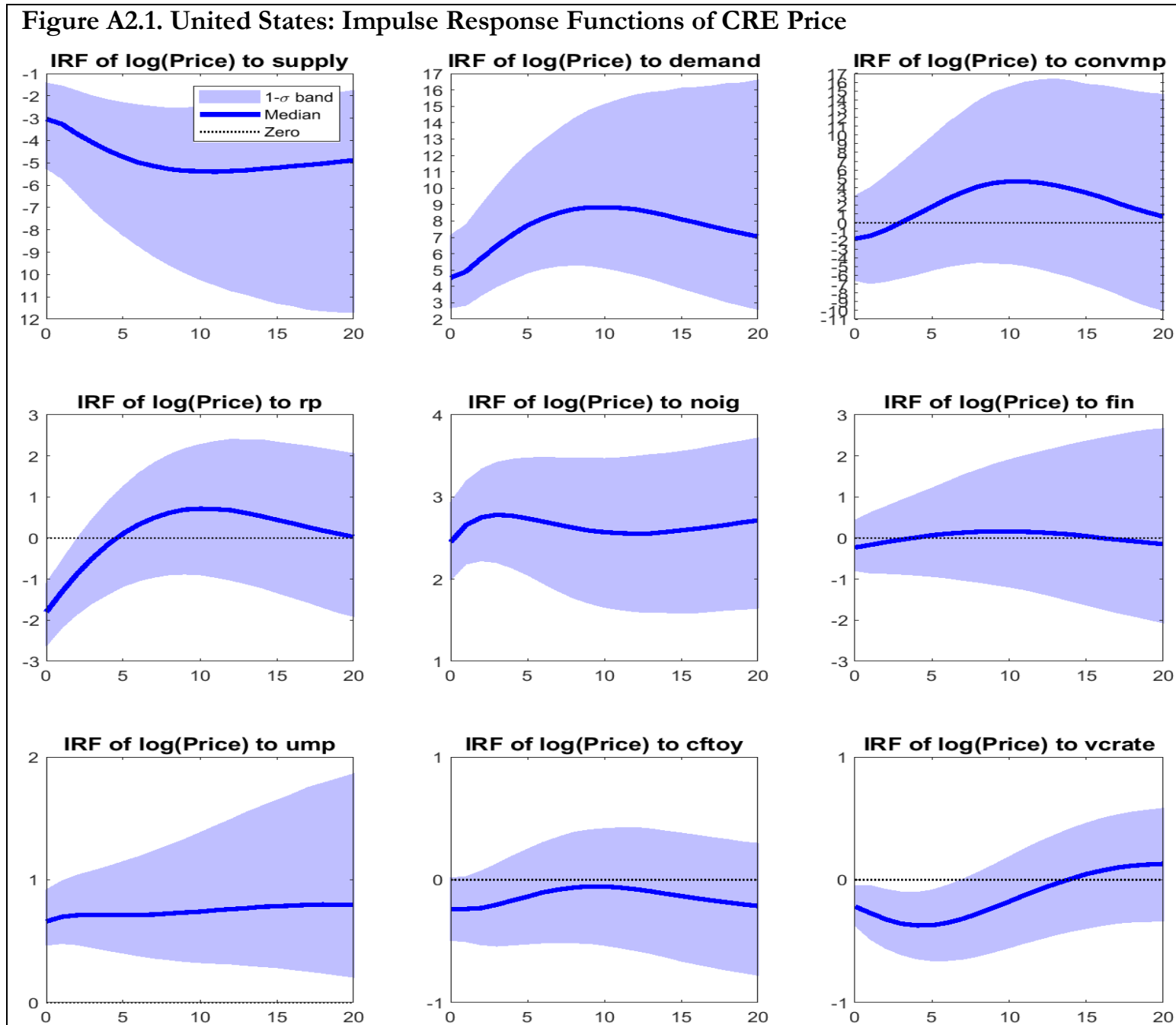

Note: The figure depicts impulse response functions of CRE prices to shocks in the CRE valuation drivers. Shaded areas corresponds to 68 percent confidence interval. The labels are defined as follows: convmp $=$ conventional monetary policy, $\mathrm{rp}=$ risk premium; $\mathrm{cftoy}=\mathrm{capital}$ flow-to-output; noig = net operating income growth; ump = unconventional monetary policy; vcrate = vacancy rate.

Figure A2.2. United States: Impulse Response Functions of Risk Premia 

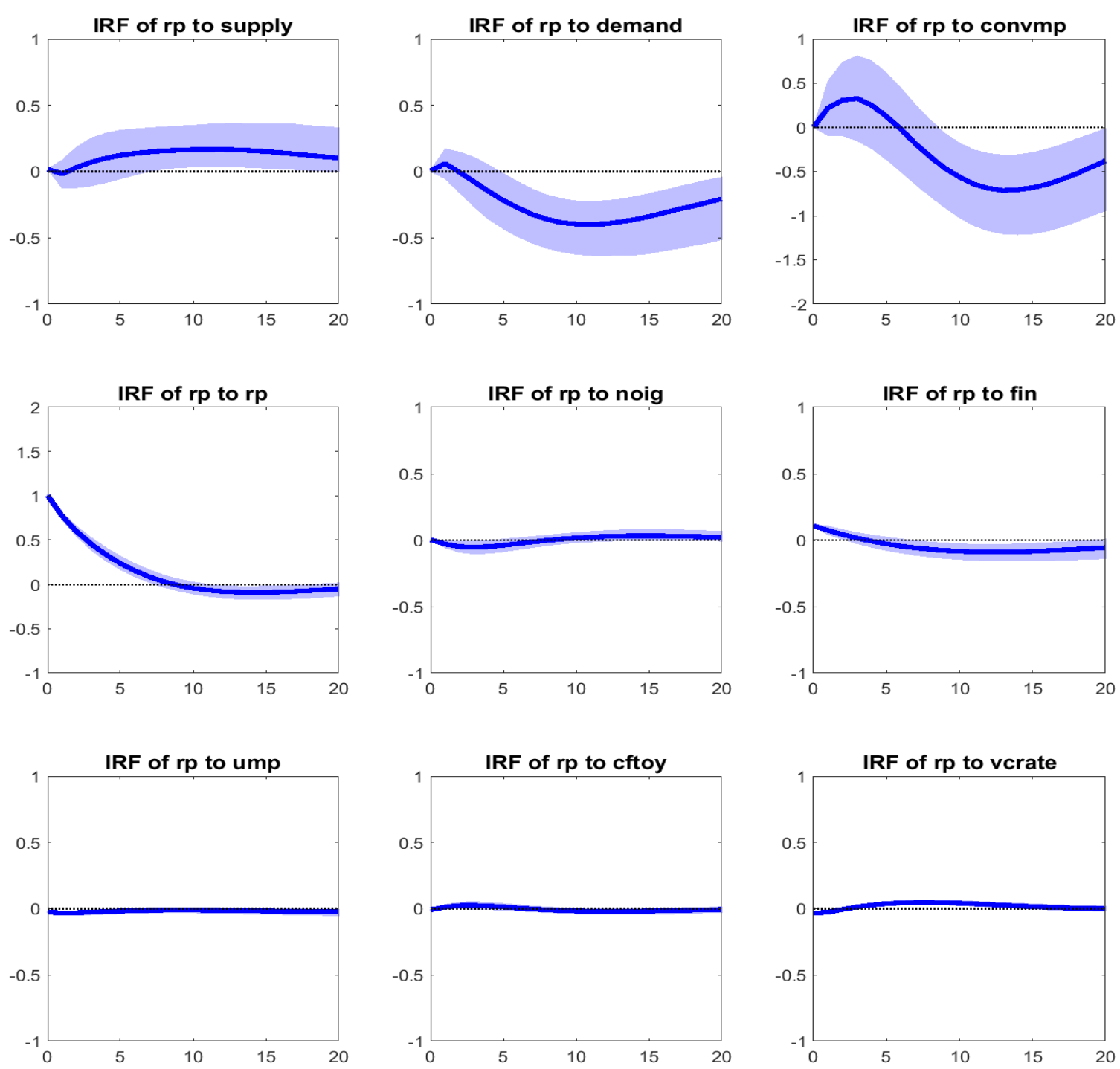

Note: The figure depicts impulse response functions of risk premia to shocks in the CRE valuation drivers. Shaded areas corresponds to 68 percent confidence interval. The labels are defined as follows: convmp $=$ conventional monetary policy, $\mathrm{rp}=$ risk premium; $\mathrm{cftoy}=\mathrm{capital}$ flow-to-output; noig = net operating income growth; $u m p=$ unconventional monetary policy; vcrate = vacancy rate. 
Annex 3. Robustness analysis

Table A3.1. CRE Prices-at-Risk Estimation Controlling for Aggregate Time Varying Effects

\begin{tabular}{|c|c|c|c|c|c|c|c|c|c|c|c|c|c|c|c|c|}
\hline VARIABLES & $h=1$ & $h=2$ & $h=3$ & $\mathrm{~h}=4$ & $h=5$ & $\mathrm{~h}=6$ & $h=7$ & $h=8$ & $h=9$ & $h=10$ & $\mathrm{~h}=11$ & $\mathrm{~h}=12$ & $\mathrm{~h}=13$ & $\mathrm{~h}=14$ & $h=15$ & $\mathrm{~h}=16$ \\
\hline \multirow[t]{2}{*}{ GDP growth } & 0.107 & 0.132 & 0.118 & 0.140 & 0.134 & 0.111 & 0.035 & 0.033 & 0.058 & 0.104 & -0.002 & -0.012 & -0.008 & -0.014 & -0.042 & -0.042 \\
\hline & $(0.109)$ & $(0.164)$ & $(0.130)$ & $(0.161)$ & $(0.104)$ & $(0.096)$ & $(0.163)$ & $(0.068)$ & $(0.071)$ & $(0.141)$ & $(0.107)$ & $(0.130)$ & $(0.093)$ & $(0.080)$ & $(0.070)$ & $(0.079)$ \\
\hline \multirow[t]{2}{*}{$\mathrm{FCl}$ conditions index } & -0.033 & -0.057 & 0.026 & -0.049 & 0.015 & 0.018 & 0.009 & 0.011 & 0.042 & 0.051 & 0.008 & 0.007 & 0.006 & 0.003 & -0.002 & 0.018 \\
\hline & $(0.083)$ & $(0.071)$ & $(0.060)$ & $(0.080)$ & $(0.060)$ & $(0.085)$ & $(0.096)$ & $(0.055)$ & $(0.065)$ & $(0.056)$ & $(0.072)$ & $(0.051)$ & $(0.065)$ & $(0.049)$ & $(0.042)$ & $(0.045)$ \\
\hline \multirow{2}{*}{ Capital Flow-to-GDP } & $-0.363^{* *}$ & $-0.481^{* \star *}$ & $-0.460^{\star \star}$ & $-0.681^{1 * \star}$ & $-0.653^{* \star *}$ & $-0.644^{* * *}$ & $-0.624^{* * *}$ & $-0.608^{* \star *}$ & $-0.505^{\star \star \star}$ & $-0.505^{\star \star *}$ & $-0.429^{\star \star * *}$ & $-0.371^{\star \star \star *}$ & $-0.377^{* * *}$ & $-0.418^{* \star *}$ & $-0.338^{* \star *}$ & $-0.287^{* \star \star}$ \\
\hline & $(0.167)$ & $(0.153)$ & $(0.191)$ & $(0.197)$ & $(0.169)$ & $(0.156)$ & $(0.164)$ & $(0.130)$ & $(0.128)$ & $(0.125)$ & $(0.090)$ & $(0.083)$ & $(0.117)$ & $(0.096)$ & $(0.053)$ & $(0.074)$ \\
\hline \multirow[t]{2}{*}{ Credit-to-GDP growth } & $-0.322^{\star \star \star}$ & $-0.342^{\star \star \star}$ & $-0.333^{\star \star}$ & -0.184 & $-0.186^{\star}$ & $-0.246^{* * *}$ & $-0.277^{\star \star}$ & $-0.293^{\star *}$ & $-0.327^{\star \star *}$ & $-0.219^{*}$ & $-0.247^{\star \star \star}$ & $-0.251^{\star *}$ & $-0.228^{* *}$ & $-0.227^{\star \star \star}$ & $-0.234^{* * *}$ & $-0.255^{\star * *}$ \\
\hline & $(0.099)$ & $(0.132)$ & $(0.139)$ & $(0.122)$ & $(0.101)$ & $(0.091)$ & $(0.113)$ & $(0.116)$ & $(0.125)$ & $(0.129)$ & $(0.092)$ & $(0.098)$ & $(0.103)$ & $(0.077)$ & $(0.076)$ & $(0.072)$ \\
\hline \multirow[t]{2}{*}{ VIX } & $-0.621^{* \star \star}$ & $-0.668^{\star \star \star}$ & $-0.691^{\star \star \star}$ & $-0.683^{* * *}$ & $-0.690^{\star \star *}$ & $-0.678^{* \star \star}$ & $-0.599^{* * *}$ & $-0.489^{* \star *}$ & $-0.349^{* \star *}$ & $-0.303^{*}$ & -0.149 & -0.052 & -0.003 & 0.025 & 0.003 & -0.010 \\
\hline & $(0.135)$ & $(0.139)$ & $(0.095)$ & $(0.194)$ & $(0.200)$ & $(0.081)$ & $(0.162)$ & $(0.124)$ & $(0.129)$ & $(0.156)$ & $(0.105)$ & $(0.125)$ & $(0.126)$ & $(0.076)$ & $(0.051)$ & $(0.052)$ \\
\hline \multirow[t]{2}{*}{ CRE price misalignment } & $-0.330^{* * *}$ & $-0.443^{* * *}$ & $-0.494^{* * *}$ & $-0.629^{* * *}$ & $-0.539^{* * *}$ & $-0.577^{* * *}$ & $-0.636^{\star * *}$ & $-0.599^{* \star *}$ & $-0.700^{* * *}$ & $-0.674^{* * *}$ & $-0.641^{* * *}$ & $-0.637^{* * *}$ & $-0.638^{* * *}$ & $-0.601^{* * *}$ & $-0.629^{* * *}$ & $-0.651^{* * *}$ \\
\hline & $(0.073)$ & $(0.093)$ & $(0.129)$ & $(0.157)$ & $(0.173)$ & $(0.109)$ & $(0.110)$ & $(0.097)$ & $(0.091)$ & $(0.081)$ & $(0.109)$ & $(0.116)$ & $(0.114)$ & $(0.110)$ & $(0.098)$ & $(0.053)$ \\
\hline Country FE & YES & YES & YES & YES & YES & YES & YES & YES & YES & YES & YES & YES & YES & YES & YES & YES \\
\hline CRE price growth lag & YES & YES & YES & YES & YES & YES & YES & YES & YES & YES & YES & YES & YES & YES & YES & YES \\
\hline Observations & 1,845 & 1,818 & 1,790 & 1,762 & 1,734 & 1,706 & 1,676 & 1,646 & 1,616 & 1,586 & 1,556 & 1,526 & 1,496 & 1,466 & 1,436 & 1,406 \\
\hline
\end{tabular}

Note: The tables report the estimated coefficients from the CRE Prices-at-Risk specification described in equation (7) augmented with VIX to test the robustness of the analysis against aggregate time varying effects. The models are estimated using the full sample of core economies. The dependent variable corresponds to the $5^{\text {th }}$ percentile of the average $\mathrm{CRE}$ price growth distribution over the forecasting horizon $\mathrm{h}$. All covariates are standardized so that magnitudes of coefficients indicate relative importance of variables. Standard errors are bootstrapped and shown in parentheses. $* * * \mathrm{p}<0.01, * * \mathrm{p}<0.05$, $* \mathrm{p}<0.1$. 
Table A3.2. Estimating CRE Prices-at-Risk Baseline Model Estimated at Different Percentiles

\begin{tabular}{|c|c|c|c|c|c|c|c|c|c|c|c|c|c|c|c|c|}
\hline Quantile & $h=1$ & $h=2$ & $h=3$ & $h=4$ & $h=5$ & $h=6$ & $h=7$ & $h=8$ & $h=9$ & $h=10$ & $h=11$ & $h=12$ & $h=13$ & $h=14$ & $h=15$ & $h=16$ \\
\hline 5th percentile (baseline) & $\begin{array}{l}-0.346^{\star * *} \\
(0.068)\end{array}$ & $\begin{array}{l}-0.487^{\star \star *} \\
(0.099)\end{array}$ & $\begin{array}{l}-0.572^{\star \star \star} \\
(0.115)\end{array}$ & $\begin{array}{l}-0.578^{\star \star \star} \\
(0.121)\end{array}$ & $\begin{array}{l}-0.593^{\star * *} \\
(0.130)\end{array}$ & $\begin{array}{l}-0.523^{* \star *} \\
(0.107)\end{array}$ & $\begin{array}{l}-0.561^{* * *} \\
(0.143)\end{array}$ & $\begin{array}{l}-0.577^{\star \star \star} \\
(0.059)\end{array}$ & $\begin{array}{l}-0.639^{\star \star *} \\
(0.114)\end{array}$ & $\begin{array}{l}-0.685^{* \star *} \\
(0.090)\end{array}$ & $\begin{array}{l}-0.658^{\star * *} \\
(0.104)\end{array}$ & $\begin{array}{l}-0.648^{* \star *} \\
(0.098)\end{array}$ & $\begin{array}{l}-0.638^{\star \star \star} \\
(0.078)\end{array}$ & $\begin{array}{l}-0.604^{* * *} \\
(0.099)\end{array}$ & $\begin{array}{l}-0.635^{\star \star *} \\
(0.106)\end{array}$ & $\begin{array}{l}-0.647^{* * \star} \\
(0.045)\end{array}$ \\
\hline 10th percentile & $\begin{array}{l}-0.308^{\star \star *} \\
(0.085)\end{array}$ & $\begin{array}{l}-0.323^{\star \star *} \\
(0.079)\end{array}$ & $\begin{array}{l}-0.485^{\star \star \star} \\
(0.125)\end{array}$ & $\begin{array}{l}-0.529^{\star * *} \\
(0.121)\end{array}$ & $\begin{array}{l}-0.545^{\star \star *} \\
(0.093)\end{array}$ & $\begin{array}{l}-0.564^{\star \star *} \\
(0.120)\end{array}$ & $\begin{array}{l}-0.576^{\star \star \star} \\
(0.102)\end{array}$ & $\begin{array}{l}-0.588^{\star \star \star} \\
(0.099)\end{array}$ & $\begin{array}{l}-0.624^{\star * *} \\
(0.089)\end{array}$ & $\begin{array}{l}-0.689^{\star \star *} \\
(0.106)\end{array}$ & $\begin{array}{l}-0.674^{\star \star \star} \\
(0.097)\end{array}$ & $\begin{array}{l}-0.684^{\star \star *} \\
(0.078)\end{array}$ & $\begin{array}{l}-0.709^{\star \star *} \\
(0.075)\end{array}$ & 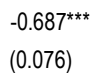 & $\begin{array}{l}-0.689^{* * *} \\
(0.104)\end{array}$ & $\begin{array}{l}-0.688^{* \star \star} \\
(0.074)\end{array}$ \\
\hline 20th percentile & 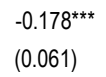 & $\begin{array}{l}-0.233^{* * *} \\
(0.050)\end{array}$ & $\begin{array}{l}-0.298^{\star \star \star} \\
(0.060)\end{array}$ & $\begin{array}{l}-0.356^{\star \star *} \\
(0.097)\end{array}$ & $\begin{array}{l}-0.475^{\star * *} \\
(0.105)\end{array}$ & $\begin{array}{l}-0.509^{* * *} \\
(0.097)\end{array}$ & $\begin{array}{l}-0.572^{\star \star \star} \\
(0.111)\end{array}$ & $\begin{array}{l}-0.610^{* * *} \\
(0.105)\end{array}$ & $\begin{array}{l}-0.627^{* * *} \\
(0.095)\end{array}$ & $\begin{array}{l}-0.668^{* * *} \\
(0.052)\end{array}$ & $\begin{array}{l}-0.710^{\star * *} \\
(0.061)\end{array}$ & $\begin{array}{l}-0.728^{\star \star *} \\
(0.066)\end{array}$ & $\begin{array}{l}-0.738^{* * *} \\
(0.069)\end{array}$ & $\begin{array}{l}-0.743^{\text {** }} \\
(0.052)\end{array}$ & 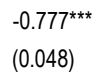 & $\begin{array}{l}-0.775^{* \star \star} \\
(0.046)\end{array}$ \\
\hline Country FE & YES & YES & YES & YES & YES & YES & YES & YES & YES & YES & YES & YES & YES & YES & YES & YES \\
\hline CRE prices growth lag & YES & YES & YES & YES & YES & YES & YES & YES & YES & YES & YES & YES & YES & YES & YES & YES \\
\hline Macro Controls & YES & YES & YES & YES & YES & YES & YES & YES & YES & YES & YES & YES & YES & YES & YES & YES \\
\hline
\end{tabular}

Note: The tables report the coefficients for the CRE price misalignment from CRE Prices-at-Risk specification described in equation (7) estimated at different percentiles of the dependent variable to test the robustness of the baseline results against the choice of a specific percentile. Specifically, the results from the baseline model ( $5^{\text {th }}$ percentile) are compared to the results from the model where the dependent variable correspond to the $10^{\text {th }}$ and $20^{\text {th }}$ percentile of the average CRE price growth distribution over the forecasting horizon h. All covariates are standardized so that magnitudes of coefficients indicate relative importance of variables. Standard errors are bootstrapped and shown in parentheses. ${ }^{* *} \mathrm{p}<0.01,{ }^{* *} \mathrm{p}<0.05,{ }^{*} \mathrm{p}<0.1$.

\section{Table A3.3. Alternative Quantile Estimation Methodology for CRE Prices-at-Risk Baseline Model}

\begin{tabular}{|c|c|c|c|c|c|c|c|c|c|c|c|c|c|c|c|c|}
\hline Estimation methodology & $h=1$ & $h=2$ & $h=3$ & $h=4$ & $h=5$ & $h=6$ & $h=7$ & $h=8$ & $h=9$ & $h=10$ & $h=11$ & $h=12$ & $h=13$ & $h=14$ & $h=15$ & $h=16$ \\
\hline \multirow[t]{2}{*}{$\begin{array}{l}\text { Canay 2-step estimation } \\
\text { (baseline) }\end{array}$} & $-0.346^{\star * \star}$ & $-0.487^{\star \star \star}$ & $-0.572^{\star * \star}$ & $-0.578^{\star \star *}$ & $-0.593^{* \star *}$ & $-0.523^{\star * \star}$ & $-0.561^{* \star *}$ & $-0.577^{\star \star *}$ & $-0.639^{\star * \star}$ & $-0.685^{\star \star \star}$ & $-0.658^{* * \star}$ & $-0.648^{\star \star \star}$ & $-0.638^{\star \star \star}$ & $-0.604^{\star * \star}$ & $-0.635^{\star \star *}$ & $-0.647^{\star \star *}$ \\
\hline & $(0.068)$ & $(0.099)$ & $(0.115)$ & $(0.121)$ & $(0.130)$ & $(0.107)$ & $(0.143)$ & $(0.059)$ & $(0.114)$ & $(0.090)$ & $(0.104)$ & $(0.098)$ & $(0.078)$ & $(0.099)$ & $(0.106)$ & $(0.045)$ \\
\hline \multirow[t]{2}{*}{ Machado and Silva (2019) } & $-0.531^{\star * \star}$ & $-0.669^{\star}$ & $-0.821^{\star *}$ & $-0.884^{\star \star *}$ & $-0.943^{*}$ & $-0.945^{\star * *}$ & $-0.939^{\star \star \star}$ & $-0.944^{* * *}$ & $-0.905^{\star \star}$ & $-0.881^{\star \star \star}$ & $-0.866^{\star * \star}$ & $-0.836^{* * *}$ & $-0.814^{\star \star \star}$ & $-0.814^{* \star}$ & $-0.802^{\star *}$ & $-0.786^{* * *}$ \\
\hline & $(0.179)$ & $(0.342)$ & $(0.330)$ & (0.322) & $(0.542)$ & $(0.282)$ & $(0.243)$ & $(0.295)$ & $(0.411)$ & $(0.187)$ & $(0.163)$ & $(0.162)$ & $(0.149)$ & $(0.406)$ & $(0.337)$ & $(0.277)$ \\
\hline Country FE & YES & YES & YES & YES & YES & YES & YES & YES & YES & YES & YES & YES & YES & YES & YES & YES \\
\hline CRE prices growth lag & YES & YES & YES & YES & YES & YES & YES & YES & YES & YES & YES & YES & YES & YES & YES & YES \\
\hline Macro Controls & YES & YES & YES & YES & YES & YES & YES & YES & YES & YES & YES & YES & YES & YES & YES & YES \\
\hline
\end{tabular}

Note: The tables report the coefficients for the CRE price misalignment from the CRE Prices-at-Risk specification described in equation (7) estimated using an alternative estimation methodology. Specifically, the results from the baseline model using the Cany 2-step estimation procedure are compared to the results from the model estimated using Machado and Silva (2019) estimation methodology. The dependent variable corresponds to the $5^{\text {th }}$ percentile of the future CRE prices growth distribution over the forecasting horizon h. All covariates are standardized so that magnitudes of coefficients indicate relative importance of variables. Standard errors are bootstrapped and shown in parentheses. ${ }^{* * *} \mathrm{p}<0.01,{ }^{* *} \mathrm{p}<0.05, * \mathrm{p}<0.1$. 
Table A3.4. Robustness Analysis: Growth-at-Risk with CRE Price Controlling for Time Effects

\begin{tabular}{|c|c|c|c|c|c|c|c|c|c|c|c|c|c|c|c|c|}
\hline VARIABLES & $h=1$ & $h=2$ & $h=3$ & $h=4$ & $h=5$ & $\mathrm{~h}=6$ & $h=7$ & $h=8$ & $h=9$ & $h=10$ & $h=11$ & $h=12$ & $h=13$ & $h=14$ & $h=15$ & $h=16$ \\
\hline CRE price misalignment & $\begin{array}{l}-0.326^{* *} \\
(0.137)\end{array}$ & $\begin{array}{l}-0.349^{* * *} \\
(0.072)\end{array}$ & $\begin{array}{l}-0.351^{\star * \star} \\
(0.044)\end{array}$ & $\begin{array}{l}-0.311^{\star \star *} \\
(0.040)\end{array}$ & $\begin{array}{l}-0.279^{* * *} \\
(0.029)\end{array}$ & $\begin{array}{l}-0.276^{* * *} \\
(0.024)\end{array}$ & $\begin{array}{l}-0.225^{\star * *} \\
(0.035)\end{array}$ & $\begin{array}{l}-0.207^{\star \star *} \\
(0.037)\end{array}$ & $\begin{array}{l}-0.199^{\star \star \star} \\
(0.029)\end{array}$ & $\begin{array}{l}-0.177^{\star \star \star} \\
(0.027)\end{array}$ & $\begin{array}{l}-0.154^{\star \star *} \\
(0.025)\end{array}$ & $\begin{array}{c}-0.163^{\star \star *} \\
(0.037)\end{array}$ & $\begin{array}{c}-0.163^{* \star \star} \\
(0.029)\end{array}$ & $\begin{array}{c}-0.168^{* * *} \\
(0.026)\end{array}$ & $\begin{array}{c}-0.167^{\star \star \star} \\
(0.025)\end{array}$ & $\begin{array}{c}-0.181^{* * \star} \\
(0.020)\end{array}$ \\
\hline Financial condition index & $\begin{array}{r}-0.027 \\
(0.116)\end{array}$ & $\begin{array}{r}-0.106 \\
(0.112)\end{array}$ & $\begin{array}{r}-0.207 \\
(0.152)\end{array}$ & $\begin{array}{c}-0.115 \\
(0.106)\end{array}$ & $\begin{array}{r}-0.091 \\
(0.068)\end{array}$ & $\begin{array}{c}-0.008 \\
(0.057)\end{array}$ & $\begin{array}{r}0.082 \\
(0.057)\end{array}$ & $\begin{array}{r}0.069 \\
(0.060)\end{array}$ & $\begin{array}{c}0.099^{*} \\
(0.054)\end{array}$ & $\begin{array}{r}0.031 \\
(0.042)\end{array}$ & $\begin{array}{r}0.020 \\
(0.040)\end{array}$ & $\begin{array}{c}-0.003 \\
(0.053)\end{array}$ & $\begin{array}{r}-0.009 \\
(0.037)\end{array}$ & $\begin{array}{l}-0.003 \\
(0.055)\end{array}$ & $\begin{array}{l}-0.020 \\
(0.046)\end{array}$ & $\begin{array}{l}-0.016 \\
(0.040)\end{array}$ \\
\hline House prices growth & $\begin{array}{l}0.245^{\star \star \star} \\
(0.089)\end{array}$ & $\begin{array}{l}0.343^{* * *} \\
(0.067)\end{array}$ & $\begin{array}{l}0.354^{* * *} \\
(0.126)\end{array}$ & $\begin{array}{l}0.338^{* * *} \\
(0.056)\end{array}$ & $\begin{array}{l}0.309^{* * *} \\
(0.051)\end{array}$ & $\begin{array}{l}0.268^{* \star *} \\
(0.058)\end{array}$ & $\begin{array}{l}0.284^{* * *} \\
(0.049)\end{array}$ & $\begin{array}{l}0.218^{* * *} \\
(0.050)\end{array}$ & $\begin{array}{l}0.233^{* * *} \\
(0.031)\end{array}$ & $\begin{array}{l}0.214^{* * *} \\
(0.023)\end{array}$ & $\begin{array}{l}0.174^{\star \star *} \\
(0.022)\end{array}$ & $\begin{array}{l}0.139^{\star * \star} \\
(0.029)\end{array}$ & $\begin{array}{c}0.155^{\star \star \star} \\
(0.025)\end{array}$ & $\begin{array}{c}0.138^{* * *} \\
(0.026)\end{array}$ & $\begin{array}{l}0.121^{* * *} \\
(0.022)\end{array}$ & $\begin{array}{c}0.126^{\star * \star} \\
(0.025)\end{array}$ \\
\hline Credit-to-GDP gap & $\begin{array}{l}-0.583^{* \star *} \\
(0.113)\end{array}$ & $\begin{array}{l}-0.466^{* * *} \\
(0.078)\end{array}$ & $\begin{array}{l}-0.370^{\star \star *} \\
(0.127)\end{array}$ & $\begin{array}{l}-0.371^{\star \star *} \\
(0.069)\end{array}$ & $\begin{array}{l}-0.333^{\star * *} \\
(0.059)\end{array}$ & $\begin{array}{l}-0.330^{* * *} \\
(0.042)\end{array}$ & $\begin{array}{l}-0.268^{* * *} \\
(0.058)\end{array}$ & $\begin{array}{l}-0.326^{\star * *} \\
(0.060)\end{array}$ & $\begin{array}{l}-0.347^{\star \star \star} \\
(0.039)\end{array}$ & $\begin{array}{l}-0.301^{* * *} \\
(0.033)\end{array}$ & $\begin{array}{l}-0.291^{\star \star *} \\
(0.049)\end{array}$ & $\begin{array}{c}-0.292^{\star \star *} \\
(0.056)\end{array}$ & $\begin{array}{c}-0.289^{\star \star *} \\
(0.047)\end{array}$ & $\begin{array}{c}-0.283^{* * *} \\
(0.041)\end{array}$ & $\begin{array}{c}-0.258^{* * *} \\
(0.032)\end{array}$ & $\begin{array}{c}-0.230^{* * \star} \\
(0.029)\end{array}$ \\
\hline VIX & $\begin{array}{l}-0.890^{* * *} \\
(0.197)\end{array}$ & $\begin{array}{c}-0.154 \\
(0.130)\end{array}$ & $\begin{array}{r}0.113 \\
(0.131)\end{array}$ & $\begin{array}{r}0.027 \\
(0.108)\end{array}$ & $\begin{array}{r}0.001 \\
(0.088)\end{array}$ & $\begin{array}{l}-0.246^{* * *} \\
(0.087)\end{array}$ & $\begin{array}{c}-0.066 \\
(0.070)\end{array}$ & $\begin{array}{r}0.013 \\
(0.050)\end{array}$ & $\begin{array}{c}-0.005 \\
(0.046)\end{array}$ & $\begin{array}{c}0.073^{*} \\
(0.041)\end{array}$ & $\begin{array}{c}0.103^{* *} \\
(0.043)\end{array}$ & $\begin{array}{l}0.113^{* \star *} \\
(0.043)\end{array}$ & $\begin{array}{l}0.096^{* *} \\
(0.042)\end{array}$ & $\begin{array}{l}0.091^{* *} \\
(0.042)\end{array}$ & $\begin{array}{l}0.117^{* *} \\
(0.046)\end{array}$ & $\begin{array}{l}0.085^{5 *} \\
(0.037)\end{array}$ \\
\hline Country FE & YES & YES & YES & YES & YES & YES & YES & YES & YES & YES & YES & YES & YES & YES & YES & YES \\
\hline GDP growth lag & YES & YES & YES & YES & YES & YES & YES & YES & YES & YES & YES & YES & YES & YES & YES & YES \\
\hline Observations & 1,792 & 1,792 & 1,785 & 1,757 & 1,730 & 1,703 & 1,676 & 1,648 & 1,620 & 1,592 & 1,564 & 1,536 & 1,508 & 1,480 & 1,452 & 1,424 \\
\hline
\end{tabular}

Note: The tables report the estimated coefficients from the Growth-at-Risk specification described in equation (9) augmented with VIX to test the robustness of the analysis against aggregate time varying effects. The models are estimated using the full sample of core economies. The dependent variable corresponds to the $5^{\text {th }}$ percentile of the average GDP growth distribution over the forecasting horizon $\mathrm{h}$. All covariates are standardized so that magnitudes of coefficients indicate relative importance of variables. Standard errors are bootstrapped and shown in parentheses. $* * * \mathrm{p}<0.01, * * \mathrm{p}<0.05,{ }^{*} \mathrm{p}<0.1$. 
Table A3.5. Robustness Analysis: Growth-at-Risk with CRE Price Misalignment Estimated at Different Percentiles

\begin{tabular}{|c|c|c|c|c|c|c|c|c|c|c|c|c|c|c|c|c|}
\hline Quantile & $h=1$ & $h=2$ & $h=3$ & $h=4$ & $h=5$ & $h=6$ & $h=7$ & $h=8$ & $h=9$ & $h=10$ & $h=11$ & $h=12$ & $h=13$ & $h=14$ & $h=15$ & $h=16$ \\
\hline 5th percentile (baseline) & $\begin{array}{l}-0.423^{\star \star *} \\
(0.069)\end{array}$ & $\begin{array}{l}-0.372^{\star \star *} \\
(0.058)\end{array}$ & $\begin{array}{l}-0.331^{\star * *} \\
(0.041)\end{array}$ & $\begin{array}{l}-0.311^{\star \star *} \\
(0.040)\end{array}$ & $\begin{array}{l}-0.271^{\star * *} \\
(0.028)\end{array}$ & $\begin{array}{l}-0.280^{\star * *} \\
(0.028)\end{array}$ & $\begin{array}{l}-0.230^{* * *} \\
(0.033)\end{array}$ & $\begin{array}{l}-0.212^{\star \star \star} \\
(0.030)\end{array}$ & $\begin{array}{l}-0.197^{\star \star \star} \\
(0.039)\end{array}$ & $\begin{array}{l}-0.180^{\star * *} \\
(0.029)\end{array}$ & $\begin{array}{l}-0.148^{\star \star *} \\
(0.040)\end{array}$ & $\begin{array}{l}-0.163^{\star \star \star} \\
(0.033)\end{array}$ & $\begin{array}{l}-0.167^{\star \star \star} \\
(0.027)\end{array}$ & $\begin{array}{l}-0.171^{\star * \star} \\
(0.023)\end{array}$ & $\begin{array}{l}-0.178^{\star \star *} \\
(0.029)\end{array}$ & $\begin{array}{l}-0.187^{\star \star *} \\
(0.025)\end{array}$ \\
\hline 10th percentile & $\begin{array}{l}-0.292^{\star \star \star} \\
(0.053)\end{array}$ & $\begin{array}{l}-0.250^{\star \star \star} \\
(0.056)\end{array}$ & $\begin{array}{l}-0.249^{\star \star *} \\
(0.037)\end{array}$ & $\begin{array}{l}-0.275^{\star \star \star} \\
(0.041)\end{array}$ & $\begin{array}{l}-0.239^{\star \star *} \\
(0.037)\end{array}$ & $\begin{array}{l}-0.241^{\star \star *} \\
(0.032)\end{array}$ & $\begin{array}{l}-0.220^{\star * *} \\
(0.025)\end{array}$ & $\begin{array}{l}-0.194^{\star \star *} \\
(0.031)\end{array}$ & $\begin{array}{l}-0.192^{\star \star *} \\
(0.029)\end{array}$ & $\begin{array}{l}-0.159^{\star \star *} \\
(0.036)\end{array}$ & $\begin{array}{l}-0.155^{\star \star *} \\
(0.033)\end{array}$ & $\begin{array}{l}-0.149^{\star \star \star *} \\
(0.036)\end{array}$ & $\begin{array}{l}-0.135^{\star * \star} \\
(0.033)\end{array}$ & $\begin{array}{l}-0.139^{\star \star \star} \\
(0.048)\end{array}$ & $\begin{array}{l}-0.141^{\star \star \star} \\
(0.044)\end{array}$ & $\begin{array}{l}-0.154^{* \star *} \\
(0.045)\end{array}$ \\
\hline 20th percentile & $\begin{array}{l}-0.153^{* \star *} \\
(0.047)\end{array}$ & $\begin{array}{l}-0.133^{* \star *} \\
(0.029)\end{array}$ & $\begin{array}{l}-0.182^{* * *} \\
(0.030)\end{array}$ & $\begin{array}{l}-0.171^{* * *} \\
(0.024)\end{array}$ & $\begin{array}{l}-0.179^{* * *} \\
(0.024)\end{array}$ & $\begin{array}{l}-0.176^{* * *} \\
(0.025)\end{array}$ & $\begin{array}{l}-0.185^{\star * \star} \\
(0.027)\end{array}$ & $\begin{array}{l}-0.190^{* * *} \\
(0.025)\end{array}$ & $\begin{array}{l}-0.189^{\star \star \star *} \\
(0.019)\end{array}$ & $\begin{array}{l}-0.169^{* * *} \\
(0.018)\end{array}$ & $\begin{array}{l}-0.158^{\star * *} \\
(0.016)\end{array}$ & $\begin{array}{l}-0.155^{\star \star *} \\
(0.017)\end{array}$ & $\begin{array}{l}-0.148^{* * *} \\
(0.016)\end{array}$ & $\begin{array}{l}-0.143^{* \star \star} \\
(0.019)\end{array}$ & $\begin{array}{l}-0.139^{\star \star \star} \\
(0.019)\end{array}$ & $\begin{array}{l}-0.146^{* \star *} \\
(0.022)\end{array}$ \\
\hline Country FE & YES & YES & YES & YES & YES & YES & YES & YES & YES & YES & YES & YES & YES & YES & YES & YES \\
\hline GDP growth lag & YES & YES & YES & YES & YES & YES & YES & YES & YES & YES & YES & YES & YES & YES & YES & YES \\
\hline Macro Controls & YES & YES & YES & YES & YES & YES & YES & YES & YES & YES & YES & YES & YES & YES & YES & YES \\
\hline Observations & 1,792 & 1,792 & 1,785 & 1,757 & 1,730 & 1,703 & 1,676 & 1,648 & 1,620 & 1,592 & 1,564 & 1,536 & 1,508 & 1,480 & 1,452 & 1,424 \\
\hline
\end{tabular}

Note: The tables report the coefficients for the CRE price misalignment from Growth-at-Risk specification described in equation (9) estimated at different percentiles of the dependent variable to test the robustness of the baseline results against the choice of a specific percentile. Specifically, the results from the baseline model ( $5^{\text {th }}$ percentile) are compared to the results from the model where the dependen variable correspond to the $10^{\text {th }}$ and $20^{\text {th }}$ percentile of the average GDP growth distribution over the forecasting horizon $\mathrm{h}$. All covariates are standardized so that magnitudes of coefficients indicate relative importance of variables. Standard errors are bootstrapped and shown in parentheses. ${ }^{* * *} \mathrm{p}<0.01,{ }^{* *} \mathrm{p}<0.05,{ }^{*} \mathrm{p}<0.1$.

\section{Table A3.6. Alternative Estimation Methodology for Growth-at-Risk Model}

\begin{tabular}{|c|c|c|c|c|c|c|c|c|c|c|c|c|c|c|c|c|}
\hline Estimation methodology & $h=1$ & $h=2$ & $h=3$ & $h=4$ & $h=5$ & $h=6$ & $h=7$ & $h=8$ & $h=9$ & $h=10$ & $h=11$ & $h=12$ & $h=13$ & $h=14$ & $h=15$ & $h=16$ \\
\hline Canay 2-step estimation (baseline) & $\begin{array}{l}-0.423^{\star * *} \\
(0.069)\end{array}$ & $\begin{array}{l}-0.372^{\star * *} \\
(0.058)\end{array}$ & $\begin{array}{l}-0.331^{\star * *} \\
(0.041)\end{array}$ & $\begin{array}{l}-0.311^{\star * *} \\
(0.040)\end{array}$ & $\begin{array}{l}-0.271^{\star * *} \\
(0.028)\end{array}$ & $\begin{array}{l}-0.280^{\star \star *} \\
(0.028)\end{array}$ & $\begin{array}{l}-0.230^{\star \star \star} \\
(0.033)\end{array}$ & $\begin{array}{l}-0.212^{\star \star \star} \\
(0.030)\end{array}$ & $\begin{array}{l}-0.197^{\star \star \star} \\
(0.039)\end{array}$ & $\begin{array}{l}-0.180^{\star \star *} \\
(0.029)\end{array}$ & $\begin{array}{l}-0.148^{* \star *} \\
(0.040)\end{array}$ & $\begin{array}{l}-0.163^{\star \star \star} \\
(0.033)\end{array}$ & $\begin{array}{l}-0.167^{* \star *} \\
(0.027)\end{array}$ & $\begin{array}{l}-0.171^{\star * \star} \\
(0.023)\end{array}$ & $\begin{array}{l}-0.178^{\star \star \star} \\
(0.029)\end{array}$ & $\begin{array}{l}-0.187^{\star \star \star} \\
(0.025)\end{array}$ \\
\hline Machado and Silva & $\begin{array}{l}-0.343^{* \star} \\
(0.174)\end{array}$ & $\begin{array}{l}-0.367^{* *} \\
(0.155)\end{array}$ & $\begin{array}{l}-0.345^{\star \star \star} \\
(0.132)\end{array}$ & $\begin{array}{l}-0.303^{* \star *} \\
(0.091)\end{array}$ & $\begin{array}{l}-0.256^{\star \star \star} \\
(0.083)\end{array}$ & $\begin{array}{l}-0.231^{\star * *} \\
(0.069)\end{array}$ & $\begin{array}{l}-0.211^{* * *} \\
(0.068)\end{array}$ & $\begin{array}{l}-0.180^{\star \star *} \\
(0.064)\end{array}$ & $\begin{array}{l}-0.173^{\star \star \star} \\
(0.063)\end{array}$ & $\begin{array}{l}-0.155^{* *} \\
(0.063)\end{array}$ & $\begin{array}{l}-0.140^{* *} \\
(0.057)\end{array}$ & $\begin{array}{l}-0.137^{\star *} \\
(0.055)\end{array}$ & $\begin{array}{l}-0.135^{\star *} \\
(0.053)\end{array}$ & $\begin{array}{l}-0.135^{\star \star *} \\
(0.049)\end{array}$ & $\begin{array}{l}-0.139^{* * *} \\
(0.047)\end{array}$ & $\begin{array}{l}-0.150^{\star \star \star *} \\
(0.045)\end{array}$ \\
\hline Country FE & YES & YES & YES & YES & YES & YES & YES & YES & YES & YES & YES & YES & YES & YES & YES & YES \\
\hline GDP growth lag & YES & YES & YES & YES & YES & YES & YES & YES & YES & YES & YES & YES & YES & YES & YES & YES \\
\hline Macro Controls & YES & YES & YES & YES & YES & YES & YES & YES & YES & YES & YES & YES & YES & YES & YES & YES \\
\hline Observations & 1,792 & 1,792 & 1,785 & 1,757 & 1,730 & 1,703 & 1,676 & 1,648 & 1,620 & 1,592 & 1,564 & 1,536 & 1,508 & 1,480 & 1,452 & 1,424 \\
\hline
\end{tabular}

Note: The tables report the coefficients for the CRE price misalignment from the Growth-at-Risk specification described in equation (9) estimated using an alternative estimation methodology. Specifically, the results from the baseline model using the Cany 2-step estimation procedure are compared to the results from the model estimated using Machado and Silva (2019) estimation methodology. The dependent variable corresponds to the $5^{\text {th }}$ percentile of the average GDP growth distribution over the forecasting horizon $\mathrm{h}$. All covariates are standardized so that magnitudes of coefficients indicate relative importance of variables. Standard errors are bootstrapped and shown in parentheses. ${ }^{* * *} \mathrm{p}<0.01,{ }^{* *} \mathrm{p}<0.05,{ }^{*} \mathrm{p}<0.1$. 
Table A3.7. Robustness Analysis: Growth-at-Risk with CRE Price with asymmetric CRE Price Misalignment effects

\begin{tabular}{|c|c|c|c|c|c|c|c|c|c|c|c|c|c|c|c|c|}
\hline VARIABLES & $h=1$ & $h=2$ & $h=3$ & $\mathrm{~h}=4$ & $\mathrm{~h}=5$ & $h=6$ & $\mathrm{~h}=7$ & $h=8$ & $h=9$ & $h=10$ & $h=11$ & $h=12$ & $h=13$ & $h=14$ & $h=15$ & $h=16$ \\
\hline CRE price misalignment & -0.033 & -0.066 & -0.051 & -0.011 & -0.017 & 0.066 & 0.049 & $0.095^{*}$ & $0.103^{* \star *}$ & $0.118^{\star \star *}$ & $0.096^{* *}$ & $0.107^{\star}$ & 0.065 & 0.031 & -0.002 & -0.030 \\
\hline CRE price misalignment $X$ & $(0.150)$ & $(0.067)$ & $(0.097)$ & $(0.066)$ & $(0.063)$ & $(0.063)$ & $(0.045)$ & $(0.056)$ & $(0.036)$ & $(0.036)$ & $(0.044)$ & $(0.058)$ & $(0.050)$ & $(0.035)$ & $(0.053)$ & $(0.036)$ \\
\hline Positive CRE pric & $\begin{array}{c}-0.734^{* *} \\
(0.368)\end{array}$ & $\begin{array}{c}-0.687^{* *} \\
(0.290)\end{array}$ & $\begin{array}{c}-0.282^{* *} \\
(0.131)\end{array}$ & $\begin{array}{c}-0.398^{* * *} \\
(0.120)\end{array}$ & $\begin{array}{c}-0.343^{* *} \\
(0.141)\end{array}$ & $\begin{array}{c}-0.350^{* * *} \\
(0.072)\end{array}$ & $\begin{array}{c}-0.332^{* * *} \\
(0.080)\end{array}$ & $\begin{array}{c}-0.359^{\star \star \star} \\
(0.062)\end{array}$ & $\begin{array}{c}-0.336^{* \star *} \\
(0.047)\end{array}$ & $\begin{array}{c}-0.338^{\star * *} \\
(0.041)\end{array}$ & $\begin{array}{c}-0.295^{\star * *} \\
(0.035)\end{array}$ & $\begin{array}{c}-0.273^{* * *} \\
(0.047)\end{array}$ & $\begin{array}{c}-0.249^{\star * *} \\
(0.043)\end{array}$ & $\begin{array}{c}-0.207^{\star \star *} \\
(0.035)\end{array}$ & $\begin{array}{c}-0.176^{\star * *} \\
(0.055)\end{array}$ & $\begin{array}{c}-0.154^{\star \star \star} \\
(0.036)\end{array}$ \\
\hline Financial conditions index & $\begin{array}{c}-0.395^{\star \star *} \\
(0.122)\end{array}$ & $\begin{array}{c}-0.276^{\star \star *} \\
(0.100)\end{array}$ & $\begin{array}{c}-0.186^{*} \\
(0.096)\end{array}$ & $\begin{array}{c}-0.161^{\star \star \star} \\
(0.044)\end{array}$ & $\begin{array}{c}-0.147^{\star * *} \\
(0.050)\end{array}$ & $\begin{array}{c}-0.158^{\star * \star} \\
(0.049)\end{array}$ & $\begin{array}{l}-0.056 \\
(0.055)\end{array}$ & $\begin{array}{l}-0.026 \\
(0.051)\end{array}$ & $\begin{array}{c}0.027 \\
(0.054)\end{array}$ & $\begin{array}{c}0.032 \\
(0.038)\end{array}$ & $\begin{array}{c}0.048 \\
(0.037)\end{array}$ & $\begin{array}{c}0.039 \\
(0.032)\end{array}$ & $\begin{array}{l}0.052^{*} \\
(0.029)\end{array}$ & $\begin{array}{c}0.033 \\
(0.025)\end{array}$ & $\begin{array}{l}0.055^{\star} \\
(0.031)\end{array}$ & $\begin{array}{c}0.045 \\
(0.028)\end{array}$ \\
\hline House prices growth & $\begin{array}{l}0.288^{* *} \\
(0.130)\end{array}$ & $\begin{array}{c}0.249^{\star \star \star} \\
(0.085)\end{array}$ & $\begin{array}{c}0.267^{\star \star \star} \\
(0.085)\end{array}$ & $\begin{array}{c}0.237^{\star * \star} \\
(0.063)\end{array}$ & $\begin{array}{c}0.205^{\star \star \star} \\
(0.057)\end{array}$ & $\begin{array}{l}0.150^{\star \star \star} \\
(0.054)\end{array}$ & $\begin{array}{l}0.182^{\star \star \star} \\
(0.054)\end{array}$ & $\begin{array}{l}0.145^{\star \star *} \\
(0.036)\end{array}$ & $\begin{array}{l}0.160^{\star \star \star} \\
(0.035)\end{array}$ & $\begin{array}{c}0.140^{\star * \star} \\
(0.023)\end{array}$ & $\begin{array}{l}0.113^{* \star \star} \\
(0.025)\end{array}$ & $\begin{array}{l}0.065^{* *} \\
(0.027)\end{array}$ & $\begin{array}{l}0.097^{* *} \\
(0.040)\end{array}$ & $\begin{array}{c}0.082^{\star \star \star} \\
(0.028)\end{array}$ & $\begin{array}{l}0.087^{\star \star} \\
(0.043)\end{array}$ & $\begin{array}{c}0.084^{\star \star \star *} \\
(0.021)\end{array}$ \\
\hline Credit-to-GDP gap & $\begin{array}{l}-0.332^{* *} \\
(0.152)\end{array}$ & $\begin{array}{c}-0.343^{\star \star \star *} \\
(0.102)\end{array}$ & $\begin{array}{c}-0.237^{\star *} \\
(0.106)\end{array}$ & $\begin{array}{c}-0.221^{* * *} \\
(0.071)\end{array}$ & $\begin{array}{c}-0.197^{\star \star \star *} \\
(0.066)\end{array}$ & $\begin{array}{c}-0.189^{* * \star} \\
(0.051)\end{array}$ & $\begin{array}{c}-0.182^{* * \star} \\
(0.056)\end{array}$ & $\begin{array}{c}-0.178^{* \star \star} \\
(0.053)\end{array}$ & $\begin{array}{c}-0.179^{* * *} \\
(0.040)\end{array}$ & $\begin{array}{c}-0.168^{\star \star \star *} \\
(0.036)\end{array}$ & $\begin{array}{c}-0.176^{\star \star \star \star} \\
(0.055)\end{array}$ & $\begin{array}{c}-0.197^{\star \star \star} \\
(0.049)\end{array}$ & $\begin{array}{c}-0.193^{* * *} \\
(0.045)\end{array}$ & $\begin{array}{c}-0.191^{* * *} \\
(0.041)\end{array}$ & $\begin{array}{c}-0.210^{* \star *} \\
(0.035)\end{array}$ & $\begin{array}{c}-0.174^{\star \star *} \\
(0.035)\end{array}$ \\
\hline Positive CRE price misalignment & $\begin{array}{c}0.045 \\
(0.146)\end{array}$ & $\begin{array}{l}-0.102 \\
(0.148)\end{array}$ & $\begin{array}{c}-0.329^{* *} \\
(0.143)\end{array}$ & $\begin{array}{l}-0.238^{* *} \\
(0.094)\end{array}$ & $\begin{array}{c}-0.187^{\star *} \\
(0.092)\end{array}$ & $\begin{array}{c}-0.218^{\star \star *} \\
(0.068)\end{array}$ & $\begin{array}{l}-0.147^{\star *} \\
(0.066)\end{array}$ & $\begin{array}{l}-0.143^{* *} \\
(0.057)\end{array}$ & $\begin{array}{l}-0.104^{\star *} \\
(0.052)\end{array}$ & $\begin{array}{l}-0.106^{*} \\
(0.056)\end{array}$ & $\begin{array}{l}-0.082 \\
(0.052)\end{array}$ & $\begin{array}{l}-0.088^{*} \\
(0.053)\end{array}$ & $\begin{array}{l}-0.091^{\star} \\
(0.047)\end{array}$ & $\begin{array}{c}-0.084^{* *} \\
(0.039)\end{array}$ & $\begin{array}{l}-0.049 \\
(0.031)\end{array}$ & $\begin{array}{l}-0.053 \\
(0.033)\end{array}$ \\
\hline Country FE & YES & YES & YES & YES & YES & YES & YES & YES & YES & YES & YES & YES & YES & YES & YES & YES \\
\hline GDP growth lag & YES & YES & YES & YES & YES & YES & YES & YES & YES & YES & YES & YES & YES & YES & YES & YES \\
\hline Observations & 1,792 & 1,792 & 1,785 & 1,757 & 1,730 & 1,703 & 1,676 & 1,648 & 1,620 & 1,592 & 1,564 & 1,536 & 1,508 & 1,480 & 1,452 & 1,424 \\
\hline
\end{tabular}

Note: The tables report the estimated coefficients from the Growth-at-Risk specification described in equation (9) augmented with an interaction term between CRE prices misalignment and an indicator variable equal to 1 when the misalignment is positive to test asymmetric effect of CRE price misalignment depending on its sign. The models are estimated using the full sample of core economies. The dependent variable corresponds to the $5^{\text {th }}$ percentile of the average GDP growth distribution over the forecasting horizon h. All covariates are standardized so that magnitudes of coefficients indicate relative importance of variables. Standard errors are bootstrapped and shown in parentheses. ${ }^{* * *} \mathrm{p}<0.01,{ }^{* *} \mathrm{p}<0.05,{ }^{*} \mathrm{p}<0.1$. 


\section{Annex 4. Macroprudential Policies and Downside Risks to CRE Prices}

Table A4.1. CRE-Specific Macroprudential Policies

\begin{tabular}{|c|c|c|}
\hline Country & Date & Description \\
\hline Denmark & Jun. 2003 & $\begin{array}{l}60 \% \text { LTV limit on recreational dwellings, office properties and retailing properties, } \\
\text { industrial properties and craftsman's properties, collective energy-supply plants. }\end{array}$ \\
\hline $\begin{array}{l}\text { Hong Kong } \\
\text { SAR }\end{array}$ & Feb. 2013 & $10 \mathrm{pp}$ lower LTV limit on mortgage loans for all commercial and industrial properties \\
\hline $\begin{array}{l}\text { Hong Kong } \\
\text { SAR }\end{array}$ & May 2017 & $\begin{array}{l}\text { Lower the applicable DSR limit by } 10 \text { percentage points for mortgage to borrowers whose } \\
\text { income is mainly derived from outside of Hong Kong SAR }\end{array}$ \\
\hline Indonesia & Jun. 2012 & $\begin{array}{l}\text { LTV limit of } 70 \% \text { on } 2 \text { nd loan for an office/shop house; } 60 \% \text { for } 3 \text { rd or more loans for an } \\
\text { office/shop house }\end{array}$ \\
\hline Indonesia & Jun. 2015 & Lifting LTV ratio for property (including office houses) loans \\
\hline Indonesia & Aug. 2016 & $\begin{array}{l}\text { Lifting LTV limit on office houses based on banks' internal policy (first loan), } 85 \% \text { (second } \\
\text { loan), } 80 \% \text { (third loan or more) }\end{array}$ \\
\hline Indonesia & Jun. 2018 & Lifting regulatory limits on the first mortgage on home stores/home offices \\
\hline Ireland & Jan. 2007 & Minimum risk weight on commercial property lending increased from $50 \%$ to $100 \%$ \\
\hline Ireland & Jan. 2014 & $\begin{array}{l}\text { Minimum risk weight applied to commercial property lending was increased to } 100 \% \text { from } \\
50 \%\end{array}$ \\
\hline Norway & Sep. 2014 & Risk weight of $100 \%$ on CRE lending for banks using the standardized approach \\
\hline Poland & Jan. 2005 & $100 \%$ risk weight on non-residential property \\
\hline Poland & Jun. 2014 & $\begin{array}{l}75 \% \text { or } 80 \% \text { LTV limit on CRE loans if the part above } 75 \% \text { is insured or collateralized with } \\
\text { funds on bank account, government or NBP securities }\end{array}$ \\
\hline Poland & Dec. 2017 & $\begin{array}{l}\text { For banks using the Standardized Approach to determine capital requirement: } 100 \% \text { risk } \\
\text { weight on exposures secured by commercial immovable property located in Poland }\end{array}$ \\
\hline Singapore & Jan. 2013 & Seller's stamp duties for industrial properties \\
\hline Singapore & Jun. 2013 & $\begin{array}{l}\text { Total Debt Servicing Ratio (TDSR) to the loan applied for both residential and } \\
\text { nonresidential property (e.g., industrial and commercial property), and covers property both } \\
\text { in- and outside of Singapore }\end{array}$ \\
\hline Spain & May. 2008 & $\begin{array}{l}\text { Stringent capital requirements on commercial real estate and residential real estate } \\
\text { exposures }\end{array}$ \\
\hline Sweden & Jan. 2014 & $\begin{array}{l}\text { Risk-weight floor framework for commercial mortgages at } 100 \% \text { for exposures calculated } \\
\text { according to the standardized approach for credit risk }\end{array}$ \\
\hline $\begin{array}{l}\text { United } \\
\text { Kingdom }\end{array}$ & Jan. 2014 & $\begin{array}{l}\text { Stricter criterion requirement for firms to determine whether the annual average loss rates } \\
\text { for lending secured by mortgage on commercial real estate in the UK did not exceed } 0.5 \% \\
\text { over a representative period }\end{array}$ \\
\hline $\begin{array}{l}\text { United } \\
\text { Kingdom }\end{array}$ & Oct. 2014 & $\begin{array}{l}\text { Stricter criteria for the eligibility of the } 50 \% \text { risk weight (RW) exposures fully and } \\
\text { completely secured by mortgages on commercial real estate located in non-EEA country } \\
\text { entered into force }\end{array}$ \\
\hline $\begin{array}{l}\text { United } \\
\text { States }\end{array}$ & Dec.2006 & Guidance to banks with high CRE risk concentrations to tighten managerial controls \\
\hline $\begin{array}{l}\text { United } \\
\text { States }\end{array}$ & Jan. 2015 & $150 \%$ risk weight on HVCRE exposure held by a banking organization \\
\hline $\begin{array}{l}\text { United } \\
\text { States }\end{array}$ & Dec.2016 & $\begin{array}{l}\text { Implementation of risk retention rule. The risk retention rules require that at least one } \\
\text { sponsor of a securitization (or its majority owned affiliate) retain a } 5 \text { percent interest in the } \\
\text { credit risk of the securitized assets. }\end{array}$ \\
\hline
\end{tabular}




\section{A4.2 Effect on Macroprudential Policies on CRE Price Misalignment}

We evaluate the association between macroprudential measures and CRE prices misalignment with the following panel quantile model:

$$
\Delta_{h} Y_{i, t, \tau}=\alpha_{i, \tau}^{h}+\beta_{\tau}^{h} \mathrm{MPP}+\gamma_{\tau}^{h} M P_{i, t}+\theta_{\tau}^{h} \text { Controls }_{i, t-1}+\epsilon_{i, t, \tau}^{h} \quad(A 4.2 .1)
$$

Where $\Delta_{h} Y_{i, t, \tau}$ is the change in CRE price misalignment from $t$ to $t+h$ and $M P P$ indicates CREspecific macroprudential measures. As in the equation (11), CRE-specific measures are defined as categorical variable taking values $\{--1,0,1\}$ if there was a loosening action, no change or a tightening action in a quarter and are purged of credit-to-GDP ratio to address potential endogeneity concerns. Figure A4.2.1 shows the coefficient $\beta_{\tau}^{h}$ across different time horizons. Table A4.2.1 reports full regression results. The findings suggest that macroprudential policies have an important role in curtailing CRE prices misalignment.

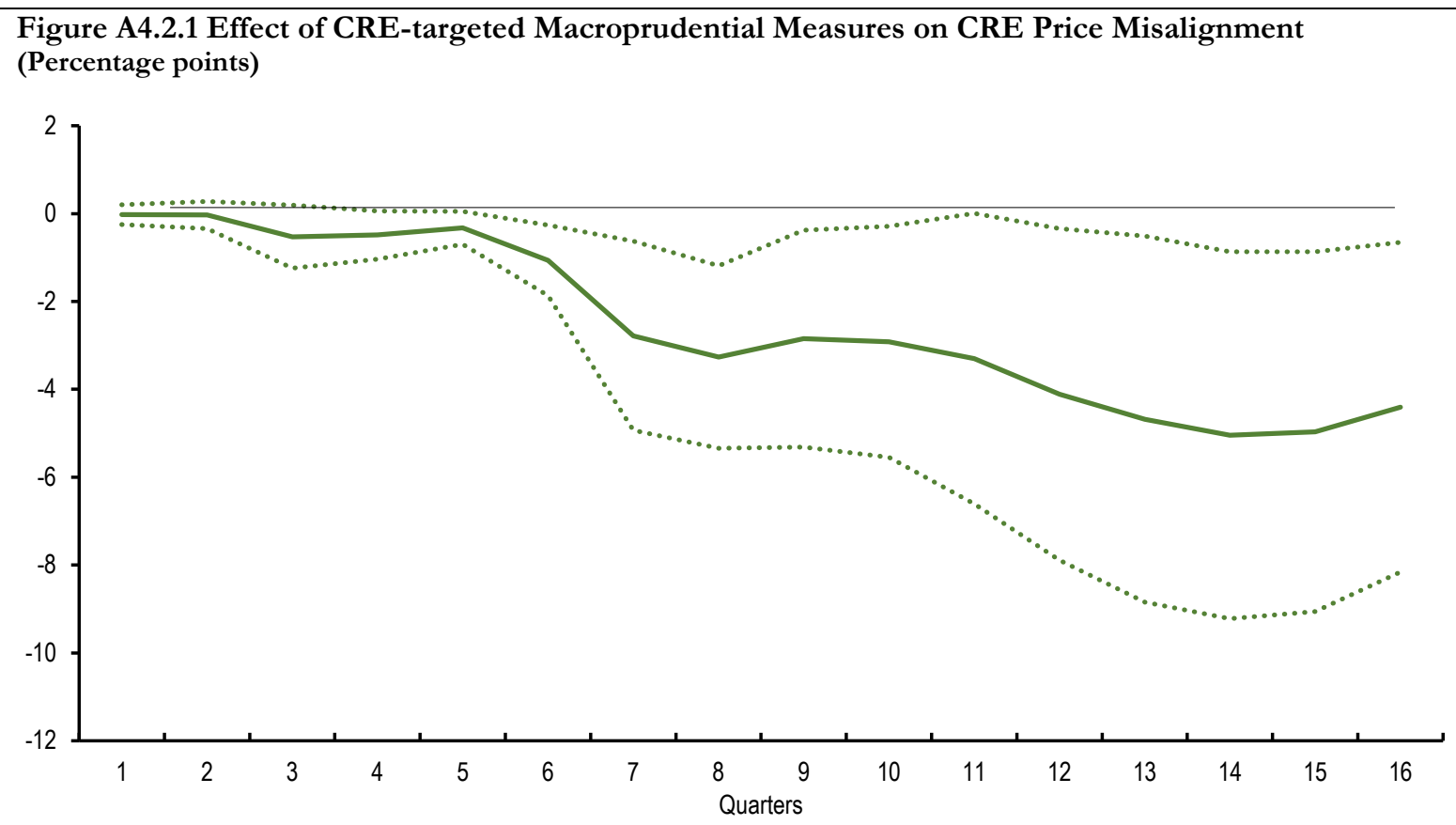

Sources: Haver; MSCI; and authors' calculations.

Note: The dependent variable is defined as the 5th percentile of the future (average) commercial real estate (CRE) price misalignment change distribution. Dotted lines indicate 90 percent confidence intervals. 
Table A4.2.1 Effect of CRE-Specific Macroprudential Measures on CRE Price Misalignment

\begin{tabular}{|c|c|c|c|c|c|c|c|c|c|c|c|c|c|c|c|c|}
\hline VARIABLES & $h=1$ & $h=2$ & $h=3$ & $h=4$ & $h=5$ & $h=6$ & $h=7$ & $h=8$ & $h=9$ & $h=10$ & $h=11$ & $\mathrm{~h}=12$ & $h=13$ & $h=14$ & $h=15$ & $h=16$ \\
\hline $\operatorname{VIX}(-1)$ & -0.900 & $-3.867^{\star \star}$ & $-4.937^{\star}$ & $-3.868^{* *}$ & -2.946 & -2.208 & -1.832 & -0.915 & -0.333 & 0.299 & 2.809 & $5.922^{*}$ & $5.786^{* *}$ & $5.691^{\star \star \star}$ & $6.925^{\star \star \star}$ & $8.784^{\star \star \star}$ \\
\hline Central bank balance sheet & $(0.907)$ & $(1.651)$ & $(2.947)$ & $(1.940)$ & $(2.380)$ & (1.961) & $(1.586)$ & $(1.530)$ & $(1.678)$ & $(2.436)$ & $(2.426)$ & $(3.106)$ & $(2.365)$ & $(2.102)$ & (2.479) & (1.529) \\
\hline to $\operatorname{GDP}(-1)$ & $\begin{array}{c}-0.795^{* *} \\
(0.391)\end{array}$ & $\begin{array}{c}-2.118^{\star \star \star} \\
(0.716)\end{array}$ & $\begin{array}{c}-2.928^{* * *} \\
(0.768)\end{array}$ & $\begin{array}{c}-5.540^{* \star *} \\
(1.236)\end{array}$ & $\begin{array}{c}-6.055^{\star \star \star} \\
(1.907)\end{array}$ & $\begin{array}{r}-8.292^{\star \star *} \\
(2.462)\end{array}$ & 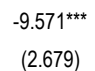 & $\begin{array}{c}-11.508^{* * *} \\
(2.781)\end{array}$ & $\begin{array}{c}-10.008^{* * *} \\
(2.718)\end{array}$ & $\begin{array}{c}-10.274^{* \star *} \\
(2.604)\end{array}$ & $\begin{array}{l}-9.080^{*} \\
(4.696)\end{array}$ & $\begin{array}{c}-8.032^{\star \star} \\
(3.900)\end{array}$ & $\begin{array}{c}-11.236^{* *} \\
(4.467)\end{array}$ & $\begin{array}{c}-11.531^{\star \star * *} \\
(2.382)\end{array}$ & $\begin{array}{c}-13.868^{* \star *} \\
(4.484)\end{array}$ & $\begin{array}{c}-13.504^{* * *} \\
(5.134)\end{array}$ \\
\hline Monetary Policy Shock & -0.238 & -0.679 & -0.652 & -0.070 & 1.404 & 0.324 & 0.597 & -1.215 & -0.640 & -1.229 & 0.005 & -2.068 & -2.398 & -2.389 & -0.999 & 1.011 \\
\hline CRE-Specific & $(0.360)$ & $(0.688)$ & $(0.804)$ & $(1.025)$ & $(1.331)$ & $(1.499)$ & $(1.929)$ & $(1.884)$ & (2.662) & $(1.908)$ & $(2.851)$ & $(2.297)$ & $(2.377)$ & (2.074) & $(3.375)$ & (2.761) \\
\hline Macroprudential Measure & $\begin{array}{c}-0.023 \\
(0.138)\end{array}$ & $\begin{array}{l}-0.032 \\
(0.188)\end{array}$ & $\begin{array}{l}-0.526 \\
(0.436)\end{array}$ & $\begin{array}{l}-0.487 \\
(0.334)\end{array}$ & $\begin{array}{l}-0.324 \\
(0.229)\end{array}$ & $\begin{array}{c}-1.063^{* *} \\
(0.490)\end{array}$ & $\begin{array}{c}-2.781^{* *} \\
(1.313)\end{array}$ & $\begin{array}{l}-3.264^{* *} \\
(1.266)\end{array}$ & $\begin{array}{l}-2.846^{*} \\
(1.603)\end{array}$ & $\begin{array}{l}-2.918^{*} \\
(1.905)\end{array}$ & $\begin{array}{l}-3.301 \\
(2.184)\end{array}$ & $\begin{array}{l}-4.116^{*} \\
(2.301)\end{array}$ & $\begin{array}{l}-4.679^{*} \\
(2.539)\end{array}$ & $\begin{array}{l}-5.045^{* *} \\
(2.546)\end{array}$ & $\begin{array}{l}-4.967^{* *} \\
(2.497)\end{array}$ & $\begin{array}{l}-4.406^{*} \\
(2.286)\end{array}$ \\
\hline $\begin{array}{l}\text { Country FE } \\
\text { CRE price misalignment }\end{array}$ & YES & YES & YES & YES & YES & YES & YES & YES & YES & YES & YES & YES & YES & YES & YES & YES \\
\hline change lag & YES & YES & YES & YES & YES & YES & YES & YES & YES & YES & YES & YES & YES & YES & YES & YES \\
\hline Observations & 691 & 683 & 675 & 664 & 653 & 642 & 631 & 620 & 609 & 598 & 587 & 576 & 565 & 554 & 543 & 532 \\
\hline
\end{tabular}

Note: The tables report the estimated coefficients from the specification described in equation (A4.2.1). The models are estimated using the full sample of core economies. The dependent variable corresponds to the $5^{\text {th }}$ percentile of the change in CRE price misalignment over the forecasting horizon h. CRE-specific measures are defined as a categorical variable taking values $-1,0$, or 1 if there was a loosening action, no change, or a tightening action, respectively, in a quarter. These include borrower-based policies that limit borrowers' access to bank credit, such as CRE-specific loan-to-value (LTV) and debt service-toincome (DSTI) ratios, and capital-based policies that enhance banks' resilience, such as higher risk weights and sectoral capital buffers for CRE exposures. The policy measure is purged of credit-to-GDP ratio to address potential endogeneity. The monetary policy shock is measured by the predicted residual from regressing the policy rate on contemporaneous and lagged variables and a quadratic time trend as in Iacoviello and Navarro (2019). All covariates are standardized so that magnitudes of coefficients indicate relative importance of variables. Standard errors are bootstrapped and shown in parentheses. $* * *$ $\mathrm{p}<0.01,{ }^{* *} \mathrm{p}<0.05,{ }^{*} \mathrm{p}<0.1$ 


\section{A4.3. Effect on Capital Flow Management Measures}

In this part of Annex 4, we examine the association between capital flow management measures and downside risks to CRE prices as follows:

$$
\Delta_{h} Y_{i, t, \tau}=\alpha_{i, \tau}^{h}+\beta_{\tau}^{h} \Delta C F M_{i, t}+\gamma_{\tau}^{h} M P_{i, t}+\theta_{\tau}^{h} \text { Controls }_{i, t-1}+\epsilon_{i, t, \tau}^{h}
$$

where $\Delta C F M_{i, t}$ is the change in capital flow management measures. The capital flow management measure is the overall capital inflow restrictions index or the real-estate-specific capital inflow restriction index from the Fernández and others (2017) database augmented with the most recent policy announcements in the IMF 2020 Taxonomy of Capital Flow Management Measures. The indices are based on a two-year rolling sum of individual measures (with $+1=$ tightening, $0=$ no change, $-1=$ loosening) and purged from variation in capital flow-to-GDP.

The analysis looks at the effect of restrictions on capital flows, captured through an overall index of capital inflow restrictiveness (Figure A4.3.1, panel 1), as well as through a restrictiveness index specific to CRE capital inflows (where the sample comprises advanced economies only, given that as such measures have generally been applied in these economies) (Figure A4.3.1, panel 2). The results show that such measures are also associated with a reduction of downside risks in CRE prices.

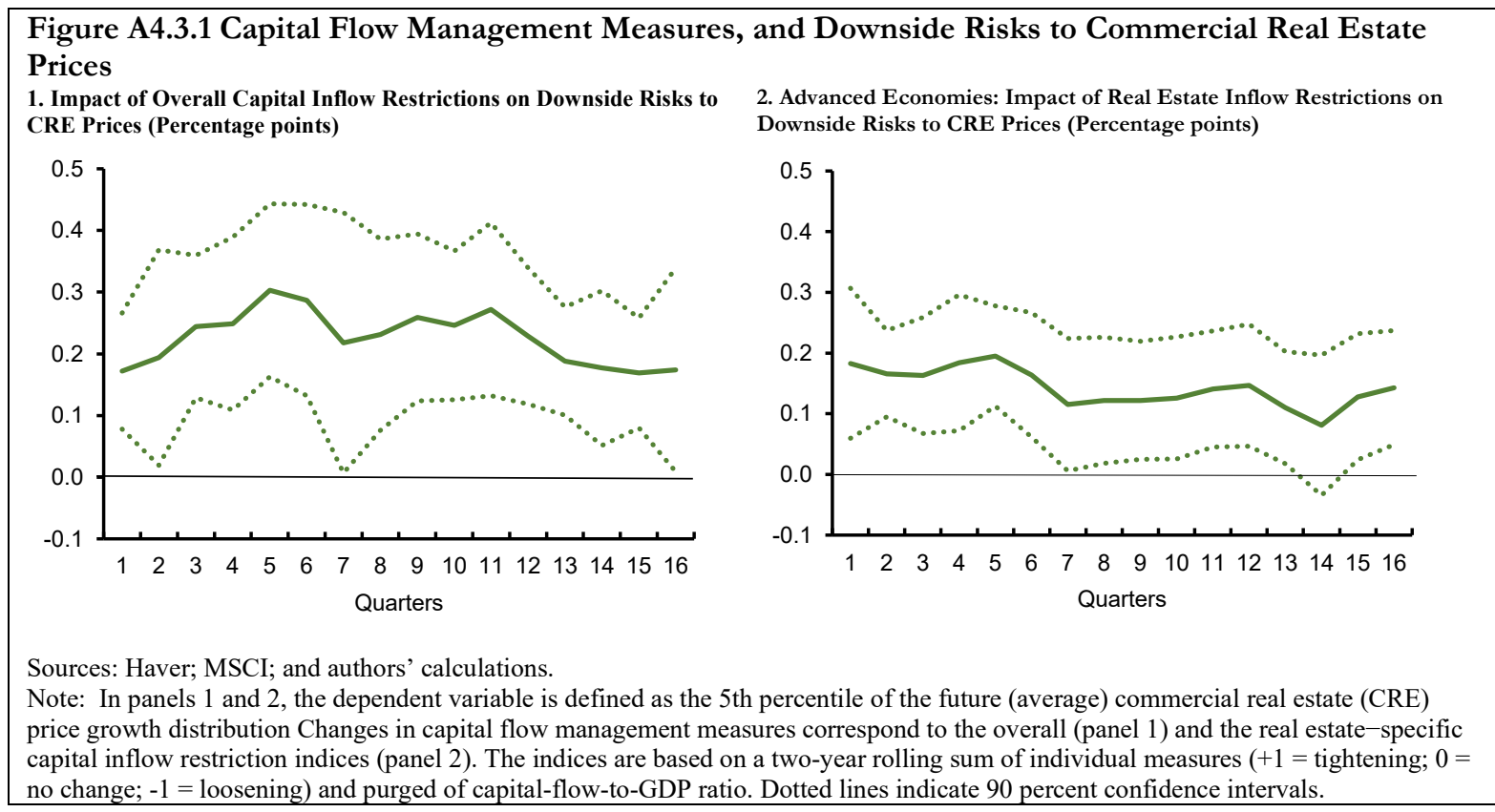


Table 4.3.1. Effect of CFM Overall Inflow Restriction Shock on CRE Prices-at-Risk

\begin{tabular}{|c|c|c|c|c|c|c|c|c|c|c|c|c|c|c|c|c|}
\hline VARIABLES & $h=1$ & $h=2$ & $h=3$ & $h=4$ & $h=5$ & $h=6$ & $h=7$ & $h=8$ & $h=9$ & $h=10$ & $h=11$ & $h=12$ & $h=13$ & $h=14$ & $h=15$ & $h=16$ \\
\hline \multirow[t]{2}{*}{ GDP growth (-1) } & 0.129 & 0.047 & 0.176 & 0.162 & 0.140 & 0.133 & 0.141 & 0.126 & 0.151 & 0.152 & 0.151 & 0.154 & 0.156 & 0.155 & $0.184^{*}$ & $0.172^{\star *}$ \\
\hline & $(0.157)$ & $(0.173)$ & $(0.130)$ & $(0.121)$ & $(0.134)$ & $(0.146)$ & $(0.140)$ & $(0.185)$ & $(0.174)$ & $(0.150)$ & $(0.120)$ & $(0.142)$ & $(0.122)$ & $(0.167)$ & $(0.101)$ & $(0.074)$ \\
\hline \multirow{2}{*}{ Financial conditions index (-1) } & 0.008 & 0.040 & 0.031 & 0.038 & $0.135^{*}$ & $0.178^{\star \star}$ & $0.178^{*}$ & $0.208^{\star \star}$ & 0.136 & $0.141^{\star \star *}$ & $0.150^{\star \star \star}$ & $0.175^{\star \star}$ & $0.151^{\star \star \star}$ & $0.138^{\star \star \star}$ & $0.092^{\star *}$ & 0.082 \\
\hline & $(0.103)$ & $(0.104)$ & $(0.102)$ & $(0.082)$ & $(0.073)$ & $(0.085)$ & $(0.105)$ & $(0.083)$ & $(0.088)$ & $(0.054)$ & $(0.055)$ & $(0.071)$ & $(0.040)$ & $(0.035)$ & $(0.039)$ & $(0.056)$ \\
\hline \multirow[t]{2}{*}{ Capital Inflow to GDP (-1) } & $-0.418^{\star}$ & $-0.602^{* *}$ & $-0.704^{* \star *}$ & $-0.541^{* \star *}$ & $-0.622^{* * *}$ & $-0.606^{* * *}$ & $-0.565^{\star \star}$ & $-0.606^{* * *}$ & $-0.667^{\star * *}$ & $-0.549^{* *}$ & $-0.505^{\star * *}$ & $-0.573^{* * *}$ & $-0.509^{* * *}$ & $-0.471^{\star \star \star}$ & $-0.513^{* * *}$ & $-0.515^{* \star *}$ \\
\hline & $(0.235)$ & $(0.280)$ & $(0.238)$ & $(0.145)$ & $(0.158)$ & $(0.204)$ & $(0.239)$ & $(0.148)$ & $(0.173)$ & $(0.231)$ & $(0.160)$ & $(0.195)$ & $(0.133)$ & $(0.135)$ & $(0.098)$ & $(0.096)$ \\
\hline \multirow[t]{2}{*}{ Change in Credit-to-GDP (-1) } & $-0.463^{* \star *}$ & $-0.482^{* \star *}$ & $-0.484^{\star \star \star}$ & $-0.462^{\star \star \star}$ & $-0.438^{\star \star \star}$ & $-0.434^{\star \star \star}$ & $-0.376^{\star \star *}$ & $-0.406^{* \star *}$ & $-0.511^{\star \star \star}$ & $-0.464^{\star * *}$ & $-0.428^{\star \star *}$ & $-0.438^{\star \star \star}$ & $-0.435^{\star \star *}$ & $-0.423^{\star \star \star}$ & $-0.484^{\star \star \star}$ & $-0.489^{* \star *}$ \\
\hline & $(0.134)$ & $(0.135)$ & $(0.085)$ & $(0.122)$ & $(0.085)$ & $(0.106)$ & $(0.104)$ & $(0.142)$ & $(0.119)$ & $(0.108)$ & $(0.105)$ & $(0.107)$ & $(0.099)$ & $(0.066)$ & $(0.148)$ & $(0.108)$ \\
\hline \multirow[t]{2}{*}{$\operatorname{VIX}(-1)$} & $-0.590^{* \star *}$ & $-0.776^{* \star *}$ & $-0.597^{\star \star \star}$ & $-0.402^{* \star *}$ & $-0.399^{* \star *}$ & $-0.332^{* *}$ & $-0.260^{*}$ & $-0.341^{\star *}$ & $-0.215^{*}$ & -0.195 & -0.055 & -0.135 & -0.109 & -0.069 & -0.046 & -0.018 \\
\hline & $(0.149)$ & $(0.174)$ & $(0.137)$ & $(0.140)$ & $(0.113)$ & $(0.129)$ & $(0.141)$ & $(0.151)$ & $(0.115)$ & $(0.128)$ & $(0.114)$ & $(0.092)$ & $(0.080)$ & $(0.108)$ & $(0.103)$ & $(0.119)$ \\
\hline \multirow[t]{2}{*}{ Monetary policy shock } & 0.025 & $0.130^{*}$ & 0.128 & 0.068 & 0.092 & 0.094 & 0.052 & -0.002 & 0.003 & -0.021 & 0.020 & -0.004 & 0.028 & 0.049 & $0.101^{*}$ & 0.098 \\
\hline & $(0.090)$ & $(0.074)$ & $(0.084)$ & $(0.086)$ & $(0.077)$ & $(0.064)$ & $(0.125)$ & $(0.119)$ & $(0.123)$ & $(0.085)$ & $(0.073)$ & $(0.096)$ & $(0.088)$ & $(0.093)$ & $(0.052)$ & $(0.088)$ \\
\hline \multirow[t]{2}{*}{ CFM Overall Inflow Restriction Shock } & $0.172^{*}$ & $0.194^{*}$ & $0.244^{\star \star \star}$ & $0.249^{\star \star \star}$ & $0.303^{\star \star *}$ & $0.287^{\star \star *}$ & $0.218^{*}$ & $0.231^{* \star *}$ & $0.259^{\star \star *}$ & $0.246^{\star \star \star}$ & $0.272^{\star \star *}$ & $0.229^{\star \star \star}$ & $0.188^{* *}$ & $0.177^{\star \star}$ & $0.169^{\star \star *}$ & $0.174^{* *}$ \\
\hline & $(0.104)$ & $(0.104)$ & $(0.085)$ & $(0.078)$ & $(0.069)$ & $(0.082)$ & $(0.115)$ & $(0.084)$ & $(0.094)$ & $(0.064)$ & $(0.070)$ & $(0.067)$ & $(0.083)$ & $(0.089)$ & $(0.058)$ & $(0.074)$ \\
\hline Country FE & YES & YES & YES & YES & YES & YES & YES & YES & YES & YES & YES & YES & YES & YES & YES & YES \\
\hline CRE prices growth lag & YES & YES & YES & YES & YES & YES & YES & YES & YES & YES & YES & YES & YES & YES & YES & YES \\
\hline Observations & 1,664 & 1,664 & 1,664 & 1,664 & 1,664 & 1,664 & 1,664 & 1,664 & 1,642 & 1,620 & 1,591 & 1,561 & 1,531 & 1,501 & 1,471 & 1,441 \\
\hline
\end{tabular}

Note: The tables report the estimated coefficients from the extended CRE Price-at-Risk specification described in equation (11). The models are estimated using the full sample of core economies. The dependent variable corresponds to the $5^{\text {th }}$ percentile of the average CRE prices growth distribution over the forecasting horizon $\mathrm{h}$. Capital flow management measures (CFM) overall inflow restriction index used in the specification is based on a two-year rolling sum of individual measures ( $+1=$ tightening; $0=$ no change; $-1=$ loosening) and purged of capital-flow-to-GDP ratio to address potential endogeneity. The monetary policy shock is measured by the predicted residual from regressing the policy rate on contemporaneous and lagged variables and a quadratic time trend as in Iacoviello and Navarro (2019). All covariates are standardized so that magnitudes of coefficients indicate relative importance of variables. Standard errors are bootstrapped and shown in parentheses. $* * * \mathrm{p}<0.01, * *$ $\mathrm{p}<0.05,{ }^{*} \mathrm{p}<0.1$. 
Table 4.3.2. Effect of CFM Real-estate Inflow Restriction Shock on CRE Prices-at-Risk

\begin{tabular}{|c|c|c|c|c|c|c|c|c|c|c|c|c|c|c|c|c|}
\hline VARIABLES & $\mathrm{h}=1$ & $h=2$ & $h=3$ & $h=4$ & $h=5$ & $h=6$ & $h=7$ & $h=8$ & $h=9$ & $h=10$ & $h=11$ & $h=12$ & $h=13$ & $h=14$ & $h=15$ & $h=16$ \\
\hline GDP growth (-1) & $\begin{array}{c}0.293 \\
(0.186)\end{array}$ & $\begin{array}{c}0.193 \\
(0.257)\end{array}$ & $\begin{array}{c}0.320 \\
(0.234)\end{array}$ & $\begin{array}{c}0.279 \\
(0.239)\end{array}$ & $\begin{array}{c}0.189 \\
(0.255)\end{array}$ & $\begin{array}{c}0.052 \\
(0.245)\end{array}$ & $\begin{array}{c}0.102 \\
(0.209)\end{array}$ & $\begin{array}{c}0.041 \\
(0.242)\end{array}$ & $\begin{array}{c}0.155 \\
(0.211)\end{array}$ & $\begin{array}{c}0.113 \\
(0.231)\end{array}$ & $\begin{array}{c}0.074 \\
(0.127)\end{array}$ & $\begin{array}{c}0.058 \\
(0.208)\end{array}$ & $\begin{array}{c}0.058 \\
(0.171)\end{array}$ & $\begin{array}{c}0.051 \\
(0.208)\end{array}$ & $\begin{array}{c}0.037 \\
(0.221)\end{array}$ & $\begin{array}{c}0.013 \\
(0.145)\end{array}$ \\
\hline Financial conditions index (-1) & $\begin{array}{c}0.102 \\
(0.109)\end{array}$ & $\begin{array}{c}0.027 \\
(0.161)\end{array}$ & $\begin{array}{c}0.107 \\
(0.158)\end{array}$ & $\begin{array}{c}0.148 \\
(0.106)\end{array}$ & $\begin{array}{c}0.116 \\
(0.079)\end{array}$ & $\begin{array}{c}0.145 \\
(0.100)\end{array}$ & $\begin{array}{c}0.116 \\
(0.109)\end{array}$ & $\begin{array}{l}0.152^{*} \\
(0.078)\end{array}$ & $\begin{array}{l}0.133^{*} \\
(0.079)\end{array}$ & $\begin{array}{c}0.112 \\
(0.090)\end{array}$ & $\begin{array}{l}0.131^{\star *} \\
(0.052)\end{array}$ & $\begin{array}{l}0.117^{\star} \\
(0.064)\end{array}$ & $\begin{array}{l}0.120^{* *} \\
(0.056)\end{array}$ & $\begin{array}{l}0.118^{*} \\
(0.066)\end{array}$ & $\begin{array}{c}0.084 \\
(0.080)\end{array}$ & $\begin{array}{l}0.080^{*} \\
(0.044)\end{array}$ \\
\hline Capital Inflow to GDP (-1) & $\begin{array}{l}-0.533^{* *} \\
(0.259)\end{array}$ & $\begin{array}{l}-0.641^{\star} \\
(0.346)\end{array}$ & $\begin{array}{c}-0.729^{\star * *} \\
(0.244)\end{array}$ & $\begin{array}{c}-0.698^{\star *} \\
(0.307)\end{array}$ & $\begin{array}{c}-0.814^{\star * *} \\
(0.206)\end{array}$ & $\begin{array}{c}-0.721^{\star \star *} \\
(0.189)\end{array}$ & $\begin{array}{c}-0.703^{* * \star} \\
(0.203)\end{array}$ & $\begin{array}{c}-0.683^{* \star *} \\
(0.222)\end{array}$ & $\begin{array}{c}-0.706^{\star \star \star} \\
(0.208)\end{array}$ & $\begin{array}{c}-0.677^{\star * *} \\
(0.207)\end{array}$ & $\begin{array}{c}-0.706^{* * *} \\
(0.161)\end{array}$ & $\begin{array}{c}-0.649^{* * *} \\
(0.195)\end{array}$ & $\begin{array}{c}-0.588^{\star * *} \\
(0.205)\end{array}$ & $\begin{array}{c}-0.565^{\star \star \star} \\
(0.141)\end{array}$ & $\begin{array}{c}-0.540^{* \star *} \\
(0.143)\end{array}$ & $\begin{array}{c}-0.497^{* * \star} \\
(0.140)\end{array}$ \\
\hline Change in Credit-to-GDP (-1) & $\begin{array}{c}-0.518^{* \star *} \\
(0.126)\end{array}$ & $\begin{array}{c}-0.468^{* * *} \\
(0.173)\end{array}$ & $\begin{array}{c}-0.539^{* * *} \\
(0.093)\end{array}$ & $\begin{array}{c}-0.450^{* * *} \\
(0.139)\end{array}$ & $\begin{array}{c}-0.485^{\star \star *} \\
(0.159)\end{array}$ & $\begin{array}{c}-0.492^{* \star *} \\
(0.141)\end{array}$ & $\begin{array}{c}-0.526^{* * *} \\
(0.124)\end{array}$ & $\begin{array}{c}-0.541^{\star \star *} \\
(0.158)\end{array}$ & $\begin{array}{c}-0.571^{\star \star \star} \\
(0.113)\end{array}$ & $\begin{array}{c}-0.577^{\star \star *} \\
(0.127)\end{array}$ & $\begin{array}{c}-0.587^{\star \star \star} \\
(0.108)\end{array}$ & $\begin{array}{c}-0.565^{\star \star \star} \\
(0.113)\end{array}$ & $\begin{array}{c}-0.547^{\star \star \star} \\
(0.146)\end{array}$ & $\begin{array}{c}-0.533^{\star \star *} \\
(0.062)\end{array}$ & $\begin{array}{c}-0.510^{\star \star *} \\
(0.108)\end{array}$ & $\begin{array}{c}-0.500^{* \star *} \\
(0.105)\end{array}$ \\
\hline $\operatorname{VIX}(-1)$ & $\begin{array}{c}-0.572^{\star * *} \\
(0.121)\end{array}$ & $\begin{array}{c}-0.843^{* * *} \\
(0.135)\end{array}$ & $\begin{array}{c}-0.731^{\star * *} \\
(0.191)\end{array}$ & $\begin{array}{c}-0.507^{* * *} \\
(0.182)\end{array}$ & $\begin{array}{c}-0.455^{* \star *} \\
(0.131)\end{array}$ & $\begin{array}{c}-0.407^{* *} \\
(0.189)\end{array}$ & $\begin{array}{c}-0.329^{*} \\
(0.171)\end{array}$ & $\begin{array}{c}-0.361^{* * *} \\
(0.115)\end{array}$ & $\begin{array}{l}-0.278^{*} \\
(0.155)\end{array}$ & $\begin{array}{l}-0.189 \\
(0.146)\end{array}$ & $\begin{array}{l}-0.163 \\
(0.115)\end{array}$ & $\begin{array}{l}-0.114 \\
(0.136)\end{array}$ & $\begin{array}{l}-0.104 \\
(0.132)\end{array}$ & $\begin{array}{l}-0.113 \\
(0.095)\end{array}$ & $\begin{array}{l}-0.006 \\
(0.150)\end{array}$ & $\begin{array}{c}0.091 \\
(0.060)\end{array}$ \\
\hline MP Shock & $\begin{array}{c}0.110 \\
(0.128)\end{array}$ & $\begin{array}{c}0.133 \\
(0.113)\end{array}$ & $\begin{array}{c}0.184 \\
(0.148)\end{array}$ & $\begin{array}{c}0.083 \\
(0.171)\end{array}$ & $\begin{array}{c}0.079 \\
(0.102)\end{array}$ & $\begin{array}{l}-0.025 \\
(0.183)\end{array}$ & $\begin{array}{l}-0.007 \\
(0.173)\end{array}$ & $\begin{array}{l}-0.042 \\
(0.168)\end{array}$ & $\begin{array}{l}-0.033 \\
(0.166)\end{array}$ & $\begin{array}{l}-0.026 \\
(0.113)\end{array}$ & $\begin{array}{l}-0.004 \\
(0.079)\end{array}$ & $\begin{array}{c}0.023 \\
(0.120)\end{array}$ & $\begin{array}{c}0.016 \\
(0.111)\end{array}$ & $\begin{array}{c}0.013 \\
(0.080)\end{array}$ & $\begin{array}{c}0.003 \\
(0.144)\end{array}$ & $\begin{array}{c}0.010 \\
(0.079)\end{array}$ \\
\hline $\begin{array}{l}\text { CFM real estate inflow } \\
\text { restriction shock }\end{array}$ & $\begin{array}{c}0.183^{\star \star \star} \\
(0.059)\end{array}$ & $\begin{array}{c}0.166^{\star \star *} \\
(0.037)\end{array}$ & $\begin{array}{c}0.163 \\
(0.105)\end{array}$ & $\begin{array}{l}0.184^{* *} \\
(0.081)\end{array}$ & $\begin{array}{c}0.195^{\star * *} \\
(0.049)\end{array}$ & $\begin{array}{c}0.164^{\star * \star} \\
(0.057)\end{array}$ & $\begin{array}{l}0.115 \\
(0.089)\end{array}$ & $\begin{array}{l}0.122^{\star *} \\
(0.061)\end{array}$ & $\begin{array}{l}0.122 \\
(0.075)\end{array}$ & $\begin{array}{l}0.126^{\star *} \\
(0.050)\end{array}$ & $\begin{array}{l}0.141^{*} \\
(0.071)\end{array}$ & $\begin{array}{c}0.147^{\star \star *} \\
(0.050)\end{array}$ & $\begin{array}{l}0.110^{\star *} \\
(0.048)\end{array}$ & $\begin{array}{l}0.081^{*} \\
(0.045)\end{array}$ & $\begin{array}{l}0.128^{\star *} \\
(0.055)\end{array}$ & $\begin{array}{l}0.143^{* *} \\
(0.067)\end{array}$ \\
\hline Country FE & YES & YES & YES & YES & YES & YES & YES & YES & YES & YES & YES & YES & YES & YES & YES & YES \\
\hline CRE prices growth lag & YES & YES & YES & YES & YES & YES & YES & YES & YES & YES & YES & YES & YES & YES & YES & YES \\
\hline Observations & 1,346 & 1,346 & 1,346 & 1,346 & 1,346 & 1,346 & 1,346 & 1,346 & 1,331 & 1,316 & 1,294 & 1,271 & 1,248 & 1,225 & 1,202 & 1,179 \\
\hline
\end{tabular}

Note: The tables report the estimated coefficients from the extended CRE Price-at-Risk specification described in equation (11). The models are estimated using the full sample of core economies. The dependent variable corresponds to the $5^{\text {th }}$ percentile of the average CRE prices growth distribution over the forecasting horizon h. Capital flow management measures (CFM) real estate inflow restriction index used in the specification is based on a two-year rolling sum of individual measures $(+1=$ tightening; $0=$ no change; $-1=1$ loosening) and purged of capital-flow-to-GDP ratio to address potentia endogeneity. The monetary policy shock is measured by the predicted residual from regressing the policy rate on contemporaneous and lagged variables and a quadratic time trend as in Iacoviello and Navarro (2019). All covariates are standardized so that magnitudes of coefficients indicate relative importance of variables. Standard errors are bootstrapped and shown in parentheses. $* * * \mathrm{p}<0.01, * *$ $\mathrm{p}<0.05, * \mathrm{p}<0.1$. 